HYDROGEOLOGY, DEGRADATION OF GROUND-WATER QUALITY, AND

SIMULATION OF INFILTRATION FROM THE DELAWARE RIVER

INTO THE POTOMAC AQUIFERS, NORTHERN DELAWARE

By Scott W. Phillips

U.S . GEOLOGICAL SURVEY

Water-Resources Investigations Report 87-4185

Prepared in cooperation with the

DELAWARE DEPARTMENT OF NATURAL RESOURCES

AND ENVIRONMENTAL CONTROL

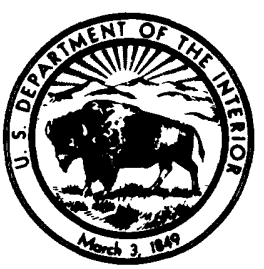

Towson, Maryland 
DEPARTMENT OF THE INTERIOR

DONALD PAUL HODEL, Secretary

U.S. GEOLOGICAL SURVEY

Dallas L. Peck, Director

For additional information write to:

District Chief U.S. Geological Survey 208 Carroll Building 8600 La Salle Road Towson, Maryland 21204
Copies of this report can be purchased from:

Books and Open-File Reports Section U.S. Geological Survey Box 25425, Federal Center, Bldg. 810 Denver, Colorado 80225 


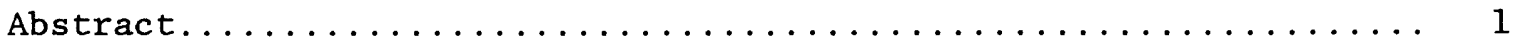

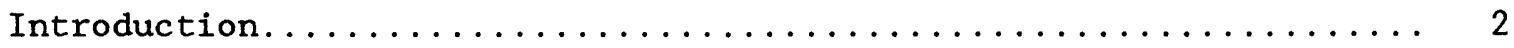

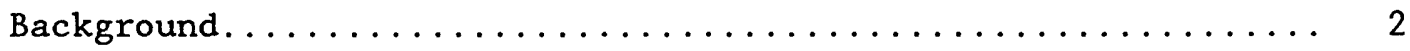

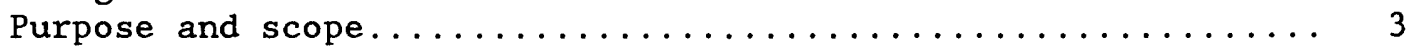

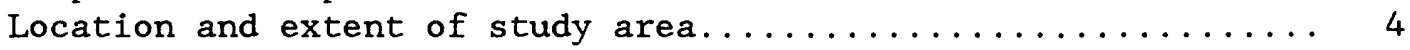

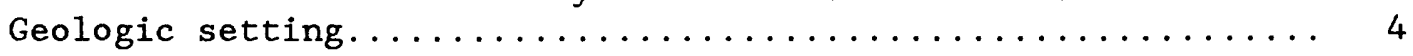

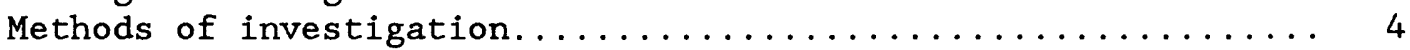

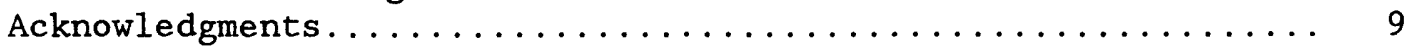

Hydrogeology .................................. 10

Aquifers and confining units......................... 10

Potomac aquifers........................... 10

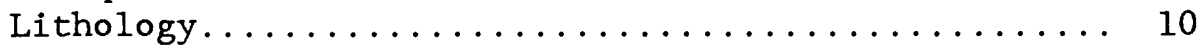

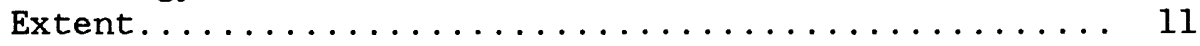

Hydraulic properties.................. 19

Upper Potomac confining unit.................... 19

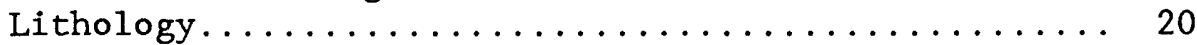

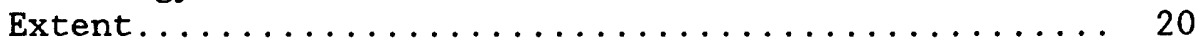

Hydraulic properties..................... 21

Columbia Aquifer and Holocene sediments............ 21

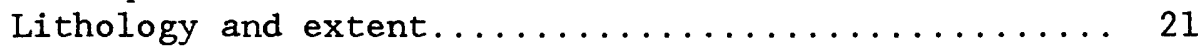

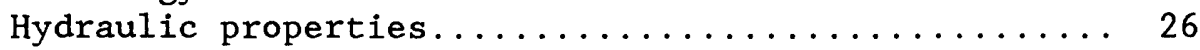

Hydrologic significance of Pleistocene erosion........... 26

Source and movement of ground water................ 29

Quality of ground water and Delaware River............. 32

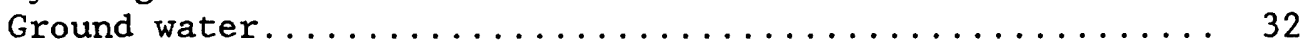

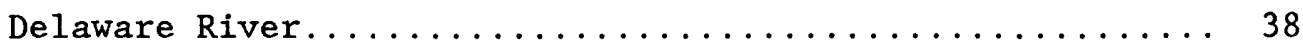

Degradation of ground-water quality in the Potomac aquifers...... 40

Llangollen Estates--Crown Films--Amoco well fields......... 42

New Castle well field........................... 48

Collins Park--ICI Americas well fields................ 51

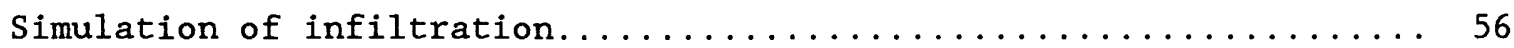

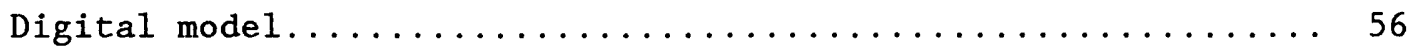

Conversion to the modular model............... 56

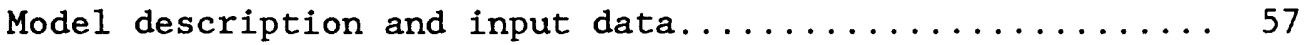

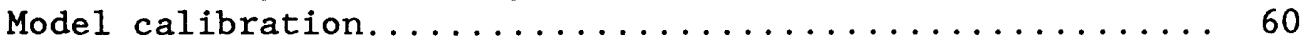

Effects of hypothetical pumpage scenarios............... 61

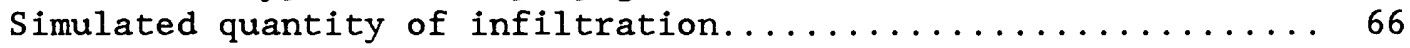

Simulated effect of freshwater-injection barriers........... 78

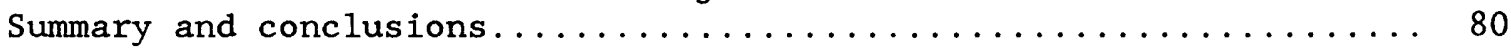

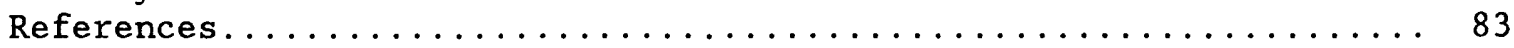


Figure 1. Map showing location of study area and model area with well fields................ 5

2. Map showing location of data points and hydrogeologic sections.................. 7

3-8. Hydrogeologic sections

3. A-A', Red Lion Creek.................. 12

4. B-B', Artisans Village to Crown Films......... 14

5. C-C', Crown Films to New Jersey............ 15

6. D-D', New Castle..................... 16

7. E-E', New Castle to Delaware Memorial Bridge.... 17

8. F-F', Collins Park to Delaware Memorial Bridge.. 18

9. Map showing altitude of the base of the Columbia

Group, undifferentiated.................. 24

10. Map showing thickness of the Holocene silt......... 25

11. Map showing areal distribution of the base of the Columbia Group, undifferentiated, below sea level and Holocene silt less than 40 feet thick..........

12. Diagrams showing the generalized hydrogeologic framework of the Columbia aquifer, upper confining unit, Potomac aquifer, and underlying confining unit beneath the

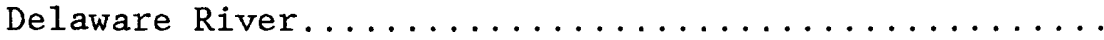

13-14. Maps showing the potentiometric surface during May 1985 for the

13. Upper Potomac aquifer............... 30

14. Middle Potomac aquifer.............. 31

15. Map showing chloride concentrations and Stiff diagrams in the uppermost Potomac aquifer

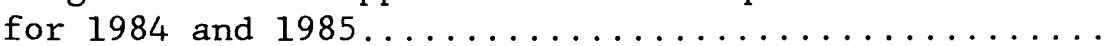

16. Durov diagram showing plots of water-quality analyses..

17. Map showing location of waste-disposal sites and well fields affected by infiltration of river water

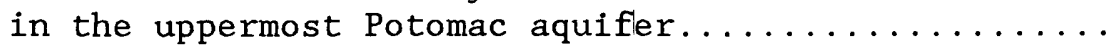

18. Graph showing change in chloride concentrations over time in the Delaware River at the Delaware Memorial

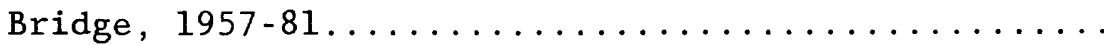


Figure 19. Map showing location of wells in the upper Potomac aquifer and April 1985 isochlors for the Llangollen Estates, Army Creek, Amoco, and Crown Films well fields.

20-21. Graphs showing changes in chloride concentrations over time for wells in the upper Potomac aquifer for

20. Dc25-2 and Dc25-27 at the Crown Films well field, $1937-85 \ldots \ldots \ldots \ldots \ldots \ldots \ldots$

21. Dc24-18 at the Llangollen Estates well field $1974-85 \ldots \ldots \ldots \ldots \ldots \ldots \ldots \ldots \ldots . \ldots \ldots$

22. Map showing location of selected wells in the middle Potomac and Columbia aquifers, at the New Castle well field..............................

23. Graph showing change in chloride concentrations over time in wells Cd52-13 and Cd52-27 in the middle Potomac aquifer, at the New Castle well field, 1952-85..... 50

24. Map showing location of production wells in the middle Potomac and Columbia aquifers, at Collins Park and ICI Americas well fields.........................

25-26. Graphs showing change in chloride concentrations over time in wells in the middle Potomac aquifer for

25. Cd43-5, Cd43-4, Cd43-3, Cd43-11 at the ICI Americas well field, $1954-85 \ldots \ldots \ldots \ldots 54$ 26. Cd42-15 and Cd42-17 at the Collins Park well field, $1973-85 \ldots \ldots \ldots \ldots \ldots \ldots \ldots \ldots$

27. Generalized hydrogeologic section and schematic representation of model layers and boundaries....... 58

28. Map showing location of study area and mode1

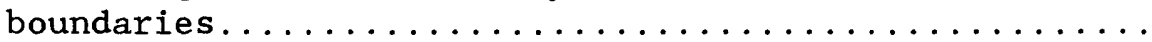

29-30. Maps showing simulated potentiometric surface for scenario 1 for

29. Upper Potomac aquifer, 1985 conditions........6 62

30. Middle Potomac aquifer, 1985 conditions........66 63 


\section{ILLUSTRATIONS - - Continued}

Figure

31-34. Maps showing changes in head in the upper Potomac aquifer for

31. Scenario 2--addition to scenario 1 of pumpage at Artisans Village well field............. 65

32. Scenario 3--addition to scenario 2 of pumpage at Artisans Village and Llangollen Estates well fields, and elimination of Army Creek well field....................... 6

33. Scenario 4--addition to scenario 3 of recovery well at Tybouts Corner landfill........... 68

34. Scenario 5--(combination of scenarios 3 and 4)...669

35-36. Maps showing area of simulated infiltration of river water into the upper Potomac aquifer near the Artisans Village, Llangollen Estates, and Crown Films well fields for

35. Steady-state calibration run (1980) and

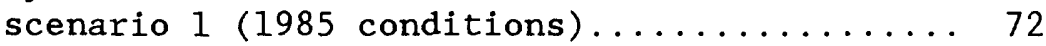

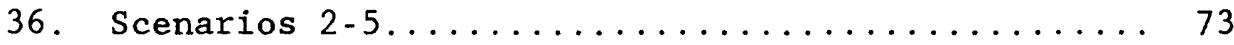

37. Map showing leakance of confining unit overlying the upper Potomac aquifer.................. 74

38. Map showing area of simulated infiltration of river water into the middle Potomac aquifer near the New Castle, Castle Hills, Jefferson Farms, Collins Park, and ICI Americas well fields for the steady-state calibration run (1980) and scenario 1 (1985 conditions)........76

39. Map showing leakance of confining unit overlying the

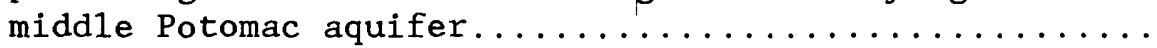

40-41. Maps showing simulated potentiometric surface resulting from injection wells in the

40. Upper Potomac aquifer, 1985 conditions......... 79

41. Middle Potomac aquifer, 1985 conditions........ 81 
Tables

Page

Table 1. Generalized stratigraphy in the study area........... 6

2. Vertical hydraulic conductivities and pore-water chloride concentrations for the Potomac and

Holocene sediments....................... 22

3. Water-quality analyses for selected we1ls in

New Castle County, Delaware................... 36

4. Chloride concentrations and screened intervals in wells of the Columbia aquifer at the ICI Americas well field,

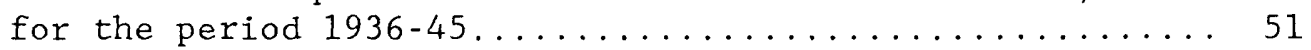

5. Location of wells and pumping rates used in simulated pumpage scenarios....................... 64

6. Amount of infiltration of river water and well-field pumpage for simulated pumpage scenarios................. 71

\section{CONVERSION FACTORS AND ABBREVIATIONS}

For the convenience of readers who may prefer to use metric (International System) units rather than the inch-pound units used in this report, values may be converted by using the following factors:

\section{Multiply inch-pound unit}

foot $(\mathrm{ft})$

foot per second ( $\mathrm{ft} / \mathrm{s}$ )

foot squared per day $(\mathrm{ft} / \mathrm{d})$

gallon per minute (gal/min)

million gallons per day $(\mathrm{Mgal} / \mathrm{d})$

$\operatorname{mile}(\mathrm{mi})$

square mile $\left(\mathrm{mi}^{2}\right)$ by

0.3048

0.3048

0.09290

0.06309

0.04381

1.609

2.590
To obtain metric unit

meter ( $\mathrm{m})$

meter per second (m/s)

meter squared per day $\left(\mathrm{m}^{2} / \mathrm{d}\right)$

cubic meter per second $\left(\mathrm{m}^{3} / \mathrm{s}\right)$

cubic meter per day $\left(\mathrm{m}^{3} / \mathrm{d}\right)$

kilometer $(\mathrm{km})$

square kilometer $\left(\mathrm{km}^{2}\right)$ 
Sea Leve1: In this report, "sea level" refers to the National Geodetic Vertical Datum of 1929 (NGVD of 1929)--a geodetic datum derived from a general adjustment of the first-order level nets of both the United States and Canada, formerly called "Mean Sea Level of 1929."

Chemical concentration in water is expressed in milligrams per liter (mg/L) or micrograms per liter (ug/L).

Specific electrical conductance of water is expressed in microsiemens per centimeter at $25^{\circ} \mathrm{C}(\mathrm{uS} / \mathrm{cm})$. This unit is identical to micromhos per centimeter at $25^{\circ} \mathrm{C}$, formerly used by the U.S. Geological Survey. 


\title{
HYDROGEOLOGY, DEGRADATION OF GROUND-WATER QUALITY, AND \\ SIMULATION OF INFILTRATION FROM THE DELAWARE RIVER
}

INTO THE POTOMAC AQUIFERS, NORTHERN DELAWARE

By Scott W. Phillips

\begin{abstract}
Brackish water is infiltrating from the Delaware River into the underlying Potomac aquifers in the Cretaceous Potomac Formation in northern Delaware. Three Potomac aquifers--the upper, middle, and lower--underlie the river and surrounding areas. The lower Potomac aquifer underlies the river in the northern part of the study area and the middle and upper Potomac aquifers underlie the river to the south. The potential for infiltration of river water into the Potomac aquifers is suggested by groundwater levels below sea level and removal by erosion of confining units overlying the aquifers near the river. Evidence that infiltration at the river is actually occurring includes chloride concentrations in the aquifers that are above ambient levels and chemical characteristics of ground water and river water that are similar.

Pumping from wells has lowered heads in the Potomac aquifers below sea level, which has created a hydraulic gradient from the Delaware River towards the underlying aquifers. In the vicinity of the Delaware River, the Potomac aquifers are overlain by a confining unit that consists of Potomac clay and silt, which acts as a barrier to the infiltration of river water. The downcutting of river channels during Pleistocene time resulted in partial erosion of the confining unit. The channel-fill sediment deposited after the erosional episodes consisted of sand, gravel, and silt. These sediments have a greater permeability than the Potomac confining unit; thus, these paleochannels are potential conduits for the infiltration of river water into the Potomac aquifers.
\end{abstract}

Water quality within the Potomac aquifers has been degraded by the infiltration of river water and by leachate from waste-disposal sites. The ambient ground water has chloride concentrations from 10 to $21 \mathrm{mg} / \mathrm{L}$ (milligrams per liter). Chemical analyses indicate that the ambient ground water is a sodium magnesium calcium-chloride sulfate bicarbonate type. Areas of the Potomac aquifers that have been degraded have chloride concentrations from 40 to $8,600 \mathrm{~m} / \mathrm{L}$, with specific conductances of 200 to 27,200 microsiemens per centimeter at $25^{\circ}$ Celsius. Chemical analyses indicate the ground water in these areas is a sodium-chloride type. The sources of degradation were differentiated by using plots of major ion distributions, concentrations as a function of time, and geochemical plots including Stiff and Durov diagrams. 
Ground-water degradation by the infiltration of river water is occurring in the upper Potomac aquifer at the Llangollen Estates, Crown Films, and Amoco well fields. In 1985, chloride concentrations from the infiltration of river water ranged from 40 to $98 \mathrm{mg} / \mathrm{L}$ in these well fields. Well fields affected by infiltration in the middle Potomac aquifer include New Castle, Collins Park, and ICI Americas. Ground water had chloride concentrations from 61 to $207 \mathrm{mg} / \mathrm{L}$ in 1984 and 1985. Two wells in the lower Potomac aquifer near the Wilmington Marine Terminal also have been affected by the infiltration of river water. Leachate from waste-disposal sites has caused localized ground-water degradation in all three Potomac aquifers, especially north of the Delaware Memorial Bridge and at sites near Army Creek and Red Lion Creek. Chloride concentrations up to $8,600 \mathrm{mg} / \mathrm{L}$ have resulted from waste-disposal leachate.

A ground-water flow model of the Potomac aquifers was used to evaluate aquifer response to five pumpage scenarios, quantify the amount of infiltration of river water for each scenario, and simulate the effectiveness of using freshwater injection barriers to protect the aquifers. Scenario 1 simulated 1985 pumping conditions. Simulated water levels in the upper Potomac aquifer were from 25 to 45 feet below sea level in well fields near the Delaware River. Simulated water levels in the middle Potomac aquifer were as low as 50 feet below sea level in well fields near the river. Heads from scenario 1 were used as starting heads for scenarios 2 through 5 . Additional pumpage at selected well fields was simulated and the effects were represented as drawdowns.

Simulated infiltration of river water into the Potomac aquifers accounts for approximately 6 to 12 percent of the total aquifer recharge in the area of influence of the pumping. There is a direct correlation between the rate of infiltration of river water and the total well-field pumpage. The rate of infiltration of river water for the pumping scenarios ranged from 0.31 to 0.62 million gallons per a day. Simulations of freshwater injection demonstrated that 12 barrier wells, each injecting $300 \mathrm{gal} / \mathrm{min}$ (gallons per minute), would be needed to create a barrier against the infiltration of river water in the upper Potomac aquifer, whereas the middle Potomac aquifer would require 7 wells injecting $200 \mathrm{gal} / \mathrm{min}$.

\section{INTRODUCTION}

\section{Background}

The Potomac aquifers in the Cretaceous Potomac Formation in New Castle County, Del., supply potable water for industrial, municipal, and domestic users. The amount of water withdrawn from 1980 to 1984 was approximately 20 Mgal/d (million gallons per day) (Andrea Putscher, Delaware Department of Natural Resources and Environmental Control, written commun., 1986). Since the mid-1950's, withdrawals from wells located along the Delaware River have caused water levels in the aquifers to fall below sea level. In the reach of the Delaware River located in the study area, the water quality ranges from fresh to brackish because of tidal influences and seasonal variations in freshwater inflow to the river. Consequently during the brackish-water periods, water infiltrating from the river into the Potomac aquifers 
increases chloride and sodium concentrations that degrade ground-water quality. The U.S. Environmental Protection Agency (1976) set a secondary standard (nonhealth related) for drinking water of $250 \mathrm{mg} / \mathrm{L}$ (milligrams per liter) for chloride. Although no standard has been established for sodium concentrations, public water suppliers are required to notify health professionals when sodium concentrations exceed $20 \mathrm{mg} / \mathrm{L}$ in order to advise persons on sodium restricted diets ( $R$. B. Howe11, Delaware Department of Public Health, written commun., 1986).

There is concern that continued or increased pumpage from the Potomac aquifers will increase the infiltration of river water, making the water unsuitable for public consumption. The relation between infiltration of river water and ground-water withdrawals previously was recognized by several State and Federal agencies. In 1974, the Delaware Department of Natural Resources and Environmental Control (DNREC) began to collect waterquality and water-level data from wells in the Potomac aquifers near the Delaware River (Michael Apgar, Delaware Department of Natural Resources and Environmental Control, written commun., 1985). In 1978, the DNREC, U.S. Army Corps of Engineers (COE), and U.S. Geological Survey began a cooperative study to evaluate the effects of pumpage from the Potomac aquifers (Martin, 1984). A study to evaluate the water-supply potential of aquifers in northern Delaware and southern New Jersey was prepared for the Delaware River Basin Commission in 1982 (Camp, Dresser, and McKee, 1982). The study recommended a reduction of ground-water withdrawals in northern Delaware because of the threat of intrusion of brackish water from the Delaware River. In 1984, the U.S. Geological Survey, in cooperation with the DNREC, began an investigation to document the infiltratiaon of brackish water from the Delaware River into the Potomac aquifers in northern Delaware.

\section{Purpose and Scope}

The purpose of this report is to (1) describe the hydrogeologic system in the vicinity of the Delaware River; (2) document the water quality of the Potomac aquifers and Delaware River; (3) characterize the effects of infiltration of river water on the water quality of the Potomac aquifers; and (4) present the results of flow-model simulations that estimate the aquifer response to current and projected ground-water withdrawals, amounts of infiltration of river water, and use of hypothetical injection barriers to prevent infiltration.

Geologic and hydrologic data were collected and analyzed to refine the hydrogeologic system in the study area. The data included geophysical and drillers' logs, core samples, water-level measurements, and pumpage records. Water-quality data were collected and examined to detect evidence of brackish-water intrusion into the aquifers. A quasi three-dimensional digital flow model from the previous U.S. Geological Survey study (Martin, 1984) was converted to the format of the U.S. Geological Survey modular model (McDonald and Harbaugh, 1983) to estimate aquifer response to groundwater stresses. Simulated inflow at model cells in the vicinity of the river were analyzed to estimate the amounts of simulated river-water infiltration into the aquifers. 
The study area occupies about $40 \mathrm{mi}^{2}$ (square miles) in northern New Castle County, Del. (fig. 1). The principal area of interest is between the Fall Line to the north and Red Lion Creek to the south where the Potomac aquifers underlie the Delaware River (fig. 2). The study area is approximately bounded by the Delaware-New Jersey State line to the east and U.S. Route 13 to the west. All three Potomac aquifers--the upper, middle, and lower--are present in northern Delaware. The lower Potomac aquifer crops out in the northern part of the study area, but is overlain by the middle and upper Potomac aquifers to the south. This study focused on the uppermost of the three Potomac aquifers in several areas immediately underlying the river.

\section{Geologic Setting}

Northern New Castle County includes two physiographic provinces--the Piedmont and the Atlantic Coastal Plain. The Piedmont province consists of Precambrian and Paleozoic crystalline rocks that crop out in the northern area of the county. These rocks are overlain by sediments of the Atlantic Coastal Plain province south of the Fall Line. The Coastal Plain sediments consist of interbedded sand, silt, and clay that dip and increase in thickness to the southeast.

The generalized stratigraphy of the study area is described in table 1. Deposition of the Coastal Plain sediments over the erosional surface of the Piedmont began in Early Cretaceous time. The accumulation of these nonmarine sediments continued throughout Cretaceous time and were named the Potomac Formation by McGee (1886). There appears to be no record of Tertiary deposition because of periods of nondeposition or erosion. Unconformably overlying the Potomac Formation are Quaternary sediments, which include the Columbia Group, undifferentiated, and Holocene sediments. Some researchers have stated that deposition of sediments formerly considered part of the Columbia Group began in Miocene time and are part of the Pensauken Formation (Owens and Minard, 1979, p. D29).

The source of the Potomac sediments was the uplift and subsequent erosion of the Appalachian Mountains. The source area, depending on climate, topography, and rock type, supplied a predominantly fine-grained detritus (Sundstrom and others, 1967, p. 17-18). Jordan (1962, p. 6) noted that individual beds of sand, silt, and clay generally are restricted in areal extent and thickness. This lithologic variability in both the horizontal and vertical direction has frustrated attempts to stratigraphically subdivide the Potomac Formation; thus, it is considered a single stratigraphic unit in Delaware.

\section{Methods of Investigation}

The hydrogeologic system of the Potomac Formation in the vicinity of the Delaware River was refined by reviewing historical records and collecting additional data. Historical records included well schedules, drillers' logs, geophysical logs, water leve1s, and pumpage data. These data were reviewed to establish an observation well network for obtaining water-level data in the Potomac and Columbia aquifers. Data were obtained for 342 wells 


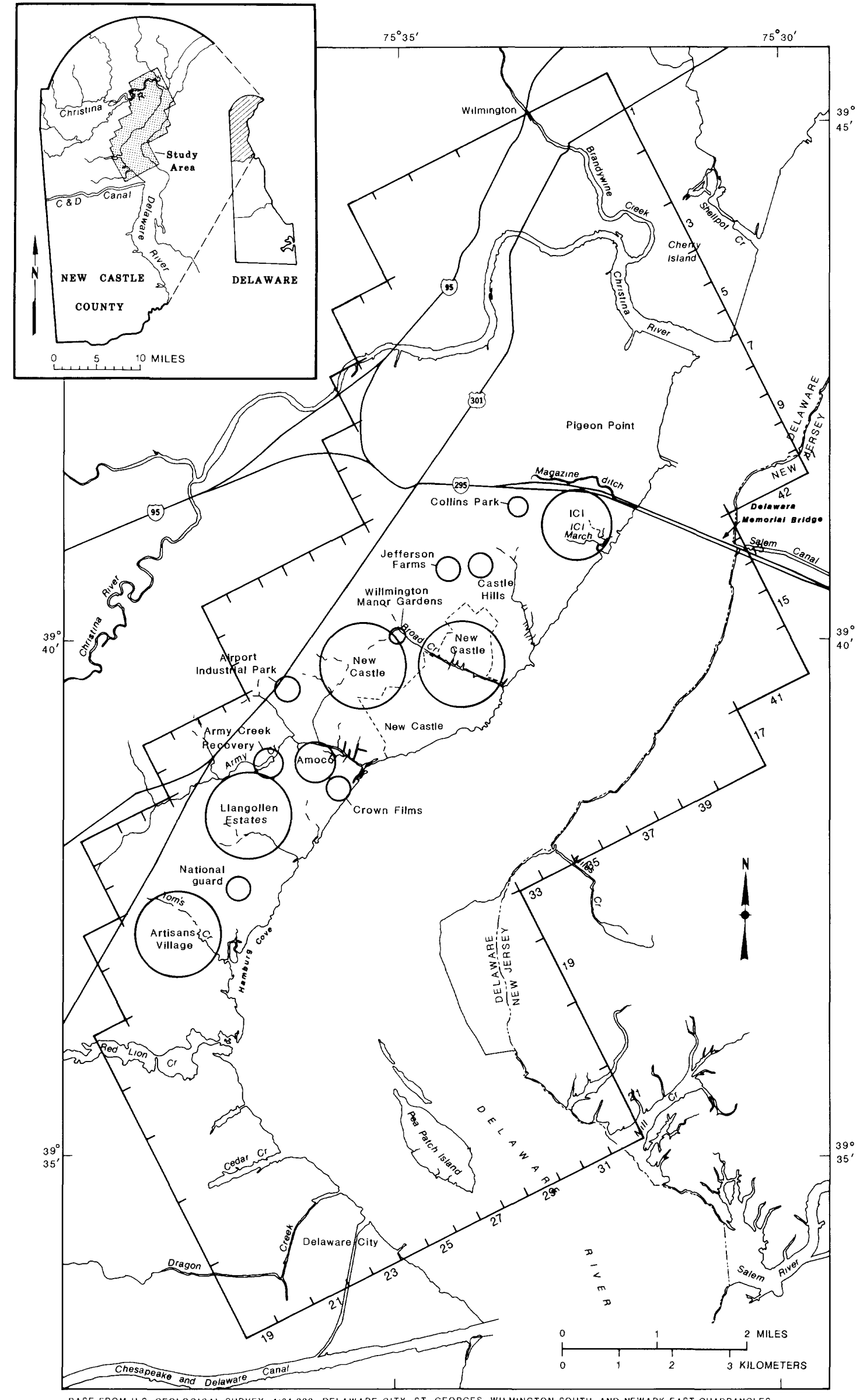

BASE FROM U.S. GEOLOGICAL SURVEY, 1:24,000 DELAWARE CITY, ST. GEORGES, WILMINGTON SOUTH, AND NEWARK EAST QUADRANGLES.

Figure 1. Location of study area and model area with well fields. 
Table 1.--Generalized stratigraphy in the study area

\begin{tabular}{|c|c|c|c|c|}
\hline $\begin{array}{l}\text { System } \\
\text { and erathem }\end{array}$ & Series & Geologic unit & Character & Water-bearing properties \\
\hline \multirow[t]{2}{*}{ Quaternary } & Holocene & $\begin{array}{l}\text { Undifferentiated } \\
\text { deposits }\end{array}$ & $\begin{array}{l}\text { silt, sandy silt, silty } \\
\text { sand, with some gravel; } \\
\text { abundant organics and } \\
\text { some peat beds }\end{array}$ & $\begin{array}{l}\text { Functions as a leaky confining } \\
\text { unit. }\end{array}$ \\
\hline & Pleistocene & $\begin{array}{l}\text { Columbia Group, } \\
\text { undifferentiated }\end{array}$ & $\begin{array}{l}\text { Sand, gravel, with some } \\
\text { clay; predominantly } \\
\text { quartz }\end{array}$ & $\begin{array}{l}\text { Functions as water-table aquifer, } \\
\text { capable of yielding large } \\
\text { quantities of water where } \\
\text { thickness is greater than } 40 \mathrm{ft} \text {. }\end{array}$ \\
\hline Cretaceous & $\begin{array}{l}\text { Upper and } \\
\text { Lower } \\
\text { Cretaceous }\end{array}$ & $\begin{array}{l}\text { Potomac } \\
\text { Formation }\end{array}$ & $\begin{array}{l}\text { silty clays, interbedded } \\
\text { with sands; predominantly } \\
\text { quartz and kaol inite }\end{array}$ & $\begin{array}{l}\text { Sandy zones function as aquifers } \\
\text { in the lower, middle, and } \\
\text { upper parts of formation. }\end{array}$ \\
\hline $\begin{array}{l}\text { Paleozoic } \\
\text { and } \\
\text { Precambrian }\end{array}$ & & $\begin{array}{l}\text { Crystalline } \\
\text { rocks } \\
\text { (Basement) }\end{array}$ & $\begin{array}{l}\text { Complex assemblage of } \\
\text { igneous and } \\
\text { metamorphic rocks }\end{array}$ & $\begin{array}{l}\text { Yields small quantity of water } \\
\text { north of Fall Line. Not an } \\
\text { important water-bearing aquifer } \\
\text { in the Coastal Plain. }\end{array}$ \\
\hline
\end{tabular}

in the study area; of this total, 195 wells were checked to determine their accessibility and condition. The final well network consisted of 87 wells that were measured semiannually. Most of the wells used in the network were assigned a well number in accordance with the well-numbering system used by the Delaware Geological Survey (DGS) (for example, Dc24-41). Wells without an assigned number were identified by a local number (for example, CB247 or TB2).

Four tests holes were drilled by the hydraulic rotary method from a barge in the Delaware River to investigate the hydraulic properties of the sediments underlying the river. Sediment lithologies were determined from drill cuttings, core samples, and geophysical logs. The COE analyzed core samples to determine vertical hydraulic conductivity and pore-water chloride concentrations of the confining units. Additionally, temporary casing was placed in two holes to obtain water-level and water-quality data from the underlying aquifers. Data from the test holes were used in conjunction with historical data in preparing maps of the sediment distribution and potentiometric head of the Potomac aquifers, and hydrogeologic sections.

Surface- and ground-water quality in the study area was documented by sampling selected wells and using data in published and unpublished sources. Water-quality samples were collected during 1984-85. Field parameters measured included $\mathrm{pH}$, temperature, specific conductance, and alkalinity. The samples analyzed by the U.S. Geological survey Central Laboratory in Denver, Colo., were for major ions and selected minor ions including boron, bromide, iodine, potassium, and strontium. Historical water-quality data were obtained from published and unpublished sources. The historical data were used to plot changes in chloride concentrations over time for selected wells, define the water quality of the Delaware River, and characterize the impact of waste-disposal sites. Sources of published historical data include Marine and Rasmussen (1955), Rasmussen and others (1957), Sundstrom and others (1967), Woodruff (1970), Sundstrom and Pickett (1971), and Martin and Denver (1982). Unpublished data were supplied by the DNREC, Delaware Geological Survey, Delaware Department of Health, and various industries and consultants. 
Methods used to interpret the major ion distribution included areal mapping of selected ions, plots of concentration as a function of time, and geochemical plots including Stiff (1951) and Durov (1948) diagrams. Constituent ratios were also analyzed, but proved inconclusive. Areal mapping of constituents helps to identify zones of distinct aquifer water quality. Plotting concentration as a function of time reveals changes or trends in ground-water chemistry. Stiff and Durov diagrams provide a graphical means to represent water-quality analyses.

On Stiff diagrams, the values are plotted as milliequivalents on a horizontal axis extending on each side of a zero vertical axis. Cation concentrations are plotted to the left of zero, while anion concentrations are plotted on the right. The points representing the values are connected to produce a distinctive shape or pattern. The patterns help identify water-quality differences and similarities. The cations plotted are sodium $(\mathrm{Na})$, calcium $(\mathrm{Ca})$, magnesium $(\mathrm{Mg})$, and potassium $(\mathrm{K})$. The anions are chloride $(\mathrm{Cl})$, bicarbonate $\left(\mathrm{HCO}_{3}\right)$ and carbonate $\left(\mathrm{CO}_{3}\right)$, sulfate $\left(\mathrm{SO}_{4}\right)$, and nitrite $\left(\mathrm{NO}_{2}\right)$ plus nitrate $\left(\mathrm{NO}_{3}\right)$.

Zaporozec (1972) used Durov diagrams to plot the relative percentages of cations and anions for a sample. Additionally, two other parameters can be plotted for each analysis. Many analyses are plotted on one Durov diagram, which aids in identification of chemically distinct groups of ground water. This diagram is also used to identify mixing of two different types of water. These groups or types of water are known as hydrochemical facies (Back, 1961, p. 380-382). Hydrochemical facies are distinct zones that have cation and anion concentrations within defined composition categories (Freeze and Cherry, 1979, p. 252).

A calibrated flow model developed during a previous study (Martin, 1984) was used to estimate the response of the aquifer to current pumpage and for one hypothetical pumpage. The model input was reformatted to use in the U.S. Geological Survey modular model (McDonald and Harbaugh, 1983). The model was used to estimate water-level changes resulting from five pumpage scenarios and to evaluate the potential effects of a freshwater injection barrier. Areas and amounts of infiltration from the river were analyzed by studying the flow budgets of the model cells. The pumpage scenarios were designed by DNREC to assist them in formulating water-management decisions.

\section{Acknowledgments}

The author wishes to thank Andrea Putscher and Caroline Weber of the Delaware Department of Natural Resources and Environmental Control for providing sampling assistance and historical data for the study. The Delaware Geological Survey, especially Kenneth Woodruff, provided historical data and was instrumental in arranging for the drilling of the test holes. David Drummond of the Maryland Geological Survey provided assistance with the model simulations. Laboratory analysis of core samples and geologic data were supplied by Bruce Uibel of the Army Corps of Engineers. Thanks are given to the Artesian Water Company; the city of New Castle Board of Water and Light; ICI Americas, Inc. (ICI); Crown Films, Inc.; Delaware National Guard; Delaware City; and Texaco Oil Refining Company for permission to sample their wells. 


\section{HYDROGEOLOGY}

An understanding of the hydrogeology of the flow system is required in order to analyze the interaction of the Potomac aquifers and the Delaware River. Knowledge is required about these factors: (1) the depth and distribution of the Potomac aquifers, (2) the nature of the sediments overlying the Potomac aquifers under the river, and (3) the direction and magnitude of the hydraulic gradient between the Potomac aquifers and the Delaware River.

This report focuses on the extent and distribution of the uppermost Potomac aquifer and overlying confining unit in the vicinity of the Delaware River. Hydrogeologic sections are used to illustrate the continuity of the uppermost aquifer underlying the river.

Sediments overlying the uppermost Potomac aquifer consist of the Potomac clay and silt (confining unit), sand and gravel of the Columbia Group, undifferentiated (Columbia aquifer), and Holocene sediments ( $t a b l e$ 1). The Potomac clay and silt, where continuous, act as confining units. On land, the Columbia Group sediments act as the unconfined aquifer and is termed the "Columbia aquifer." The Columbia sediments are rather permeable and generally are conduits for water movement between the Potomac aquifers and the river. The Holocene sediments principally underlie the river and act as a confining unit.

The hydraulic gradient between the aquifers and the river is affected by pumpage from the aquifers. In areas where the aquifers are relatively unstressed, potentiometric heads are above the altitude of the river, resulting in ground-water discharge to the river. Conversely, gradients are from the river to the aquifers in areas where pumping has lowered potentiometric heads below the river level.

\section{Aquifers and Confining Units}

Potomac Aquifers

\section{Lithology}

The lithology of the Potomac Formation has been described by McGee (1886), Jordan (1962, p. 6), Sundstrom and others (1967, p. 17), Martin and Denver (1982, p. 10), and Jordan (1983, p. 18-20). Jordan (1962, p. 6) stated that the Potomac Formation consists of white, gray, and rust-brown quartz sand with some gravel; variegated white, yellow, and red silt and clay; and some beds of gray clay containing finely disseminated carbonaceous matter and lignite.

The sand in the Potomac Formation is primarily quartzose (Jordan, 1962, p. 6) with variable amounts of feldspar, although not enough to warrant the term arkosic (Groot, 1955, p. 27). Jordan (1983, p. 15) noted that thin layers of limonite cementation of sand and gravelly sand is common throughout the Potomac Formation. Jordan also stated that the depositional environment was an alluvial plain spreading by multiple fans along the 
margin of the Appalachian Highlands. Groot (1955, p. 103) surmised that the paleoenvironment was a low-lying, swampy Coastal Plain in which fluviatile, bimodal sediments were deposited--some in brackish, swampy lagoons and estuaries and some in stream channels and flood plains.

The resulting sediment distribution is dominated by small-scale, fining-upward sequences, characterized by irregular sand bodies in a silty clay matrix. Sand was separated from the clay and silt fractions by stream action and was deposited mainly in stream channels (Sundstrom and others, 1967, p. 18). The sand bodies, because they were generally confined to the channels of the depositing streams, are elongate and tabular rather than sheetlike (Sundstrom and others, 1967, p. 18).

\section{Extent}

The vertical and horizontal variability of sediment distribution in the Potomac Formation makes aquifer correlation difficult. Previous workers have divided the Potomac Formation into a hydrologic system with two or three aquifers. The Potomac Formation was divided into upper and lower aquifers by Sundstrom and others (1967, p. 21). Woodruff (1985) stated that most of the Potomac Formation is characterized by two aquifers, although some areas in New Castle County show evidence for three aquifers. Rasmussen and others (1957, p. 111-115) designated the lower, middle, and upper Potomac aquifers within the Potomac Formation. Martin (1984) used the three-aquifer breakdown for a digital flow model of the Potomac Formation in New Castle County. The three-aquifer breakdown is also used in this report.

The extent of the uppermost of the three Potomac aquifers in the vicinity of the Delaware River was determined from drillers' logs and geophysical logs. Figure 2 shows the location of the data points and hydrogeologic sections used to determine aquifer extent. The data reveal that the upper Potomac aquifer is the uppermost aquifer in the area between Red Lion Creek and the town of New Castle. North of New Castle to the Delaware Memorial Bridge (Memorial Bridge), the middle Potomac aquifer is the uppermost aquifer underlying the Delaware River. North of the Memorial Bridge to the Fall Line, the middle Potomac aquifer pinches out and the lower Potomac aquifer becomes the uppermost aquifer.

The depth and vertical extent of the upper Potomac aquifer and related units is shown in the hydrogeologic sections, figures 3 through 6 . Section A-A', shown in figure 3, extends from north of Red Lion Creek east into New Jersey (fig. 2). Figure 3 shows that the top of the upper Potomac aquifer in the area north of Red Lion Creek is 88 to $112 \mathrm{ft}$ below sea level, with a thickness of approximately $20 \mathrm{ft}$. The aquifer is not continuous beneath the river, as shown by data from boreholes Dc44-4 through Dc45-5; however, the hydraulic connection is provided by the Columbia sand and gravel beneath the river. The upper Potomac aquifer is present in borehole Dd41-2 at $64 \mathrm{ft}$ below sea level and extends eastward towards New Jersey. 


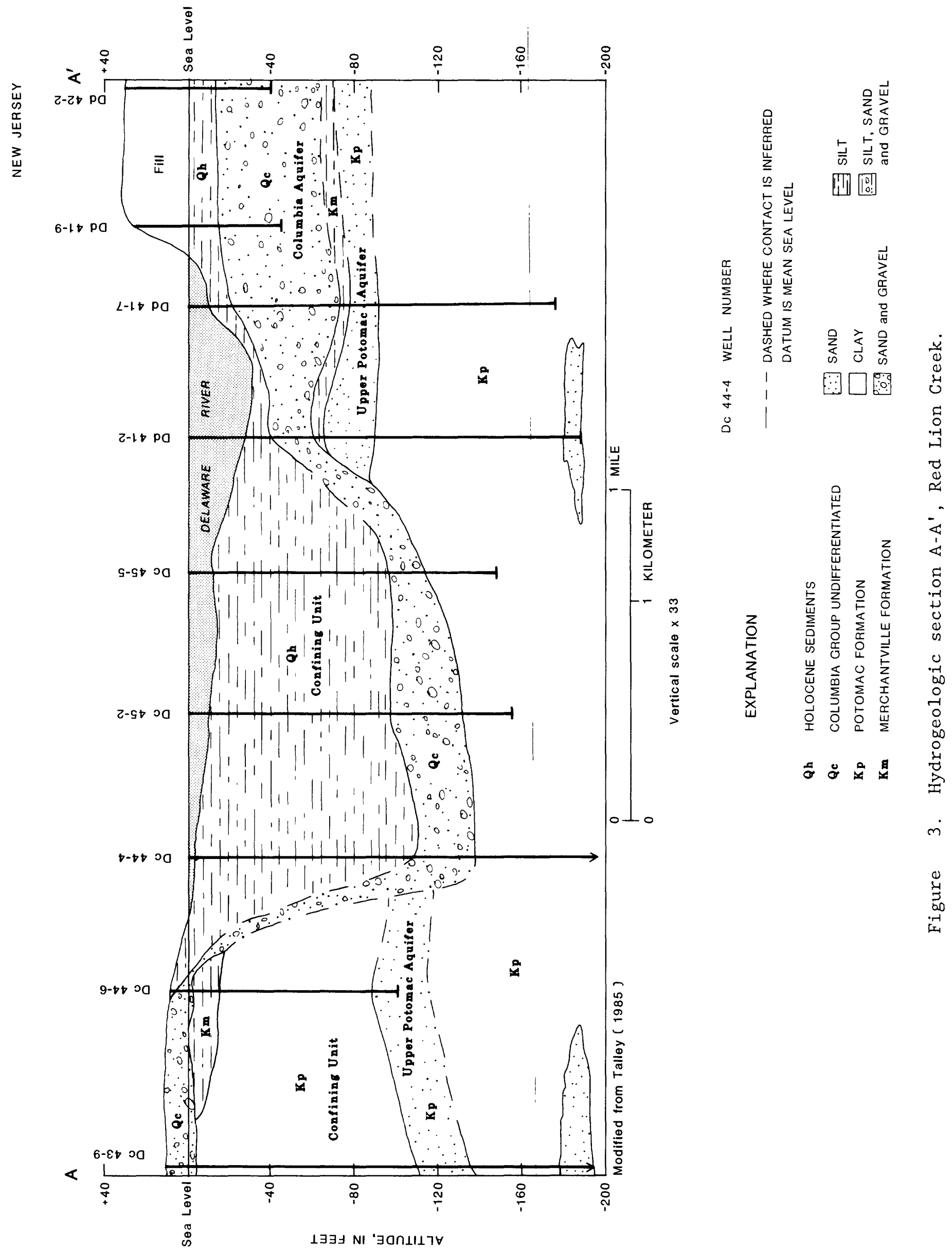


The upper Potomac aquifer underlying Artisans Village and Crown Films consists of two sand units separated by a of clay bed of limited extent (fig. 4). The top of the upper and lower sand units is from 32 to $72 \mathrm{ft}$ and 92 to $120 \mathrm{ft}$ below sea leve1, respectively. The upper sand is relatively thin, ranging in thickness from 5 to $40 \mathrm{ft}$, whereas the lower sand is at least $80 \mathrm{ft}$ thick. The intervening clay bed contains some sand lenses, but is fairly continuous, except beneath Llangollen Estates (boring Dc24-19) where the thickness is only a few feet.

Figure 5 depicts a section underlying the Delaware River, south of New Castle, near Crown Films ${ }^{1}$. The two sand units of the upper Potomac aquifer underlie the Amoco and Crown Films well fields (boreholes Dc25-16 and Dc2527). The upper sand is missing in some areas underlying the Delaware River (boreholes Dd21-1 and Dd32-2). East of Crown Films, the continuity and thickness of the underlying clay and lower sand unit is difficult to determine because of a lack of depth control.

The upper Potomac aquifer is present west of New Castle, but becomes thin and discontinuous in the vicinity of the Delaware River (fig. 6). The thickness of the upper Potomac aquifer ranges from 18 to $42 \mathrm{ft}$ beneath the western part of the New Castle well field, but is only $10 \mathrm{ft}$ thick under the eastern part (borehole Cd52-27). The upper Potomac aquifer is missing entirely offshore at New Castle (borehole Dd12-4).

The middle Potomac aquifer is the most important aquifer in the area between eastern New Castle and the Memorial Bridge. Figure 6 shows the middle Potomac aquifer underlying the eastern New Castle well field (borehole Cd52-27) at approximately $100 \mathrm{ft}$ below sea 1 evel and $120 \mathrm{ft}$ under the Delaware River (borehole Dd12-4). Figure 7 reveals the middle Potomac aquifer at about $120 \mathrm{ft}$ below sea level east of New Castle, but continuity of the unit under the river towards the Memorial Bridge cannot be determined due to lack of data.

The middle Potomac aquifer underlies the river at the Memorial Bridge at a depth of 100 to $152 \mathrm{ft}$ below sea level (fig. 8). Figure 8 indicates that the aquifer is continuous to the west, underlying the ICI and Collins Park well fields at a depth of 48 to $60 \mathrm{ft}$ below sea level, with a thickness of about 20 to $30 \mathrm{ft}$. There is some question as to whether the sand unit underlying the ICI we11 field between 60 and $76 \mathrm{ft}$ below sea level is the Potomac Formation or Columbia Group. A heavy-mineral analysis performed on a core taken at $70 \mathrm{ft}$ below sea level from boring Cd43-16 indicated the sand belonged to the Columbia Group (K. D. Woodruff, Delaware Geological Survey, oral commun., 1986). The sand unit underlying the Collins Park well field at 48 to $60 \mathrm{ft}$ below sea level is the Potomac Formation. The driller's logs from boreholes Cd42-17 and Cd43-1 describe the overlying clay as a red and

1 The use of industry or firm names in this report is for location purposes only, and does not impute responsibility for any present or potential effects on the natural resources. 


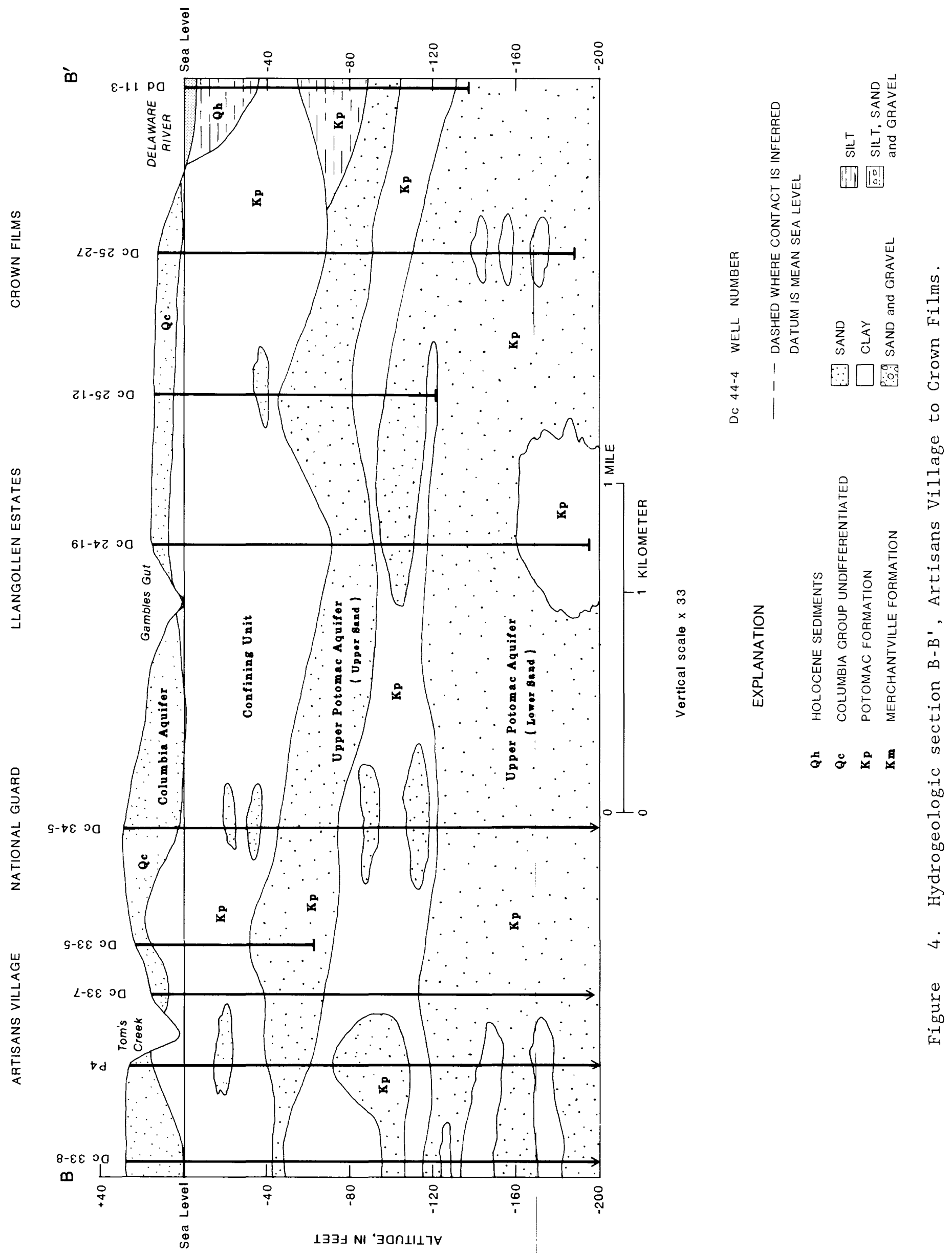




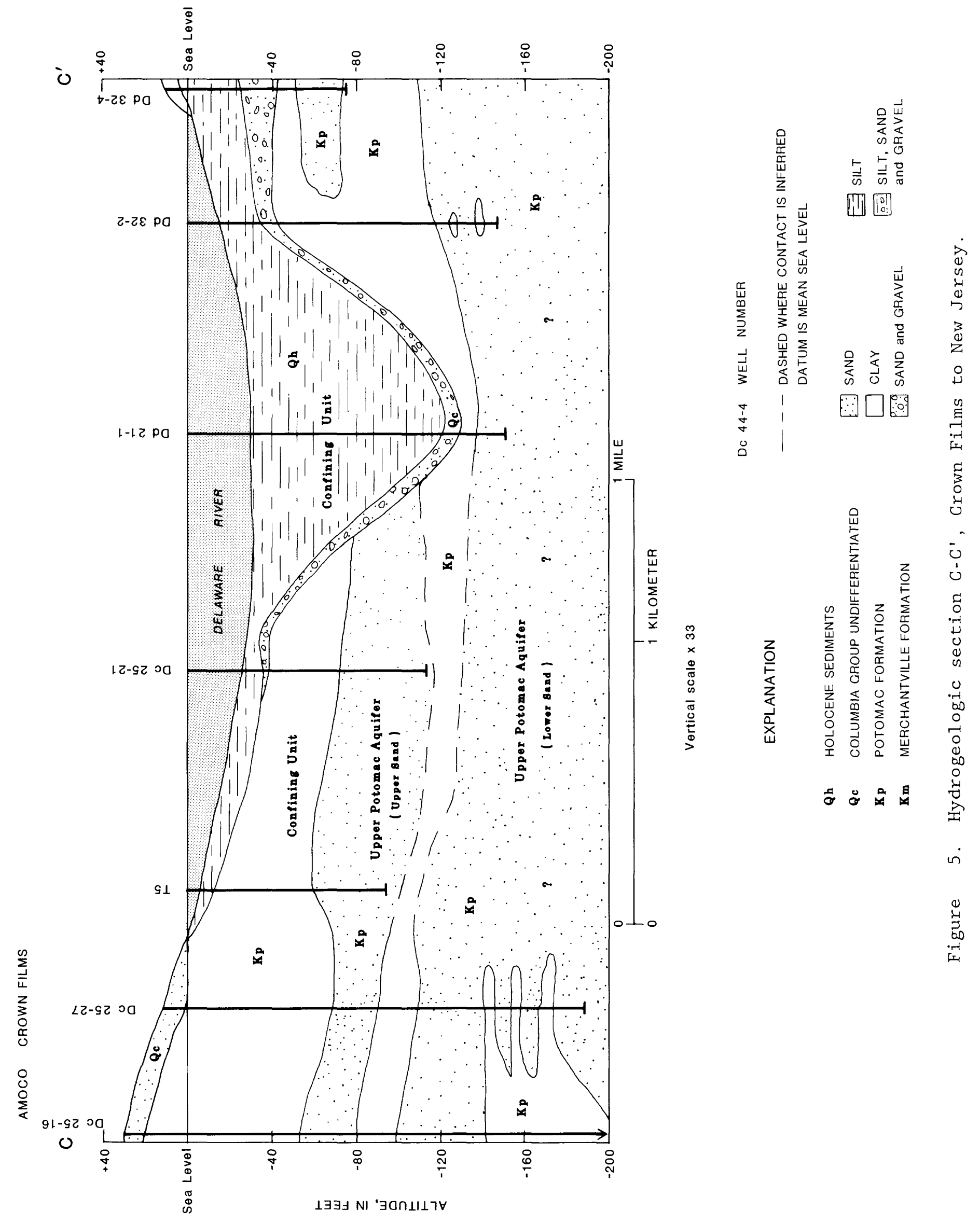




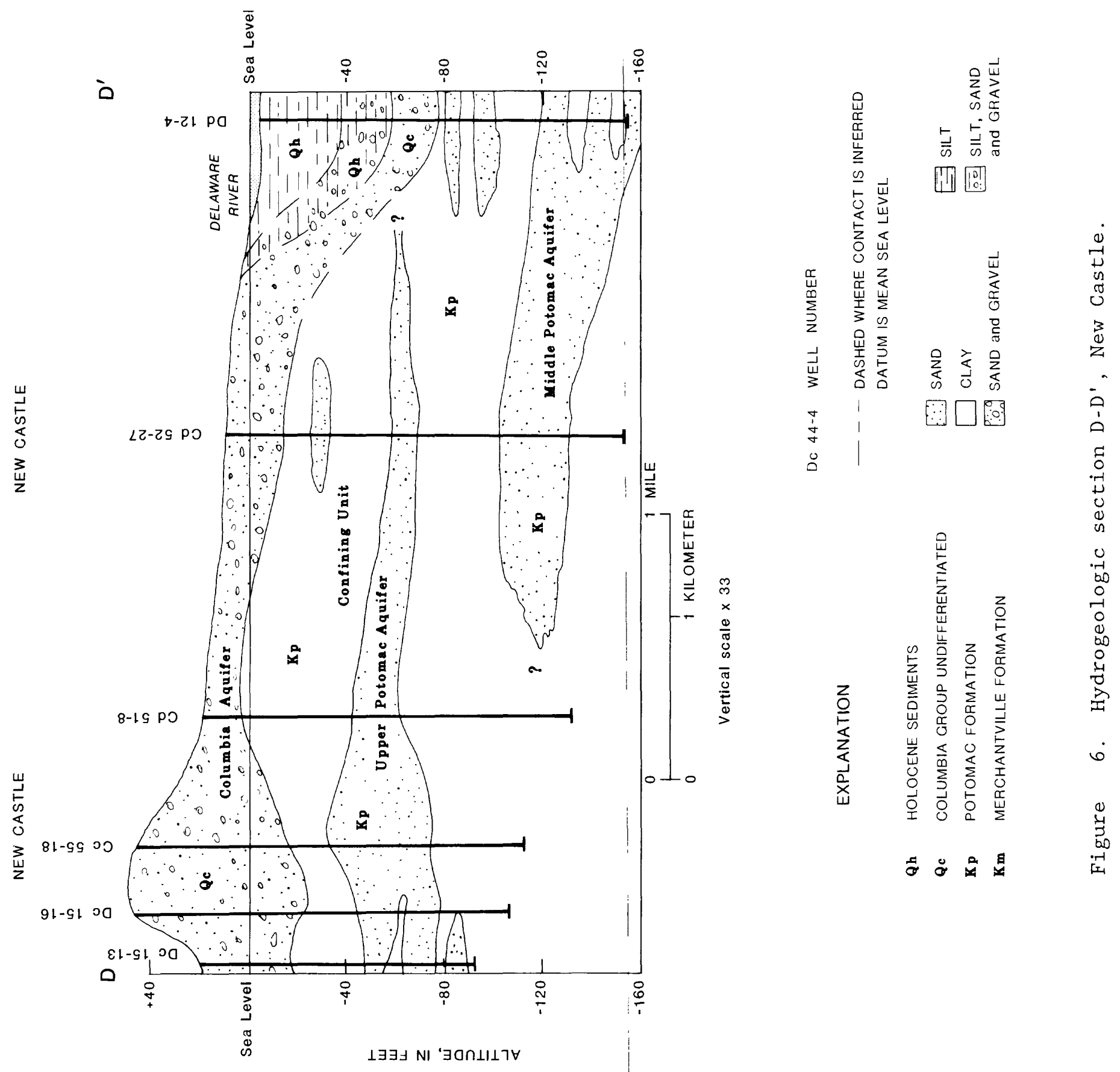




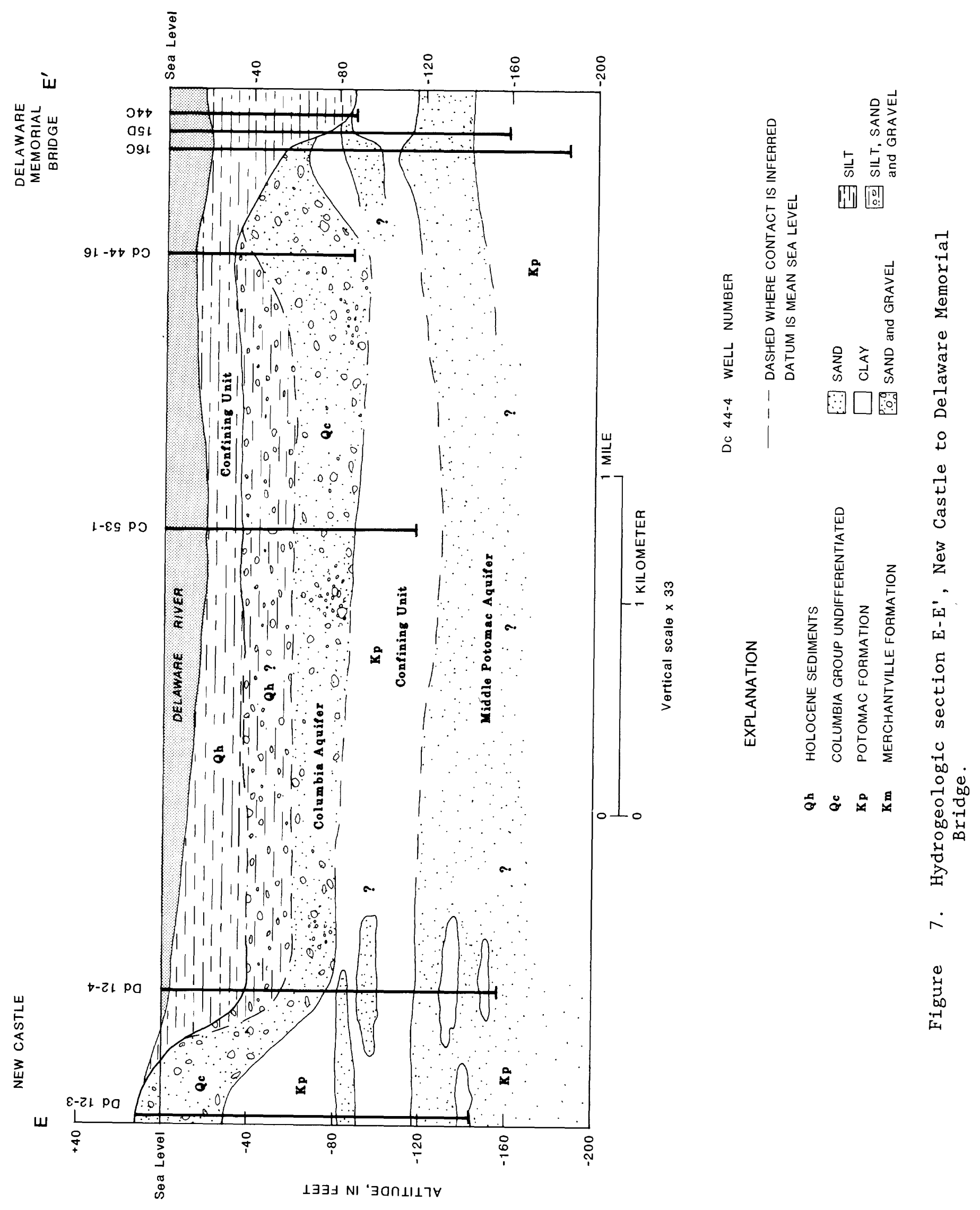




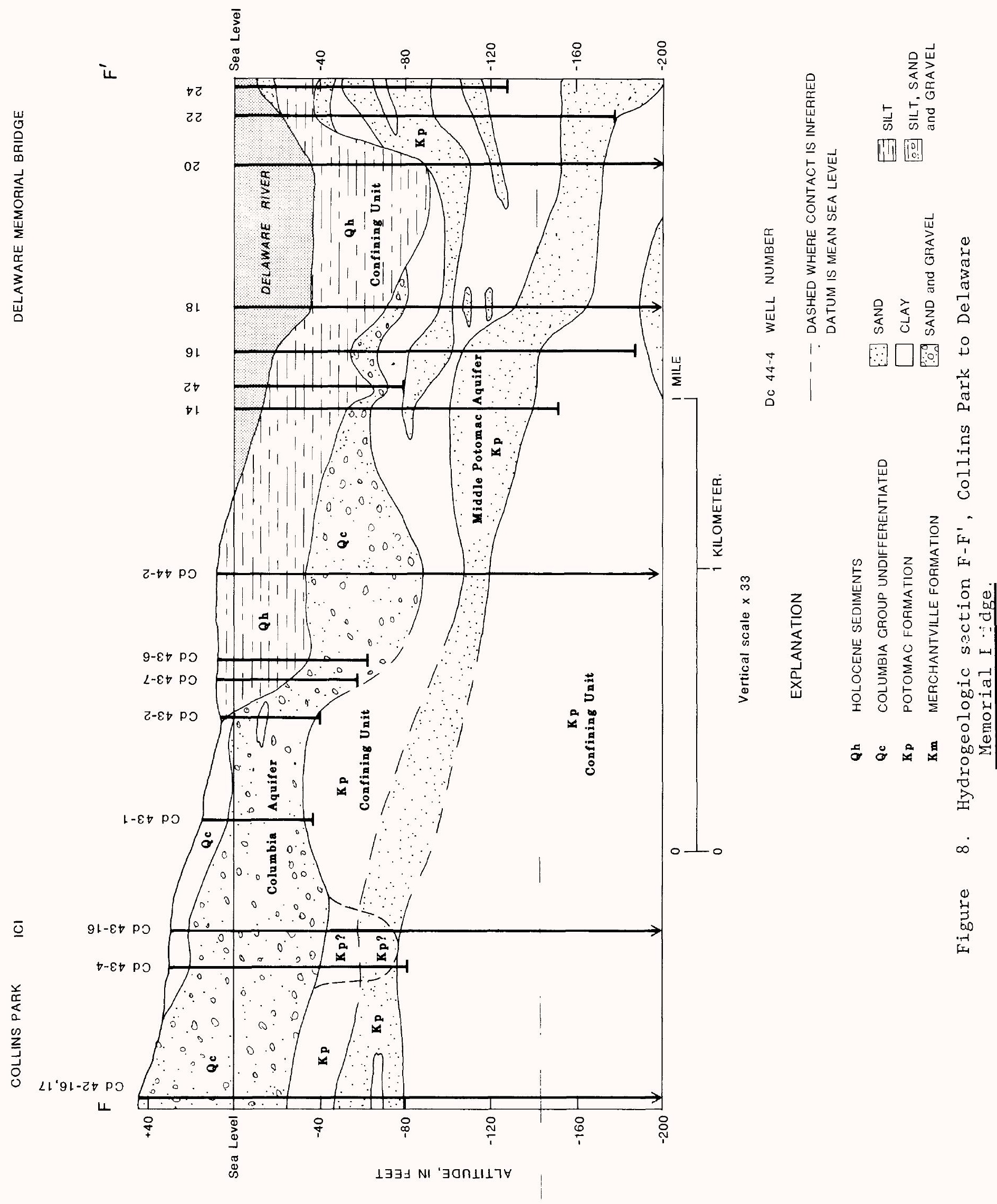


white to varigated clay, which is indicative of a Potomac clay. The clay in boreholes Cd43-4 and Cd43-16 is a "blue" clay and cannot be positively identified as a Potomac clay, but the clay is fairly continuous in the Collins Park-ICI area. Although the sand unit 60 to $76 \mathrm{ft}$ below sea level beneath the ICI well field could be a paleochannel in the Columbia Group, it functions as part of the middle Potomac aquifer because of the overlying confining clay and hydraulic continuity with the Potomac sand at the Collins Park well field.

Delineation of the Potomac aquifers north of the Memorial Bridge is difficult because of a lack of deep boreholes. Duran (1985) used marine seismic-reflection and electromagnetic-conductivity techniques to characterize channel bottom sediments of the Delaware River north of the Memorial Bridge. Analysis of the data suggests that the Potomac aquifers are not present at a depth of $100 \mathrm{ft}$ below sea level under the river channel from the Memorial Bridge to near Cherry Island. North of Memorial Bridge, the Potomac Formation is mostly fine grained, containing relatively thin and discontinuous sand bodies. In general, the Potomac Formation lacks productive aquifers in the vicinity of Pigeon Point and Cherry Island.

\section{Hydraulic properties}

The sediment variability of the Potomac Formation is reflected in the wide range of values for aquifer properties. The range in values is primarily a function of the lithology, thickness, lateral extent, and degree of interconnection of sand bodies within a localized area.

Martin and Denver (1982, table 1) reported transmissivity values of 454 to $8,480 \mathrm{ft}^{2} / \mathrm{d}$ (feet squared per day) from analysis of aquifer tests of the Potomac aquifers. Transmissivity values used to calibrate a groundwater flow model of the Potomac aquifers (Martin, 1984) were lowest in the lower aquifer and highest in the upper aquifer. The maximum transmissivity values used in the model for the lower, middle, and upper aquifer were $1,500,3,500$, and $6,000 \mathrm{ft}^{2} / \mathrm{d}$, respectively.

Storage coefficients in the Potomac aquifers range from $5.6 \times 10^{-5}$ to $3.8 \times 10^{-3}$ (Martin and Denver, 1982, p. 15). The average value, $5.6 \times 10^{-4}$, was used by Martin (1984) for the flow model of the Potomac aquifers.

\section{Upper Potomac Confining Unit}

The fine-grained Potomac sediment functions as a confining unit for the uppermost Potomac aquifer in the study area. Similar to the aquifer descriptions, this report describes only the uppermost Potomac confining unit, whether it overlies the lower, middle, or upper Potomac aquifer. Confining units control the amount of leakage from recharge areas and the vertical leakage between aquifers. The fine-grained Potomac sediment underlying the Delaware River acts as a barrier to the infiltration of river water. 


\section{Lithology}

Jordan (1962, p.6) stated that the fine-grained sediment in the Potomac Formation consisted of variegated white, yellow, and red silt and clay, and some beds of gray clay containing finely disseminated carbonaceous matter and lignite. Groot (1955, p. 103) noted the association of pyrite and marcasite with the lignite fragments. Talley (1985) performed grain-size analysis of the fine-grained Potomac sediment underlying the Delaware River. The texture of the sediment ranged from a sandy clay to clayey silt.

\section{Extent}

The extent and distribution of the Potomac confining unit underlying the Delaware River is quite variable. The distribution of the confining unit overlying the upper Potomac aquifer is best illustrated in figures 3 through 5. North of Red Lion Creek, the altitude of the top of the Potomac confining unit is approximately at sea level and is about a $100 \mathrm{ft}$ thick (fig. 3). However, just offshore, the confining unit and upper Potomac aquifer have been removed, as evidenced in boreholes Dc44-4, Dc45-2, and Dc45-5. The confining unit underlying the Delaware shore is continuous from Artisans Village to near Crown Films (fig. 4). Confining-unit thickness ranges from about $50 \mathrm{ft}$ near Artisans Village to about $90 \mathrm{ft}$ at Llangollen Estates (borehole Dc24-19). Thickness varies from 60 to $70 \mathrm{ft}$ underlying the Crown Films well field (borehole Dc25-27). Figure 5 reveals the confining unit has been removed (Dd21-1) underlying the river adjacent to the Crown Films and Amoco well fields.

The Potomac confining unit overlying the middle Potomac aquifer near eastern New Castle (borehole Cd52-27) is about $95 \mathrm{ft}$ thick, but has several interbedded sand bodies (figs. 6 and 7). Offshore from New Castle, the Potomac confining unit has been eroded to almost $80 \mathrm{ft}$ below the Delaware River. The erosional surface appears to be continuous northward to the Memorial Bridge where it reaches a depth of $90 \mathrm{ft}$ below sea level (fig. 7). The thickness of the confining unit in this stretch of the river is difficult to determine. The driller's log from borehole Dd12-4 reveals a thickness of about $40 \mathrm{ft}$, but examination of geophysical logs indicates numerous interbedded sand and sandy-clay lenses. Figures 7 and 8 indicate that confining-unit thickness underlying the Memorial Bridge is quite variable. Boreholes $16 \mathrm{c}$ through $44 \mathrm{c}$ show that the depth of the confining unit varies $20 \mathrm{ft}$ over a very short distance, with thicknesses between 20 to $40 \mathrm{ft}$ (fig. 7). The confining unit under the Memorial Bridge contains interbedded sands (fig. 8). The erosional surface of the Potomac sediments exists under the ICI and Collins Park well fields (fig. 8). Figure 8 indicates the top of the confining unit ranges from 24 to $116 \mathrm{ft}$ below sea level, with a thickness of 8 to $40 \mathrm{ft}$.

In some areas of the shipping channel north of the Memorial Bridge, the top of the Potomac confining unit directly underlies the Delaware River (Duran, 1985). West of the shipping channel, near Pigeon Point and Cherry Island, the top of the confining unit has been eroded to a depth of 80 to $120 \mathrm{ft}$ below sea level. 


\section{Hydraulic properties}

Vertical hydraulic conductivities of the upper Potomac confining unit were obtained from laboratory testing of samples by the COE and from previously ${ }_{6}$ published data; values provided by the COE range from $3.3 \times 10^{-10}$ to $4.9 \times 10^{-6} \mathrm{ft} / \mathrm{s}$ (feet per second) (table 2). Martin and Denver (1982, p. 13) reported vertical hydraulic conductivities of $9.6 \times 10^{-8}$ to $3.7 \times 10^{-5} \mathrm{ft} / \mathrm{s}$, whereas Sundstrom and others (1967, p. 55) listed values of $3.4 \times 10^{-11}$ to $1.0 \times 10^{-9} \mathrm{ft} / \mathrm{s}$.

\section{Columbia Aquifer and Holocene Sediments}

The previous discussion describes the occurrence of extensive erosion of the Potomac sediments. The erosion resulted from a lowering of sea level during Pleistocene time, and the subsequent downcutting of Pleistocene rivers into the underlying Potomac sediments. In northern Delaware, the geologic events during the Pleistocene resulted in erosion of the Potomac Formation and deposition of sand, gravel, and clay of the Columbia Group (undifferentiated). The sediments of the Columbia Group comprise the Columbia aquifer in the study area. The overlying sediment was deposited during Holocene time. The Holocene sediment is primarily silt, silty sand, and some gravel and peat deposits.

\section{Lithology and extent}

Detailed lithology of the Columbia Group was presented by Jordan (1962, p. 35-43). The sediments are predominantly tan, reddish-brown sand and gravel, with some thin beds of silt and clay. The sand is mostly quartz with some feldspar and small amounts of mica and rock fragments. Talley (1985) also reported traces of glauconite.

The Holocene sediments are dark gray, slightly micaceous and organic, relatively uncompacted silts with thin lamellar concentrations of very fine sand (Jordan and Groot, 1962, p. 1). Peat deposits are also associated with the Holocene sediments.

The distribution of the Columbia Group and Holocene sediments reflects the glacial events and related changes in sea level during the Quaternary Period. The factors controlling Quaternary sedimentation in the study area have been described by Jordan (1964, p. 40-41), Jordan and Groot (1962), and Spoljaric (1967, p. 6-11).

The distribution and sedimentary nature of the paleochannels in New Castle County has been described by Rasmussen and others (1957), Jordan (1964), Spoljaric (1967), and Woodruff and Thompson (1975). The mapping completed by previous workers was supplemented with additional data to provide a more detailed delineation of the paleochannels.

Three predominant paleochannels are present within the study area (fig. 9). The first channel, or western channel, begins near Interstate 295 west of the Memorial Bridge and trends southwest through Castle Hills towards 
Table 2.--Vertical hydraulic conductivities and pore-water chloride concentrations for the Potomac and Holocene sediments

[ft $=$ foot; $\mathrm{ft}^{3} / \mathrm{s}=$ cubic feet per second; $\mathrm{mg} / \mathrm{L}=\mathrm{mill}$ igrams per liter - = a dash indicates data not collectedj

\begin{tabular}{|c|c|c|c|c|c|c|c|c|}
\hline $\begin{array}{l}\text { Well } \\
\text { No. }\end{array}$ & $\begin{array}{l}\text { Sample } \\
\text { No. }\end{array}$ & Description & $\underset{\text { unit }}{\text { Geologic }}$ & & $\begin{array}{l}\text { Sample } \\
\text { depth } \\
(\mathrm{ft})\end{array}$ & $\frac{\text { Hydraulic conduc }}{\text { Estimate }}$ & $\frac{\text { tivity }(\mathrm{ft} / \mathrm{s})^{2 /}}{\text { Laboratory }}$ & $\begin{array}{l}\text { Pore-water } \\
\text { chloride } \\
\text { concentrations } 3 \\
\text { (mg/L) }\end{array}$ \\
\hline Dd11-3 & 538 & $\begin{array}{l}\text { Gray inorganic silty } \\
\text { clay with some sand }\end{array}$ & Holocene & 37.0 & to 38.5 & $0.33-3.3 \times 10^{-7}$ & - & 448 \\
\hline Dd11-3 & 540 & Gray silty sand & Holocene & 57.0 & to 58.5 & $\cdot$ & - & 152 \\
\hline Dd11-3 & & Red and white clay & Potomac & 117.0 & to 1118.5 & - & - & $\underline{4} / 116$ \\
\hline Dd12-4 & $544 A$ & $\begin{array}{l}\text { Gray clay with a little } \\
\text { sand, slightly organic }\end{array}$ & Holocene & 6.0 & 6.5 & - & $1.3 \times 10^{-7}$ & 1,273 \\
\hline Dd12-4 & $544 \mathrm{~B}$ & do. & Holocene & 6.5 & 7.0 & - & - & 834 \\
\hline Dd12-4 & $544 \mathrm{C}$ & do. & Holocene & 7.0 & 7.5 & - & - & 736 \\
\hline Dd12-4 & 5440 & do. & Holocene & 7.5 & 8.0 & - & $2.3 \times 10^{-8}$ & 643 \\
\hline Dd12-4 & 539 & $\begin{array}{l}\text { Gray inorganic silt, with } \\
\text { a trace of sand, clayey }\end{array}$ & Holocene & 37.0 & 38.5 & $.33-3.5 \times 10^{-8}$ & - & - \\
\hline Dd12-4 & 542 & Gray silty sand & Potomac & 97.0 & 98.5 & $.49 \cdot 4.9 \times 10^{-6}$ & - & 894 \\
\hline $\operatorname{cd} 53-1$ & $545 A$ & $\begin{array}{l}\text { Gray clay, slightly } \\
\text { organic }\end{array}$ & Holocene & 36.0 & to 36.5 & - & $6.6 \times 10^{-9}$ & 542 \\
\hline $\operatorname{cd} 53-1$ & $545 B$ & do. & Holocene & 36.5 & 37.0 & $\cdot$ & - & 219 \\
\hline Cd53-1 & $545 \mathrm{C}$ & do. & Holocene & 37.0 & to 37.5 & . & - & 210 \\
\hline Cd53-1 & 5450 & do. & Holocene & 37.5 & 38.0 & - & - & 249 \\
\hline Cd53-1 & $545 \mathrm{E}$ & do. & Holocene & 38.0 & to 38.5 & $\cdot$ & $3.6 \times 10^{-8}$ & 183 \\
\hline Cd53-1 & 543 & Gray clayey sand & Holocene & 77.0 & to 78.0 & $.33-3.3 \times 10^{-6}$ & - & 666 \\
\hline WW1 & US1/450 & $\begin{array}{l}\text { Black inorganic silt } \\
\text { with organic material }\end{array}$ & Holocene & -17.0 & to -19.0 & - & $6.8 \times 10^{-8}$ & - \\
\hline WW2 & US $1 / 383$ & $\begin{array}{l}\text { Dark gray soft, clay } \\
\text { with sand lenses }\end{array}$ & Holocene & -26.0 & to -28.0 & - & $3.3 \times 10^{-8}$ & - \\
\hline WW2 & US2/451 & $\begin{array}{l}\text { Dark gray clay with a } \\
\text { trace of sand and } \\
\text { organics }\end{array}$ & Holocene & -36.0 & to -38.0 & - & $9.8 \times 10^{-8}$ & - \\
\hline WW3 & US1/452 & do. & Holocene & -22.0 & to -24.0 & - & $9.8 \times 10^{-8}$ & - \\
\hline WW3 & US2/453 & do. & Holocene & -42.0 & to -44.0 & - & $9.8 \times 10^{-9}$ & - \\
\hline WW4 & US2/454 & do. & Holocene & -32.0 & to -34.0 & - & $3.9 \times 10^{-7}$ & - \\
\hline WW5 & US $1 / 455$ & do. & Holocene & -21.0 & to -23.0 & - & $1.3 \times 10^{-7}$ & - \\
\hline WW5 & US2/385 & $\begin{array}{l}\text { Gray clay with a trace } \\
\text { of fine sand lenses, top } \\
4 \text { inches had a trace of } \\
\text { pea gravel and trace of } \\
\text { organics }\end{array}$ & Holocene & -38.0 & to -40.0 & - & $2.9 \times 10^{-10}$ & - \\
\hline LLB - 2 & US1/388 & $\begin{array}{l}\text { Black clayey inorganic } \\
\text { silt, with a trace of } \\
\text { fine sand }\end{array}$ & Holocene & -23.0 & to -25.0 & $\cdot$ & $5.3 \times 10^{-9}$ & - \\
\hline LLB - 2 & US2/389 & do. & Holocene & -53.0 & to -55.0 & $\cdot$ & $5.6 \times 10^{-9}$ & - \\
\hline
\end{tabular}

1/ Datum is sea Level.

$2 /$ Provided by the U.S. Army Corps of Engineers.

3/ Provided by the U.S. Army Corps of Engineers, except where noted.

4/ Analysis by Lancaster Laboratories. 
Route 13. The second channel, or middle channel, underlies the western shore of the Delaware River from Cherry Island to New Castle. The third channel--the eastern channel--underlies the eastern and central part of the Delaware River.

The western channel is approximately $40 \mathrm{ft}$ below sea level near Interstate 295, shallowing to $20 \mathrm{ft}$ below sea level near Route 13 (fig. 9). This is the shallowest of the three channels. The sediment is about $70 \mathrm{ft}$ thick in the channel axis, but thins away from the axis (figs. 6 and 8). Channel sediments are primarily sand and gravel with a slight fining-upward sequence.

The middle paleochannel underlies the western shore of the Delaware River. The channel comes inland near Cherry Island, continues south underneath the Christina River, and then swings back towards the Delaware River, running adjacent to the Pigeon Point and ICI areas (fig. 9). Near ICI, the western and middle channels are in close proximity, resulting in an interconnection of sand and gravel (fig. 8). South of ICI, the channels diverge. The middle channel underlies the western shoreline and pinches out near New Castle. The depth of the channel axis ranges from 80 to $105 \mathrm{ft}$ below sea leve1; sediment thickness is from 60 to $100 \mathrm{ft}$.

The lithology of the middle channel exhibits a distinct fining-upward sequence and is characteristic of a channel-fill sequence in a braided stream, as described by Reineck and Singh (1975, p. 242). The base of the channel contains gravel and coarse sand (Columbia Group). Overlying these sediments are medium sand, with some gravel and silt, which grades into fine sand and silt (Columbia Group). The top of the sequence contains silt and some organic matter (Holocene sediments). The coarse-grained sequence is 60 ft thick in the channel axis underlying Cherry Island, but thins rapidly and grades into silt away from the axis. Silt thickness overlying the channel axis near Cherry Island is from 40 to $60 \mathrm{ft}$, but increases to 10 to $40 \mathrm{ft}$ away from the Memorial Bridge channel axis (fig. 10). South of Cherry Island to about the Memorial Bridge, the coarse-grained sequence is only 5 to $20 \mathrm{ft}$ thick. Conversely, the overlying silt thickness varies from 40 to $100 \mathrm{ft}$ along this stretch (fig. 10). There is an abrupt facies change from silt to sand and gravel under the Memorial Bridge (fig. 7). Between the Memorial Bridge and New Castle, the thickness of the coarser sediments is between 40 to $60 \mathrm{ft}$. The silt in this channel is almost $60 \mathrm{ft}$ thick under the Memorial Bridge, but thins rapidly towards the shore and pinches out landward (fig. 10).

The eastern channel has a well-preserved channel pattern which underlies the Delaware River and some of the New Jersey shoreline (fig. 9). The thalweg of the channel shifts from the New Jersey shoreline near the Memorial Bridge to the Delaware shoreline adjacent to Red Lion Creek (fig. 9). The channel axis is 80 to $140 \mathrm{ft}$ below sea level, and it is the deepest of the three channels. Figures 3, 5, and 8 illustrate that the sediments of the channel are predominantly fine grained. The thickness of coarse-grained deposits in the base of the channel ranges from 5 to $30 \mathrm{ft}$ under the river, but increases towards the New Jersey shoreline. Silt thickness ranges from 60 to $100 \mathrm{ft}$ in the main channel, but thins rapidly towards the shoreline (fig. 10). 


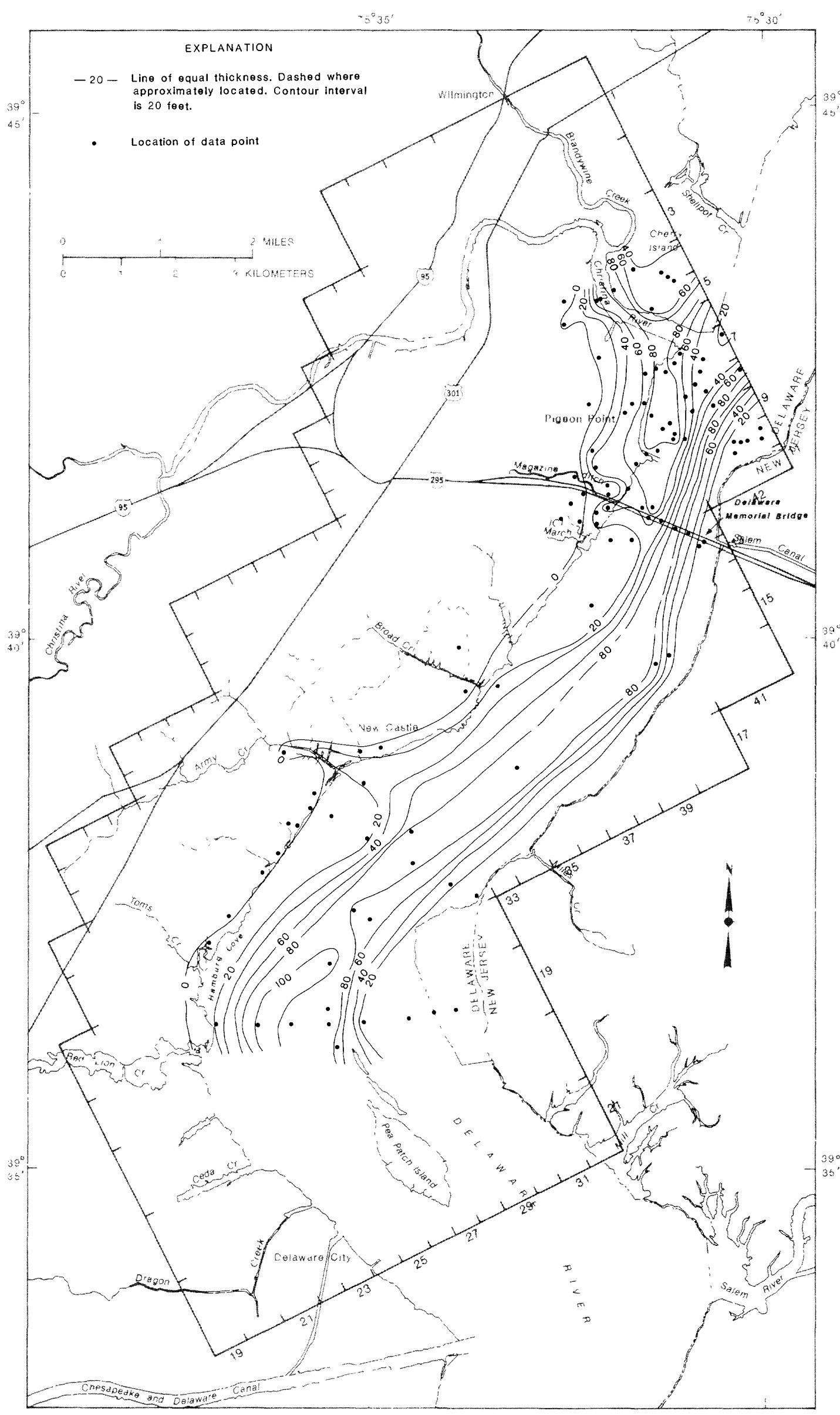

Figure 10. Thickness of the Holocene silt. 
Knowledge of the vertical hydraulic conductivity of the Columbia Group and Holocene sediments is critical in assessing the leakage of river water through the paleochannels underlying the Delaware River. The sand and gravel of the Columbia Group occupies the base of the paleochannels. Moody (U.S. Geological Survey, written commun., 1986) reported values of vertical hydraulic conductivity for the Columbia sediments ranged from $1.7 \times 10^{-6} \mathrm{ft} / \mathrm{s}$ for silty sand to $3.8 \times 10^{-4} \mathrm{ft} / \mathrm{s}$ for sand. The COE reported values of $3.3 \times 10^{-5} \mathrm{ft} / \mathrm{s}$ for silty sand and $3.3 \times 10^{-2}$ for gravel beds (Bruce Uibel,
written commun., 1985).

Vertical hydraulic conductivities of the Holocene sediments are listed in table 2. The values range from $2.9 \times 10^{-10}$ to $3.3 \times 10^{-5} \mathrm{ft} / \mathrm{s}$. Moody (U.S. Geological Survey, written commun., 1986) reported values of $2.2 \times 10^{-7}$ to $4.7 \times 10^{-7} \mathrm{ft} / \mathrm{s}$.

\section{Hydrologic Significance of Pleistocence Erosion}

The previous section discussed the lithology and extent of the Pleistocene paleochannels in northern Delaware. The downward erosion of river channels during Pleistocene time resulted in removal of underlying Cretaceous sediments. The channel-fill sediments deposited after the erosional episodes consisted of sand and gravel of the Columbia Group and Holocene sediments. These sediments have a greater permeability than the Potomac confining unit that had overlain the Potomac aquifers. Therefore, the paleochannels will influence ground-water and surface-water interaction and may act as conduits for the infiltration of river water into the Potomac aquifers.

Chapelle (1985, p. 21) noted that recharge and discharge from the Potomac aquifers near Baltimore, Md., are strongly influenced by Pleistocene erosional channels. The Pleistocene erosion removed the overlying Potomac confining unit which resulted in deposition of more permeable sediment and provided a conduit for water to leak out of or into the Potomac aquifers.

The general areas where the paleochannels will influence the flow system in the underlying aquifers are presented in figure 11. This figure is a composite of figures 9 and 10 and shows the areal distribution of the base of the Columbia Group where it is below sea level and where the overlying Holocene silt thickness is relatively thin (less than $40 \mathrm{ft}$ ). Figure 11 indicates the areas along the shorelines of the Delaware River that have the potential for infiltration of river water into the Potomac aquifers.

The Columbia Group functions as the water-table aquifer in New Castle County. In some areas, the Columbia aquifer is hydraulically connected with the sand and gravel underlying the Delaware River. The overlying Holocene silt acts as the confining unit in the vicinity of the river. This situation is illustrated in figure $12 a$ and occurs in the areas of the middle paleochannel, which extends from New Castle to Cherry Island, and near the New Jersey shoreline. Where the Columbia aquifer continuously underlies the river, the heads in the Columbia aquifer under the river will influence the hydraulic gradient between the river and the Potomac aquifers. Pumpage in 


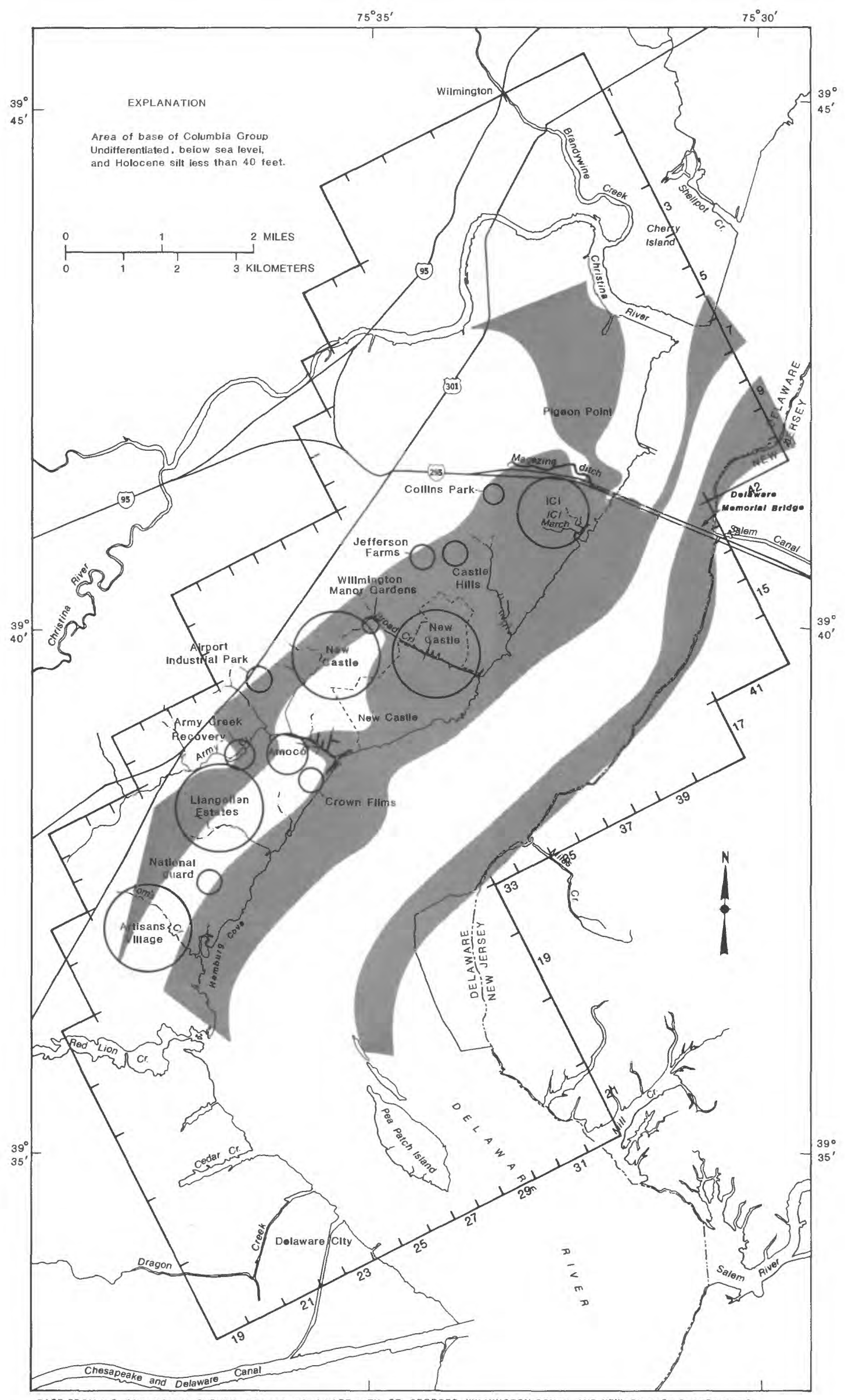

Figure 11. Areal distribution of the base of the Columbia Group, undifferentiated, below sea level, and Holocene silt less than 40 feet thick. 
not to scale

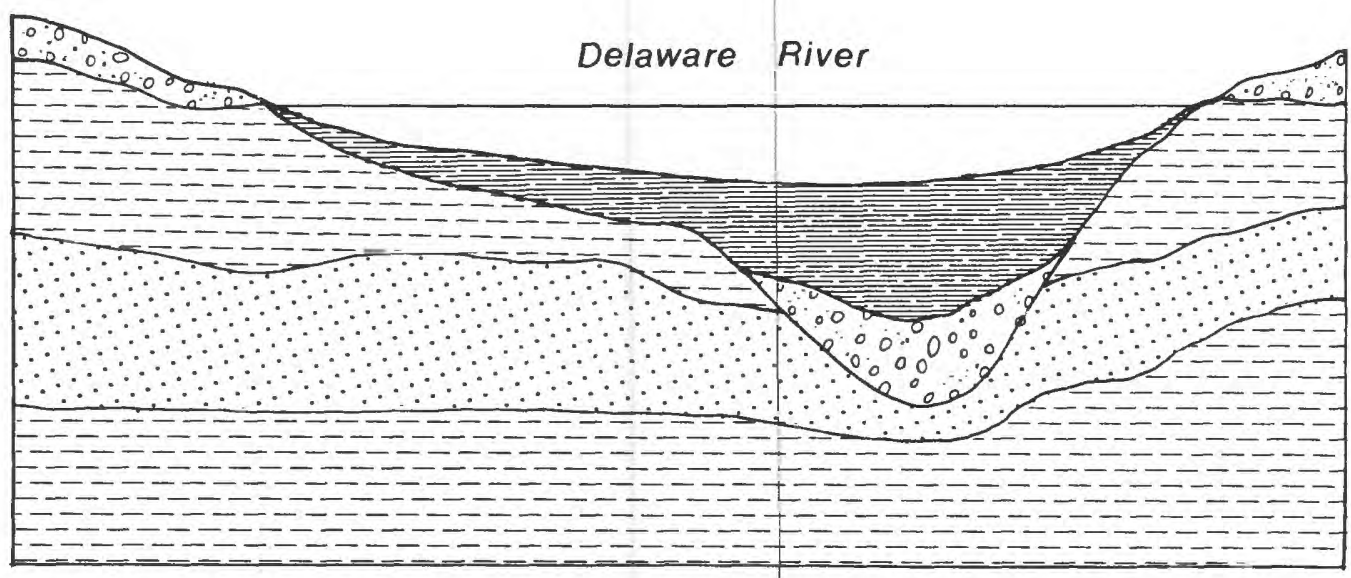

A. Conceptual hydrogeologic framework showing Columbia aquifer discontinuous under river.

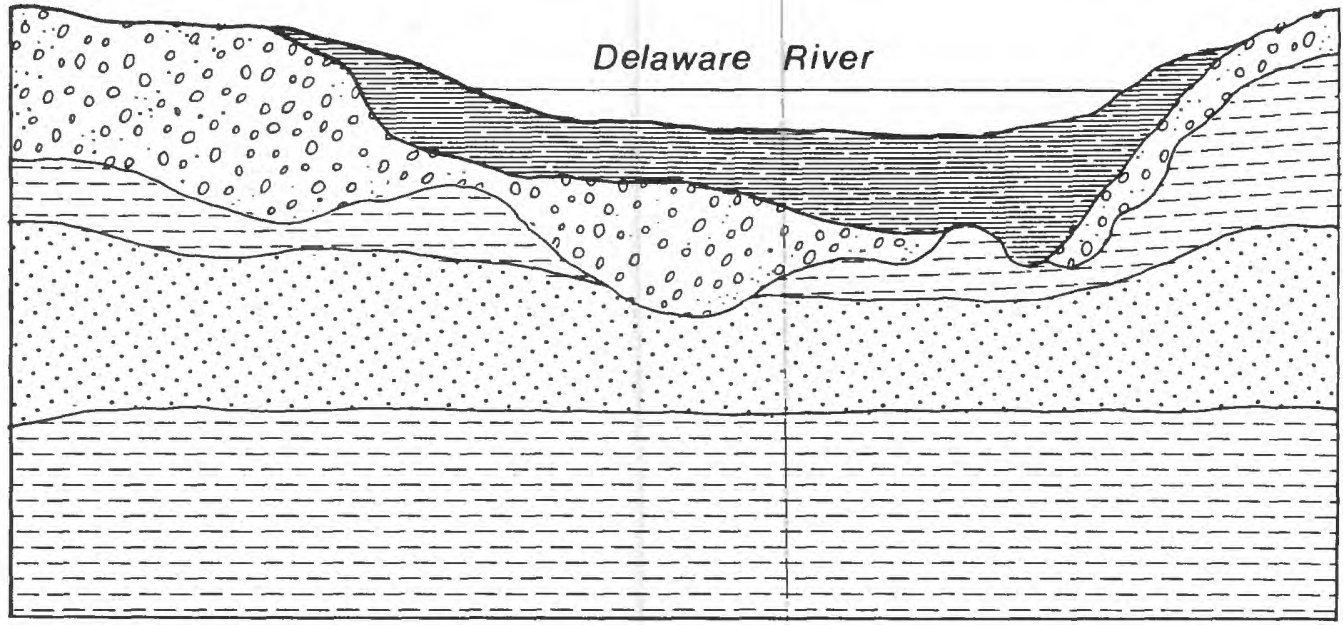

B. Conceptual hydrogeologic framework showing Columbia aquifer continuous under river.

EXPLANATION

㢄量 Holocene silt

[0. Columbia aquifer
E- Potomac clay

$\because$ Potomac aquifer

Figure 12. Generalized hydrogeologic framework of the Columbia aquifer, upper confining unit, Potomac aquifer and underlying confining unit beneath the Delaware River. 
the Columbia aquifer will lower potentiometric heads and result in the infiltration of river water. South of New Castle, the Columbia aquifer is not hydraulically connected with the equivalent sediments deposited in the paleochannels underlying the river. This situation is illustrated in figure 12b. Sediments deposited in the paleochannels exhibit a higher permeability than the Potomac confining unit, thus providing a conduit for the infiltration of river water.

\section{Source and Movement of Ground Water}

The source of ground water for the Potomac aquifers is recharge from the overlying Columbia aquifer. Most of the recharge occurs near the updip extent of the aquifers where sandy zones of the Potomac Formation crop out at, or near, the land surface (Martin, 1984, p.78). During prepumping conditions, much of the water in the Columbia aquifer discharges as base flow into local streams or lakes. The remainder of the ground water flows into the deeper Potomac aquifers.

Martin (1984, fig. 17, p.33) reported that recharge into the Potomac aquifers from the Columbia aquifer was from 0.1 to $2.0 \mathrm{in} / \mathrm{yr}$ (inches per year). Fleck (U.S. Geological Survey, written commum., 1986), using a regional digital simulation of the Coastal Plain sediments in Maryland and Delaware, estimated that recharge to the confined Potomac aquifers in northern Delaware averaged about 2 in/yr. Water in the Potomac aquifers not affected by pumpage flows southeast and eventually discharges into overlying sediments and the Delaware River.

Pumpage from the Potomac aquifers is now the major source of discharge and has caused development of both regional and local cones of depression (Martin and Denver, 1982, p. 7). Pumping began in the early 1900's, but the amount of water withdrawn was considered insignificant before 1955 (Martin and Denver, 1982, p. 18). Withdrawals have steadily increased since 1955 to the current amount of $20 \mathrm{Mgal} / \mathrm{d}$. The resulting decline in aquifer water levels has caused several cones of depression in the upper and middle Potomac aquifers (figs. 13 and 14).

Major pumpage in the upper Potomac aquifer is located at the Artisans Village, Llangollen Estates, Crown Films, Army Creek, Airport Industrial Park, Wilmington Manor Gardens, and New Castle well fields. Figure 13 illustrates that heads at these well fields are between about 20 and $60 \mathrm{ft}$ below sea level. These withdrawals have lowered heads in the upper Potomac aquifer below that of the Delaware River for about a $10-\mathrm{mi}^{2}$ area. The Amoco well field also had large withdrawals from the upper Potomac aquifer during its operation from 1961 to 1981 . Water levels were $30 \mathrm{ft}$ below sea level when the well field was in operation, but have recovered to $20 \mathrm{ft}$ below sea level since abandonment.

Current withdrawals in the middle Potomac aquifer are at the Jefferson Farms, Castle Hills, Collins Park, and ICI well fields (fig. 14). Figure 14 indicates water levels at the well fields are about 20 to $40 \mathrm{ft}$ below sea level and are surrounded by a $5-\mathrm{mi}^{2}$ area in which heads are below that of the Delaware River. The eastern New Castle well field was also a major 


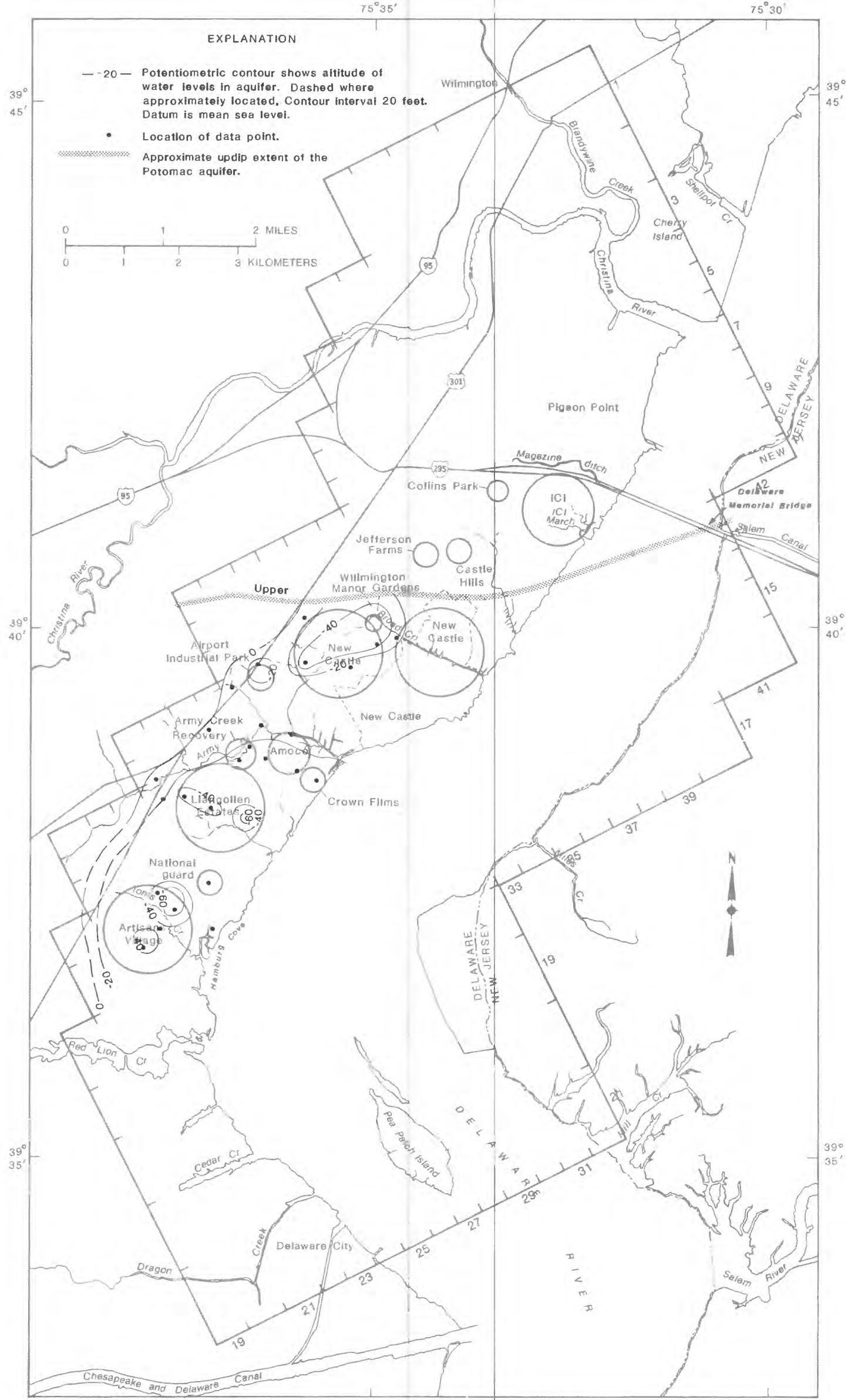

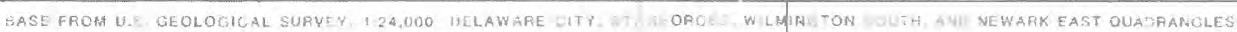

Figure 13. Potentiometric surface of the upper Potomac aquifer during May 1985. 


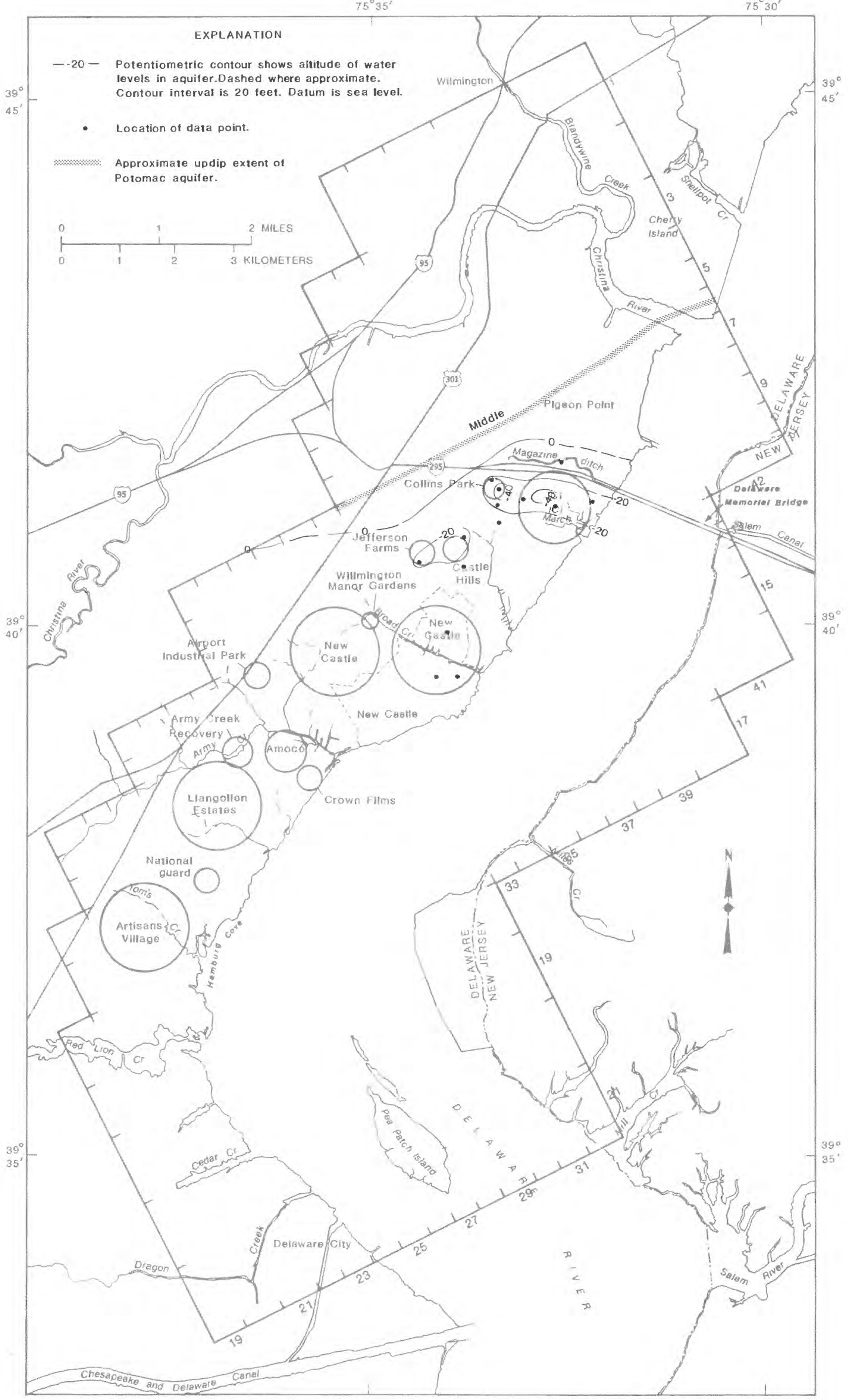

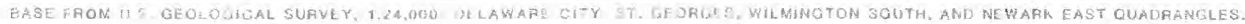

Figure 14. Potentiometric surface of the middle Potomac aquifer during May 1985. 
withdrawal center from the middle Potomac aquifer from 1953 to 1981. Water levels in the production well during operation were $100 \mathrm{ft}$ below sea level (Martin and Denver, 1982, p. 57). Water levels have recovered $95 \mathrm{ft}$ since the we11 was shut down.

The lower Potomac aquifer north of the Memorial Bridge is not productive in the vicinity of the Delaware River. Therefore, a potentiometric surface map was not prepared.

Figures 13 and 14 show that the cones of depression in the upper and middle Potomac aquifers have spread under the Delaware River, locally. In these areas, the hydraulic gradient is from the Delaware River to the Potomac aquifers. A ground-water flow model of the Potomac aquifers (Martin, 1984) simulated this reversal of gradient during a transient calibration of pumping stress from 1956 through 1980. Vertical head differences between the Potomac aquifers and the overlying Delaware River for October 1980 (the end of the simulation) were between 0 to $20 \mathrm{ft}$ for the upper aquifer, 0 to $50 \mathrm{ft}$ for the middle aquifer, and 0 to $120 \mathrm{ft}$ for the lower aquifer (Martin, 1984, p. 81).

\section{Quality of Ground Water and Delaware River}

The ambient water quality of the Potomac aquifers and Delaware River is described to serve as a base for discussions of ground-water degradation. This section discusses the major ion distribution and identification of the chemical controls that influence the water quality in the Potomac aquifers, Columbia aquifer, and Delaware River. Areas of ground-water degradation are discussed in greater detail later in the report.

\section{Ground Water}

The areal distribution of chloride concentrations in the uppermost of the three Potomac aquifers and the Columbia aquifer (Cd44-16 and Cd53-1) during 1984-85 is shown in figure 15. Figure 15 also shows major ion concentrations of selected analyses plotted on Stiff diagrams. The data in this figure include analyses listed in table 3 and sampling results from wells in the vicinity of waste-disposal sites obtained from DNREC. The range of chloride concentrations in the uppermost Potomac aquifers is from 4 to $8,600 \mathrm{mg} / \mathrm{L}$. The wells in the Columbia aquifer, Cd44-16 and Cd53-1, had chloride concentrations of 290 and $400 \mathrm{mg} / \mathrm{L}$, respectively. Stiff plots reveal the major ion composition is quite variable.

The variability of the ground-water quality in the uppermost Potomac aquifer is apparent in figure 15 and is examined on a Durov diagram (fig. 16). Figure 16 shows several analyses plot in the center of the cation and anion fields, which corresponds to a sodium magnesium calcium-chloride sulfate bicarbonate-type water. The corresponding chloride concentrations of these samples range from 10 to $21 \mathrm{mg} / \mathrm{L}$, with specific conductance ranging from 100 to $225 \mu \mathrm{S} / \mathrm{cm}$ (microsiemens per centimeter at $25^{\circ} \mathrm{Celsius}$ ). These analyses represent the ambient water quality in the upgradient areas of the Potomac aquifers. This observation is consistent with previous studies. Back (1966, p. A15) noted that ground water in the undifferentiated Cretaceous sediments near the Fall Line in Virginia exhibited a mixed ionic 


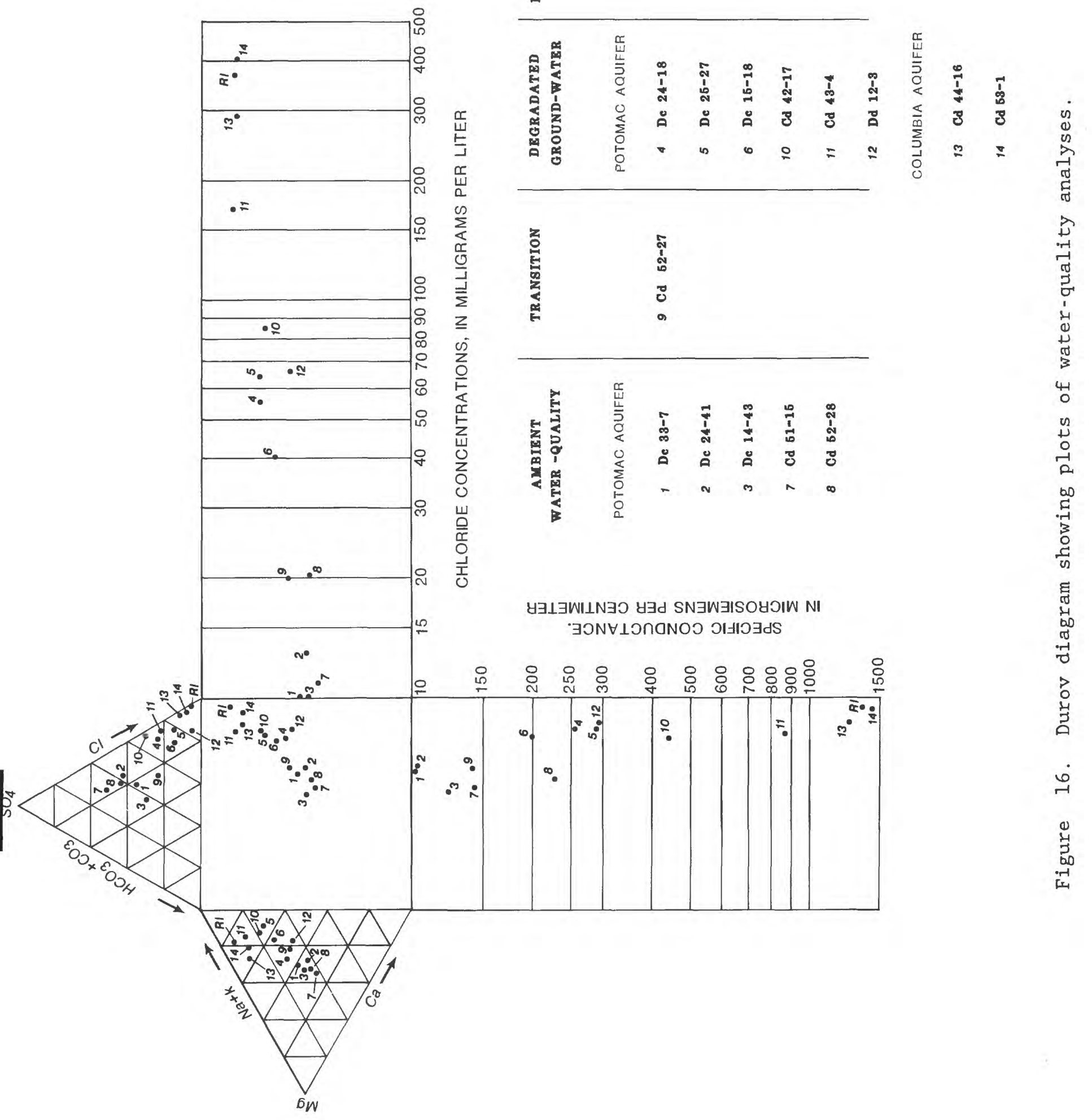


Table 3.--Water-quality analyses for selected wells in New Castle County, Delaware

[ft = foot; $\mathrm{ft}^{3} / \mathrm{s}=$ cubic feet per second; uS $/ \mathrm{cm}=$ microsiemens per centimeter; gal/min = gallons per minute; ug/L = micrograms per liter; $\mathrm{mg} / \mathrm{L}=\mathrm{mill}$ igrams per liter; $=$ a dash indicates data not collectéd]

\begin{tabular}{|c|c|c|c|c|c|c|c|c|c|c|c|c|c|c|}
\hline $\begin{array}{l}\text { Well } \\
\text { No. }\end{array}$ & $\begin{array}{l}\text { Local } \\
\text { Identifer }\end{array}$ & $\begin{array}{l}\text { Station } \\
\text { No. }\end{array}$ & & \multicolumn{2}{|c|}{$\begin{array}{c}\text { Geologic } \\
\text { unit }\end{array}$} & \multicolumn{2}{|c|}{ Date } & \multicolumn{2}{|c|}{$\begin{array}{l}\text { Depth } \\
\text { below } \\
\text { land } \\
\text { surface } \\
\text { (water } \\
\text { level) } \\
\text { (ft) }\end{array}$} & $\begin{array}{l}\text { pth } \\
\text { well } \\
\text { tal } \\
\mathrm{ft} \text { ) }\end{array}$ & \multicolumn{2}{|c|}{$\begin{array}{l}\text { Depth } \\
\text { to } \\
\text { bottom } \\
\text { of sample } \\
\text { sample } \\
\text { interval } \\
(\mathrm{ft})\end{array}$} & $\begin{array}{l}\text { Depth } \\
\text { to top } \\
\text { of } \\
\text { sample } \\
\text { of in- } \\
\text { terval } \\
(\mathrm{ft})\end{array}$ & $\begin{array}{l}\text { Elevation } \\
\text { of land } \\
\text { surface } \\
\text { datum } \\
\text { (ft above } \\
\text { sea } \\
\text { level) }\end{array}$ \\
\hline $\begin{array}{l}\operatorname{cd} 23-14 \\
\operatorname{cd} 23-15 \\
\operatorname{cd} 22-17 \\
\operatorname{cd} 2-17 \\
\operatorname{cd} 43-4\end{array}$ & $\begin{array}{l}010515 \\
031944 \\
040146 \\
040146\end{array}$ & \multicolumn{2}{|c|}{$\begin{array}{l}394304075320901 \\
394328075323001 \\
394133075331101 \\
394133075331101 \\
394125075324901\end{array}$} & \multicolumn{2}{|c|}{$\begin{array}{l}\text { Potomac } \\
\text { Potomac } \\
\text { Potomac } \\
\text { Potomac } \\
\text { Potomac }\end{array}$} & \multicolumn{2}{|c|}{$\begin{array}{l}06-20-84 \\
06-20-84 \\
06-20-84 \\
05-01-85 \\
04-25-85\end{array}$} & $\begin{array}{l}- \\
\cdots \\
\cdots \\
\cdots\end{array}$ & \multicolumn{2}{|c|}{$\begin{array}{r}145.00 \\
53.00 \\
125.00 \\
125.00 \\
104.00\end{array}$} & \multicolumn{2}{|c|}{$\begin{array}{r}110 \\
53 \\
125 \\
125 \\
104\end{array}$} & $\begin{array}{r}95 \\
43 \\
100 \\
100 \\
94\end{array}$ & $\begin{array}{l}10.0 \\
10.0 \\
45.0 \\
45.0 \\
30.0\end{array}$ \\
\hline $\begin{array}{l}\operatorname{cod} 43-3 \\
\operatorname{cod} 4-16 \\
\operatorname{cd} 51-15 \\
\cos 52-27 \\
\cos 52-27\end{array}$ & $\begin{array}{l}010474 \\
62608 \\
10043 \\
033721 \\
033721\end{array}$ & \multicolumn{2}{|c|}{$\begin{array}{l}394132075324801 \\
394130075320001 \\
394050075340001 \\
394058075335001 \\
394058075335001\end{array}$} & \multicolumn{2}{|c|}{$\begin{array}{l}\text { Potomac } \\
\text { Columbia } \\
\text { Potomac } \\
\text { Potomac } \\
\text { Potomac }\end{array}$} & \multicolumn{2}{|c|}{$\begin{array}{l}06-18-84 \\
09-20-85 \\
11-21-85 \\
06-18-84 \\
05-01-85\end{array}$} & $\begin{array}{l}\ddot{3.00} \\
-. \\
13.25\end{array}$ & \multicolumn{2}{|c|}{$\begin{array}{r}103.00 \\
65.00 \\
137.00 \\
141.00 \\
141.00\end{array}$} & \multicolumn{2}{|c|}{$\begin{array}{r}103 \\
65 \\
137 \\
141 \\
141\end{array}$} & $\begin{array}{r}89 \\
55 \\
127 \\
128 \\
128\end{array}$ & $\begin{array}{r}31.0 \\
0 \\
41.4 \\
9.0 \\
9.0\end{array}$ \\
\hline $\begin{array}{l}\text { Cd52-28 } \\
\operatorname{Cd} 53-1 \\
\text { DC14-43 } \\
\text { DC15-18 } \\
\text { Dc24-18 }\end{array}$ & $\begin{array}{l}10047 \\
483941 \\
010050\end{array}$ & \multicolumn{2}{|c|}{$\begin{array}{l}394050075335502 \\
394100075320001 \\
393955075362501 \\
393900075353001 \\
393827075362802\end{array}$} & \multicolumn{2}{|c|}{$\begin{array}{l}\text { Potomac } \\
\text { Columbia } \\
\text { Potomac } \\
\text { Potomac } \\
\text { Potomac }\end{array}$} & \multicolumn{2}{|c|}{$\begin{array}{l}11-21-85 \\
09-24-85 \\
11-21-85 \\
04-30-85 \\
04-30-85\end{array}$} & $\begin{array}{c}6.00 \\
32.50\end{array}$ & \multicolumn{2}{|c|}{$\begin{array}{c}80.00 \\
0.1 \\
118.00 \\
155.00\end{array}$} & \multicolumn{2}{|c|}{$\begin{array}{r}107 \\
80 \\
112 \\
118 \\
155\end{array}$} & $\begin{array}{r}97 \\
70 \\
100 \\
113 \\
115\end{array}$ & $\begin{array}{l}38.0 \\
0 \\
65.0 \\
15.0 \\
19.9\end{array}$ \\
\hline $\begin{array}{l}\text { DC24-41 } \\
\text { DC24-41 } \\
\text { DC25-27 } \\
\text { DC25-27 } \\
\text { Dc33- } 7\end{array}$ & $\begin{array}{l}010050 \\
010050 \\
037604 \\
037604 \\
043962\end{array}$ & \multicolumn{2}{|c|}{$\begin{array}{l}393827075362801 \\
393827075362801 \\
393848075353101 \\
393848075353101 \\
393739075371501\end{array}$} & \multicolumn{2}{|c|}{$\begin{array}{l}\text { Potomac } \\
\text { Potomac } \\
\text { Potomac } \\
\text { Potomac } \\
\text { Potomac }\end{array}$} & \multicolumn{2}{|c|}{$\begin{array}{l}06-19-84 \\
04-30-85 \\
06-21-84 \\
04-25 \cdot 85 \\
06-19-84\end{array}$} & $\begin{array}{l}-- \\
\therefore \\
\cdots \\
-\end{array}$ & \multicolumn{2}{|c|}{$\begin{array}{l}155.00 \\
155.00 \\
183.00 \\
183.00 \\
215.00\end{array}$} & \multicolumn{2}{|c|}{$\begin{array}{l}155 \\
155 \\
183 \\
140 \\
215\end{array}$} & $\begin{array}{l}115 \\
115 \\
129 \\
120 \\
155\end{array}$ & $\begin{array}{l}19.9 \\
47.0 \\
15.0 \\
15.0 \\
15.0\end{array}$ \\
\hline $\begin{array}{l}\text { Dc33- } 7 \\
\text { Dc34- } 7 \\
\text { Ec15-28 } \\
\text { Ec22- } 3 \\
\text { P10A }\end{array}$ & $\begin{array}{l}043962 \\
037981 \\
010053\end{array}$ & \multicolumn{2}{|c|}{$\begin{array}{l}393739075371501 \\
393754075363501 \\
393445075351001 \\
393325075385801 \\
393424075361901\end{array}$} & \multicolumn{2}{|c|}{$\begin{array}{l}\text { Potomac } \\
\text { Potomac } \\
\text { Potomac } \\
\text { Potomac } \\
\text { Potomac }\end{array}$} & \multicolumn{2}{|c|}{$\begin{array}{l}04-23-85 \\
06-19-84 \\
04-30-85 \\
06-21-84 \\
04-24-85\end{array}$} & $\begin{array}{l}-- \\
\therefore \\
\therefore\end{array}$ & \multicolumn{2}{|c|}{$\begin{array}{l}215.00 \\
168.00 \\
737.00 \\
261.00 \\
725.00\end{array}$} & \multicolumn{2}{|c|}{$\begin{array}{l}215 \\
168 \\
737 \\
261 \\
725\end{array}$} & $\begin{array}{l}155 \\
163 \\
707 \\
233 \\
710\end{array}$ & $\begin{array}{l}15.0 \\
17.0 \\
10.0 \\
10.0 \\
10.0\end{array}$ \\
\hline $\begin{array}{c}\text { Well } \\
\text { No. }\end{array}$ & $\begin{array}{l}\text { Sodium, } \\
\text { dissolved } \\
\text { (mg/L } \\
\text { as } \mathrm{Na})\end{array}$ & $\begin{array}{l}\text { Potassium, } \\
\text { dissolved } \\
\text { (mg/L } \\
\text { as K) }\end{array}$ & $\begin{array}{l}\text { Alk } \\
\text { car } \\
\text { IT- } \\
\text { (m } \\
\text { Ca }\end{array}$ & $\begin{array}{l}\text { inity } \\
\text { nate } \\
\text { 3) }\end{array}$ & $\begin{array}{r}\text { Carb } \\
\text { diox } \\
\text { disso } \\
\text { (mg/ } \\
\mathrm{CO}_{2}\end{array}$ & & $\begin{array}{l}\text { sulfate, } \\
\text { dissolved } \\
\text { (mg/L } \\
\left.\text { as } \mathrm{SO}_{4}\right)\end{array}$ & $\begin{array}{r}\text { Chlori } \\
\text { dissolv } \\
\text { (mg/l } \\
\text { as c }\end{array}$ & $\begin{array}{l}\text { ide, } \\
\text { ved } \\
\text { cl) }\end{array}$ & $\begin{array}{r}\text { Fluo } \\
\text { disso } \\
\text { (mg } \\
\text { as }\end{array}$ & $\begin{array}{l}\text { ide, } \\
\text { lved } \\
\text { /L } \\
\text { F) }\end{array}$ & $\begin{array}{r}\text { Sili } \\
\text { dissc } \\
\text { (ms } \\
\text { as }\end{array}$ & $\begin{array}{l}\text { ica, } \\
\text { olved } \\
\left.\text { g/L } / \mathrm{LiO}_{2}\right)\end{array}$ & $\begin{array}{l}\text { Solids } \\
\text { residue } \\
\text { at } 180 \\
\text { deg. C } \\
\text { dissolved } \\
\text { (mg/L) }\end{array}$ \\
\hline $\begin{array}{l}\text { Cd23-14 } \\
\text { cd23-15 } \\
\text { cd42-17 } \\
\text { cd42-17 } \\
\text { cd43- } 4\end{array}$ & $\begin{array}{r}260 \\
59 \\
34 \\
38 \\
110\end{array}$ & $\begin{array}{l}6.5 \\
5.6 \\
3.0 \\
3.2 \\
4.0\end{array}$ & & & $\begin{array}{r}61 \\
-2 \\
92 \\
49 \\
104\end{array}$ & & $\begin{array}{r}780 \\
1,500 \\
54 \\
42 \\
76\end{array}$ & $\begin{array}{r}350 \\
120 \\
74 \\
84 \\
170\end{array}$ & & $\begin{array}{l}<0 . \\
<0 . \\
<0 . \\
<0 . \\
<0 .\end{array}$ & & & 11 & $\begin{array}{r}1,710 \\
2,720 \\
278 \\
253 \\
533\end{array}$ \\
\hline $\begin{array}{l}\operatorname{cd} 43-3 \\
\operatorname{cd} 44-16 \\
\operatorname{cd} 51-15 \\
\operatorname{cd5} 52-27 \\
\operatorname{cd} 52-27\end{array}$ & $\begin{array}{c}170 \\
150 \\
6.3 \\
14 \\
10\end{array}$ & $\begin{array}{l}5.3 \\
6.3 \\
2.4 \\
1.3 \\
1.2\end{array}$ & & & $\begin{array}{r}141 \\
161 \\
110 \\
83 \\
29\end{array}$ & & $\begin{array}{c}160 \\
42 \\
22 \\
11 \\
4.4\end{array}$ & $\begin{array}{r}290 \\
290 \\
12 \\
28 \\
20\end{array}$ & & $\begin{array}{l}<0 \\
0 . \\
<0 \\
<0 \\
<0\end{array}$ & & & & \begin{tabular}{r}
883 \\
-- \\
\hdashline- \\
112 \\
78
\end{tabular} \\
\hline $\begin{array}{l}\text { Cd52-28 } \\
\text { Cd53- } 1 \\
\text { Dc14-43 } \\
\text { Dc15-18 } \\
\text { Dc24-18 }\end{array}$ & $\begin{array}{c}12 \\
190 \\
5.9 \\
18 \\
25\end{array}$ & $\begin{array}{l}2.7 \\
5.9 \\
2.0 \\
1.3 \\
1.4\end{array}$ & & 8.0 & $\begin{array}{r}2 . \\
56 \\
4 . \\
49 \\
34\end{array}$ & & $\begin{array}{l}27 \\
63 \\
11 \\
4.4 \\
5.2\end{array}$ & $\begin{array}{r}21 \\
400 \\
10 \\
40 \\
55\end{array}$ & & $\begin{array}{l}<0 . \\
0 . \\
<0 \\
<0\end{array}$ & & & $\begin{array}{l}15 \\
14 \\
9.7 \\
12.7 \\
10\end{array}$ & $\begin{array}{c}-. \\
124 \\
165\end{array}$ \\
\hline $\begin{array}{l}\text { Dc24-41 } \\
\text { Dc24-41 } \\
\text { Dc25-27 } \\
\text { Dc25-27 } \\
\text { Dc33- } 7\end{array}$ & $\begin{array}{l}5.0 \\
5.1 \\
30 \\
29 \\
5.0\end{array}$ & $\begin{array}{l}1.2 \\
1.4 \\
1.5 \\
1.4 \\
1.3\end{array}$ & & $\begin{array}{l}8.0 \\
6.0 \\
0 \\
0 \\
6.0\end{array}$ & $\begin{array}{r}39 \\
18 \\
77 \\
490 \\
73\end{array}$ & & $\begin{array}{l}2.0 \\
3.8 \\
7.5 \\
5.9 \\
10\end{array}$ & $\begin{array}{r}12 \\
13 \\
64 \\
56 \\
8 .\end{array}$ & & $\begin{array}{l}<0 . \\
<0 . \\
<0 . \\
<0 .\end{array}$ & & & $\begin{array}{l}10 \\
10 \\
11 \\
1 \\
10\end{array}$ & $\begin{array}{r}80 \\
67 \\
187 \\
167 \\
72\end{array}$ \\
\hline $\begin{array}{l}\text { Dc33- } 7 \\
\text { Dc34- } 7 \\
\text { Ec15-28 } \\
\text { Ec22- } 3 \\
\text { P1OA }\end{array}$ & $\begin{array}{l}6.1 \\
3.2 \\
47 \\
3.3 \\
47\end{array}$ & $\begin{array}{l}1.3 \\
.9 \\
2.8 \\
2.4 \\
3.0\end{array}$ & & & $\begin{array}{r}46 \\
138 \\
5 \\
40 \\
16\end{array}$ & & $\begin{array}{c}1.3 \\
11^{1.3} \\
12^{4.6}\end{array}$ & $\begin{array}{c}11 \\
4 . \\
19 \\
2 . \\
17\end{array}$ & & $\begin{array}{r}<0 . \\
<0 . \\
0 . \\
0 . \\
0 .\end{array}$ & & & $\begin{array}{l}10 \\
10 \\
7.8 \\
8.8 \\
8.1\end{array}$ & $\begin{array}{r}59 \\
60 \\
137 \\
83 \\
143\end{array}$ \\
\hline
\end{tabular}




\begin{tabular}{|c|c|c|c|c|c|c|c|c|c|}
\hline $\begin{array}{l}\text { Pump or } \\
\text { flow period } \\
\text { prior to } \\
\text { sampling } \\
\text { (min) }\end{array}$ & $\begin{array}{l}\text { Flow } \\
\text { rate } \\
\text { instan- } \\
\text { taneous } \\
\text { (gal/min) }\end{array}$ & $\begin{array}{l}\text { Specific } \\
\text { conduct- } \\
\text { ance } \\
\text { (us/cm) }\end{array}$ & $\begin{array}{l}\text { pH } \\
\text { (stand- } \\
\text { ard } \\
\text { units) }\end{array}$ & $\begin{array}{l}\text { Tempera- } \\
\text { ture } \\
\text { (Deg } \\
\text { C) }\end{array}$ & $\begin{array}{c}\text { Hardness } \\
(\mathrm{mg} / \mathrm{L} \\
\mathrm{as} \\
\left.\mathrm{CaCO}_{3}\right)\end{array}$ & $\begin{array}{c}\text { Hardness } \\
\text { noncar- } \\
\text { bonate } \\
(\mathrm{mg} / \mathrm{L} \\
\left.\mathrm{CaCO}_{3}\right)\end{array}$ & $\begin{array}{l}\text { Calcium, } \\
\text { dissolved } \\
\text { (mg/L } \\
\text { as Ca) }\end{array}$ & $\begin{array}{l}\text { Magnesium, } \\
\text { dissolved } \\
\text { (mg/L } \\
\text { as Mg) }\end{array}$ & $\begin{array}{l}\text { Well } \\
\text { No. }\end{array}$ \\
\hline $\begin{array}{l}30 \\
15 \\
30 \\
60 \\
60\end{array}$ & $\begin{array}{r}25 \\
90 \\
333 \\
300 \\
400\end{array}$ & $\begin{array}{r}2,550 \\
2,600 \\
410 \\
445 \\
880\end{array}$ & $\begin{array}{l}6.8 \\
4.4 \\
5.6 \\
5.6 \\
5.7\end{array}$ & $\begin{array}{l}17.0 \\
20.0 \\
15.0 \\
16.0 \\
14.0\end{array}$ & $\begin{array}{r}410 \\
470 \\
93 \\
95 \\
100\end{array}$ & $\begin{array}{r}210 \\
74 \\
85 \\
76\end{array}$ & $\begin{array}{r}83 \\
110 \\
19 \\
20 \\
18\end{array}$ & $\begin{array}{l}49 \\
48 \\
11 \\
11 \\
14\end{array}$ & $\begin{array}{l}\text { Cd23-14 } \\
\text { cd23-15 } \\
\text { cd42-17 } \\
\text { cdd2-17 } \\
\text { cd43- } 4\end{array}$ \\
\hline $\begin{array}{r}25 \\
120 \\
>60 \\
30 \\
60\end{array}$ & $\begin{array}{l}595 \\
7.0 \\
100 \\
240 \\
400\end{array}$ & $\begin{array}{r}1,340 \\
1,280 \\
146 \\
167 \\
138\end{array}$ & $\begin{array}{l}5.6 \\
5.9 \\
5.2 \\
5.6 \\
5.9\end{array}$ & $\begin{array}{l}17.0 \\
17.0 \\
15.0 \\
16.0 \\
13.5\end{array}$ & $\begin{array}{r}190 \\
190 \\
49 \\
32 \\
29\end{array}$ & $\begin{array}{r}160 \\
120 \\
37 \\
15 \\
17\end{array}$ & $\begin{array}{c}35 \\
21 \\
10 \\
8.1 \\
7.3\end{array}$ & $\begin{array}{l}24 \\
33 \\
5.0 \\
2.9 \\
2.6\end{array}$ & $\begin{array}{l}\text { Cd43- } 3 \\
\operatorname{cds4-16} \\
\operatorname{cds} 5-15 \\
\operatorname{cs} 52-27 \\
\operatorname{cd} 52-27\end{array}$ \\
\hline $\begin{array}{r}>60 \\
90 \\
>60 \\
25 \\
60\end{array}$ & $\begin{array}{c}200 \\
10 \\
150 \\
7.0 \\
150\end{array}$ & $\begin{array}{r}225 \\
1,490 \\
129 \\
200 \\
252\end{array}$ & $\begin{array}{l}7.0 \\
6.0 \\
6.8 \\
5.5 \\
5.6\end{array}$ & $\begin{array}{l}14.0 \\
17.0 \\
14.0 \\
14.5 \\
14.0\end{array}$ & $\begin{array}{r}63 \\
210 \\
36 \\
32 \\
36\end{array}$ & $\begin{array}{r}49 \\
180 \\
22 \\
24 \\
29\end{array}$ & $\begin{array}{l}13 \\
33 \\
7.6 \\
8.0 \\
8.3\end{array}$ & $\begin{array}{r}7.4 \\
30 \\
4.2 \\
3.0 \\
3.7\end{array}$ & $\begin{array}{l}\operatorname{Cds} 2-28 \\
\operatorname{Cd} 53-1 \\
\operatorname{Dc} 14-43 \\
\operatorname{Dc} 5.18 \\
\operatorname{Dc} 24-18\end{array}$ \\
\hline $\begin{array}{l}30 \\
60 \\
30 \\
60 \\
30\end{array}$ & $\begin{array}{l}112 \\
200 \\
200 \\
200 \\
800\end{array}$ & $\begin{array}{r}93 \\
102 \\
280 \\
259 \\
82\end{array}$ & $\begin{array}{l}5.6 \\
5.8 \\
5.4 \\
5.5 \\
5.2\end{array}$ & $\begin{array}{l}15.0 \\
14.0 \\
15.0 \\
14.0 \\
16.0\end{array}$ & $\begin{array}{l}23 \\
27 \\
39 \\
38 \\
19\end{array}$ & $\begin{array}{l}15 \\
21 \\
29 \\
13 \\
13\end{array}$ & $\begin{array}{l}5.3 \\
6.2 \\
9.9 \\
9.8 \\
4.6\end{array}$ & $\begin{array}{l}2.3 \\
2.8 \\
3.4 \\
3.3 \\
1.8\end{array}$ & $\begin{array}{l}\text { Dc24-41 } \\
\text { Dc24-41 } \\
\text { Dc25-27 } \\
\text { DC25-27 } \\
\text { Dc33- } 7\end{array}$ \\
\hline $\begin{array}{r}30 \\
180 \\
30 \\
30 \\
60\end{array}$ & $\begin{array}{l}800 \\
65 \\
300 \\
175\end{array}$ & $\begin{array}{l}94 \\
53 \\
293 \\
146 \\
253\end{array}$ & $\begin{array}{l}5.7 \\
5.1 \\
7.3 \\
6.5 \\
7.0\end{array}$ & $\begin{array}{l}14.0 \\
16.0 \\
17.0 \\
17.0 \\
14.5\end{array}$ & $\begin{array}{l}22 \\
11 \\
14 \\
45 \\
17\end{array}$ & $\begin{array}{l}10 \\
2 \\
\therefore \\
\therefore \\
. .\end{array}$ & $\begin{array}{r}5.2 \\
2.6 \\
4.0 \\
13 \\
4.7\end{array}$ & $\begin{array}{l}2.1 \\
1.2 \\
3.98 \\
1.2\end{array}$ & $\begin{array}{l}\text { Dc33- } 7 \\
\text { Dcc34-7 } \\
E c 15-28 \\
\text { Ec22- } 3 \\
\text { P10A }\end{array}$ \\
\hline
\end{tabular}

\begin{tabular}{|c|c|c|c|c|c|c|c|c|c|}
\hline $\begin{array}{l}\text { Solids } \\
\text { sum of } \\
\text { constit- } \\
\text { uents, } \\
\text { dissolved } \\
\text { (mg/L) }\end{array}$ & $\begin{array}{l}\text { Solids } \\
\text { dis- } \\
\text { solved } \\
\text { (ton per } \\
\text { ac-at) }\end{array}$ & $\begin{array}{l}\text { Nitrogen } \\
\text { NO2 + NO3 } \\
\text { dissolved } \\
\text { (mg/L } \\
\text { as N) }\end{array}$ & $\begin{array}{l}\text { Phosphorous } \\
\text { ortho, } \\
\text { dissolved } \\
\text { (mg/L } \\
\text { as P) }\end{array}$ & $\begin{array}{l}\text { Phosphate } \\
\text { ortho, } \\
\text { dissolved } \\
\text { (mg/L } \\
\text { as } \mathrm{PO}_{4} \text { ) }\end{array}$ & $\begin{array}{l}\text { Boron, } \\
\text { dissolved } \\
\text { (ug/L } \\
\text { as B) }\end{array}$ & $\begin{array}{l}\text { Iron } \\
\text { dissolved } \\
\text { (ug/L } \\
\text { as Fe) }\end{array}$ & $\begin{array}{l}\text { Manganese, } \\
\text { dissolved } \\
\text { (ug/L } \\
\text { as Mn) }\end{array}$ & $\begin{array}{l}\text { Strontium, } \\
\text { dissolved } \\
\text { (ug/L } \\
\text { as } S r \text { ) }\end{array}$ & $\begin{array}{l}\text { Well } \\
\text { No. }\end{array}$ \\
\hline $\begin{array}{r}1,700 \\
-- \\
220 \\
220 \\
420\end{array}$ & $\begin{array}{l}2.3 \\
3.7 \\
0.33 \\
0.34 \\
0.72\end{array}$ & $\begin{array}{l}1.30 \\
0.14 \\
3.30 \\
3.90 \\
2.80\end{array}$ & $\begin{aligned}<0.01 \\
<0.01 \\
<0.01 \\
<0.01 \\
0.16\end{aligned}$ & $\begin{array}{c}- \\
- \\
- \\
0.49\end{array}$ & $\begin{array}{r}50 \\
30 \\
<20 \\
<20 \\
60\end{array}$ & $\begin{array}{r}110,000 \\
430,000 \\
50 \\
10 \\
12\end{array}$ & $\begin{array}{r}38,000 \\
54,000 \\
50 \\
45 \\
950\end{array}$ & $\begin{array}{l}410 \\
570 \\
180 \\
180 \\
160\end{array}$ & $\begin{array}{l}\text { Cd23-14 } \\
\text { Cd23-15 } \\
\text { Cd42- }-17 \\
\text { Cd22-17 } \\
\text { cd43- } 4\end{array}$ \\
\hline $\begin{array}{r}720 \\
640 \\
78 \\
89 \\
67\end{array}$ & $\begin{array}{l}1.2 \\
0.81 \\
0.11 \\
0.15 \\
0.11\end{array}$ & $\begin{array}{l}2.30 \\
2.00 \\
4.50 \\
2.00\end{array}$ & $\begin{array}{r}0.02 \\
<0.01 \\
0.61 \\
0.02\end{array}$ & $\begin{array}{c}0.06 \\
. . \\
1.9 \\
0.06\end{array}$ & $\begin{array}{r}50 \\
70 \\
- \\
20 \\
<20\end{array}$ & $\begin{array}{r}14 \\
41,000 \\
150 \\
1,800 \\
2,100\end{array}$ & $\begin{array}{r}2,700 \\
1,000 \\
18 \\
27 \\
35\end{array}$ & $\begin{array}{l}300 \\
\because \\
\ddot{84} \\
71\end{array}$ & $\begin{array}{l}\operatorname{cd} 43-3 \\
\operatorname{cds} 4-16 \\
\operatorname{cds} 5-15 \\
\operatorname{cds} 2-27 \\
\operatorname{cd} 52-27\end{array}$ \\
\hline $\begin{array}{r}110 \\
760 \\
59 \\
93 \\
110\end{array}$ & $\begin{array}{l}0.14 \\
1.0 \\
0.08 \\
0.17 \\
0.22\end{array}$ & $\begin{array}{l}3.70 \\
2.10 \\
1.90 \\
2.60\end{array}$ & $\begin{array}{l}<0.01 \\
<0.01 \\
<0.01 \\
<0.01\end{array}$ & $\begin{array}{l}\cdots \\
\cdots \\
\cdots \\
\cdots\end{array}$ & $\begin{array}{r}70 \\
40 \\
<20 \\
<20\end{array}$ & $\begin{array}{r}3 \\
1,600 \\
10 \\
500 \\
11\end{array}$ & $\begin{array}{r}3 \\
220 \\
3 \\
30 \\
3\end{array}$ & $\begin{array}{l}-. \\
\because \\
87 \\
91\end{array}$ & $\begin{array}{l}\text { Cd52-28 } \\
\text { C553- } \\
\text { Dd14-43 } \\
\text { Dd15-18 } \\
\text { Dc24-18 }\end{array}$ \\
\hline $\begin{array}{r}45 \\
47 \\
130 \\
120 \\
55\end{array}$ & $\begin{array}{l}0.11 \\
0.09 \\
0.25 \\
0.23 \\
0.1\end{array}$ & $\begin{array}{l}1.40 \\
3.50 \\
2.10 \\
1.70 \\
3.00\end{array}$ & $\begin{aligned}<0.01 \\
<0.01 \\
<0.01 \\
0.15 \\
0.01\end{aligned}$ & $\begin{array}{c}\ldots \\
\because \\
0.46 \\
0.03\end{array}$ & $\begin{array}{l}<20 \\
<20 \\
<20 \\
20 \\
30\end{array}$ & $\begin{array}{r}9 \\
6 \\
17 \\
20 \\
8\end{array}$ & $\begin{array}{r}4 \\
4 \\
34 \\
30 \\
3\end{array}$ & $\begin{array}{r}57 \\
64 \\
120 \\
110 \\
54\end{array}$ & $\begin{array}{l}\text { Dc2 } 24-41 \\
\text { DC24-41 } \\
\text { Dc25-27 } \\
\text { DC25-27 } \\
\text { DC33- } 7\end{array}$ \\
\hline $\begin{array}{r}42 \\
150 \\
76 \\
750 \\
150\end{array}$ & $\begin{array}{l}0.08 \\
0.08 \\
0.19 \\
0.11 \\
0.19\end{array}$ & $\begin{array}{r}3.20 \\
1.70 \\
<0.10 \\
<0.10 \\
<0.10\end{array}$ & $\begin{aligned}<0.01 \\
<0.01 \\
0.04 \\
0.03 \\
0.01\end{aligned}$ & $\begin{array}{c}\because \\
0.12 \\
0.09 \\
0.03\end{array}$ & $\begin{array}{r}<20 \\
<20 \\
90 \\
20 \\
90\end{array}$ & $\begin{array}{r}6 \\
19 \\
1,100 \\
9,200 \\
1,100\end{array}$ & $\begin{array}{r}1 \\
2 \\
17 \\
100 \\
<1\end{array}$ & $\begin{array}{r}32 \\
110 \\
220 \\
120\end{array}$ & $\begin{array}{l}\text { Dc33- } \\
\text { DC344- } \\
\text { Ec15-28 } \\
\text { Ec22- } \\
\text { P10A }\end{array}$ \\
\hline
\end{tabular}


character. Background water quality in the Potomac aquifers near Army Creek landfill (location in fig. 17) was dominated by calcium, magnesium, and chloride (Baedecker and Back, 1979, p. 433).

The ambient water quality depends on the quality of precipitation infiltrating the outcrop areas and subsequent reactions between the ground water and aquifer material. Rainfall in the coastal areas commonly contains low concentrations (less than $10 \mathrm{mg} / \mathrm{L}$ ) of sodium, chloride, and sulfate, but relatively high amounts of dissolved gases. The water infiltrates through the soil zone and accumulates additional carbon dioxide $\left(\mathrm{CO}_{2}\right)$ and then reacts with the nonmarine sand, silt, and clay of the Potomac Formation. The sand is predominantly quartz with some feldspar, mica, and contains lenses of ferric-oxyhydroxides (iron cement). All of these minerals, except for quartz, are fairly reactive in the ground-water system. Other reactive aquifer material includes illite clay, lignite and other organic matter, pyrite, and dissolved gases. The water quality of the ambient ground water is a result of several geochemical processes. The reaction between the silicate minerals (feldspar, mica, and quartz) and the recharge water produces dissolved ions, principally calcium, magnesium, sodium, potassium, silica, bicarbonate, and a residual solid phase (kaolinite). The dissolved oxygen in the ground water also will oxidize the lignite and pyrite associted with the clay to produce dissolved iron, sulfate, and bicarbonate. The dissolved iron is stable in a reducing environment, but will precipitate to form iron cement if exposed to dissolved oxygen.

Figure 15 reveals that some chloride concentrations greatly exceed that of the ambient ground water (10 to $21 \mathrm{mg} / \mathrm{L}$ ), ranging from 40 to $8,600 \mathrm{mg} / \mathrm{L}$. Water from two we11s, Cd44-16 and Cd53-1, located in the Columbia aquifer underlying the Delaware River, have chloride values of 290 and $400 \mathrm{mg} / \mathrm{L}$, respectively. Figure 16 indicates that the analyses with chloride concentrations above $40 \mathrm{mg} / \mathrm{L}$ (1isted under degradated ground water) plot close to sodium and potassium in the cation field and towards chloride in the anion field. Specific conductance ranges from 200 to $1,490 \mu \mathrm{S} / \mathrm{cm}$. These data points indicate a sodium potassium-chloride type water which is distinctly different from the ambient water quality.

Data shown in figures 15 and 16 indicate other sources have degraded the water quality in the uppermost Potomac aquifer. Two sources of groundwater degradation are infiltration from the Delaware River and seepage of leachate from waste-disposal sites. The locations of areas affected by infiltration of river water and waste-disposal sites are shown in figure 17. These areas represent an estimate of the areal distribution of degraded ground water based on available data. Data documenting the areas of groundwater degradation shown in figure 17 are presented later in the report.

\section{Delaware River}

Water from the Delaware River is seasonally brackish; thus infiltration of river water poses a threat to the quality of freshwater in the aquifers. The amount of saltwater in the Delaware River at any location depends on (1) the distance from the ocean, (2) the freshwater flow of the river, (3) the quantity of salty water moving upstream from the ocean, (4) the stage of tide, (5) the range of tide (Cohen, 1957, p. 1), and (6) the depth of water. 


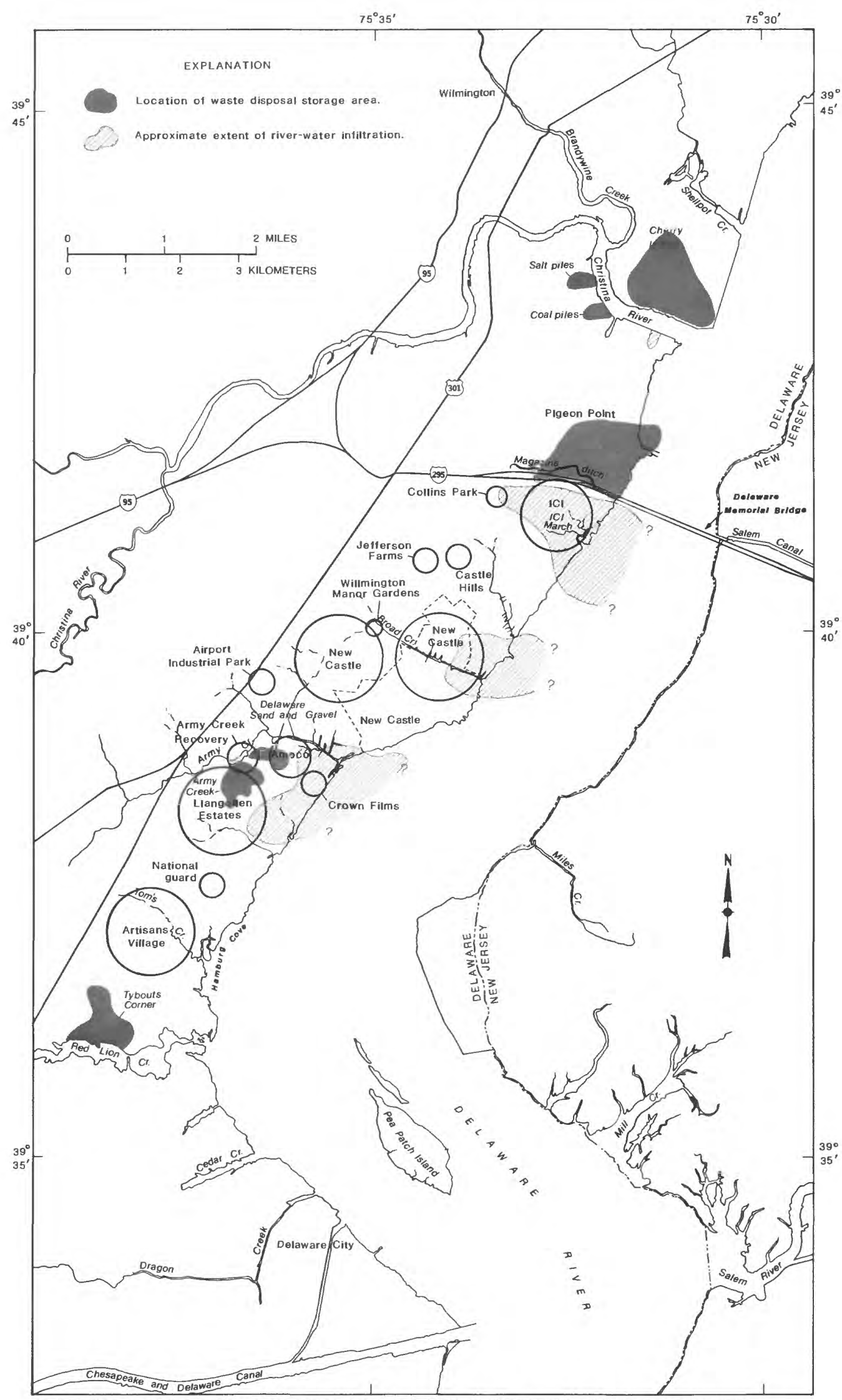

BASE FROM U.S. GEOLOGICAL SURVEY, 1:24.000 OELAWARE CITY, ST. GEORGES, WILMINGTON SOUTH, AND NEWARK EAST OUADRANGLES. infiltration of river water in the uppermost Potomac aquifer. 
Figure 18 is a plot of changes in chloride concentration over time at the Memorial Bridge. The seasonal variation of the brackish-water movement is readily apparent. Chloride concentrations are as low as $10 \mathrm{mg} / \mathrm{L}$ during April and May, reflecting increased freshwater inflow during the spring. The decrease of freshwater inflow during the summer causes chloride concentrations to increase, commonly from 300 to $800 \mathrm{mg} / \mathrm{L}$ during August through October. Cohen and McCarthy (1963, p. B1) noted that the most favorable conditions for upstream saltwater movement occur from August to early October, and the least favorable conditions occur between December and May. The magnitude of the chloride peaks reflect flow conditions in the Delaware River basin. Maximum chloride concentrations ranged from 2,500 to 3,300 $\mathrm{mg} / \mathrm{L}$ from 1963 through 1966, reflective of the drought conditions during that time (fig. 18). Major-ion characterization of the brackish water can be seen on Stiff and Durov diagrams (figs. 15 and 16). Sodium and chloride are the predominant ions of the brackish water.

\section{DEGRADATION OF GROUND-WATER QUALITY} IN THE POTOMAC AQUIFERS

Water-quality data indicate that ground-water degradation is occurring in the Potomac aquifers as a result of the infiltration of river water and seepage of leachate from waste-disposal sites. This section presents evidence for the degradation of ground water by infiltration of water from the Delaware River and how this source of degradation can be differentiated from that caused by leachate from waste-disposal sites. Ground-water degradation in the overlying Columbia aquifer is addressed in cases where it has affected the Potomac aquifers. Figure 17 shows the location of well fields affected by the infiltration of river water. Infiltration into the upper Potomac aquifer is occurring at the Llangollen Estates, Crown Films, and Amoco well fields. Areas affected by infiltration into the middle Potomac aquifer include the New Castle, Collins Park, and ICI well fields. Water-quality data in the lower Potomac aquifer are insufficient to document specific areas of infiltration, except for an occurrence just south of the Wilmington Marine Terminal.

Locations of waste-disposal sites also are shown in figure 17 . Groundwater degradation by leachate from these sites is very localized; however, the proximity of the sites to areas of infiltration of river water warrants discussion. In the lower Potomac aquifer, leachate from waste-disposal sites has caused water-quality degradation in wells Cd23-14, Cd24-9, and 2D (fig. 15). A water-quality analysis from well Cd23-14 (table 3) reveals the presence of elevated iron and sulfate concentrations that are indicative of runoff from adjacent coal piles. The $8,600 \mathrm{mg} / \mathrm{L}$ chloride concentration in well 2D is a result of runoff from a salt storage pile (Weber, Young, and Apgar, 1985). Well Cd24-9 underlies the Cherry Island landfill, and well water had a chloride concentration of $45 \mathrm{mg} / \mathrm{L}$ in 1980 (Gilbert/Commonwealth, 1981). Downward flow from the landfill is the probable source of contamination. Waste-disposal sites overlying the upper and middle Potomac aquifers are addressed in the following sections. 


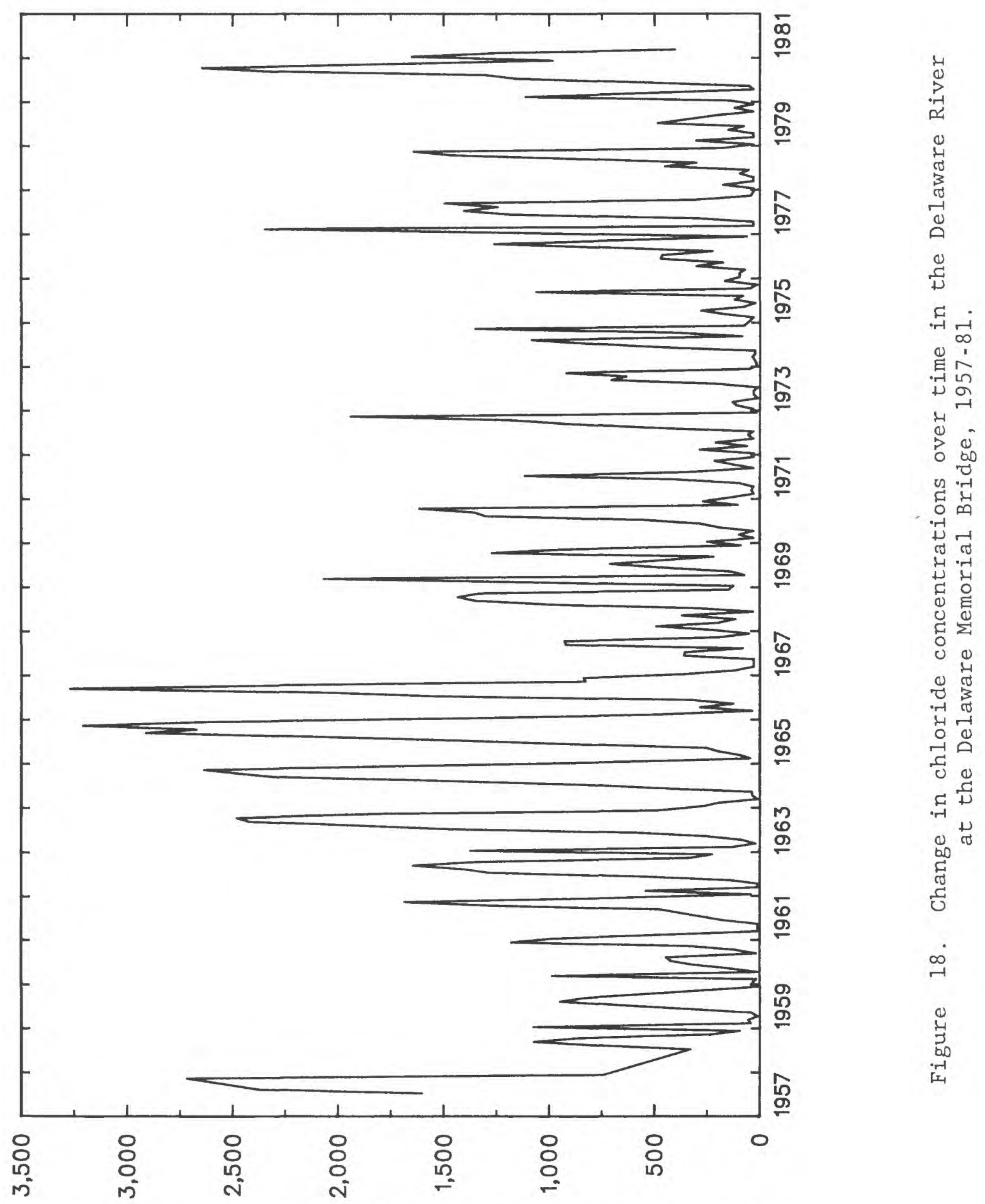

У 


\section{Llangollen Estates--Crown Films--Amoco Well Fields}

Figure 19 shows well locations and isochlors in the vicinity of Llangollen Estates, Crown Films, and Amoco well fields. Withdrawals from the Potomac aquifers at the Crown Films well field began in 1915. Pumpage averaged $1.0 \mathrm{Mgal} / \mathrm{d}$, but decreased to $0.65 \mathrm{Mgal} / \mathrm{d}$ when the plant was remodeled in 1952 (Marine and Rasmussen, 1955, p. 108). The Llangollen Estates well field began operating in 1953. Five production wells located near Route 13 withdrew an estimated $0.9 \mathrm{Mgal} / \mathrm{d}$ in 1952, which increased to an average of $3.5 \mathrm{Mgal} / \mathrm{d}$, with a short-term peak withdrawal rate of 5.2 Mgal/d in 1972 (Sundstrom, 1974, p. 57). The increased withdrawals were from additional production wells located east of Llangollen Estates near the Delaware River. Pumpage was decreased in 1973; current withdrawals are 1.8 Mgal/d (Martin and Denver, 1982, p. 62). In 1973, leachate-recovery we11s began operating near the Army Creek landfill and now withdraw from 1.0 to $3.5 \mathrm{Mgal} / \mathrm{d}$. The Amoco well field began operating in 1961 with two production wells that withdrew a total of about $1.0 \mathrm{Mgal} / \mathrm{d}$ from the upper Potomac aquifer. These wells ceased operation in 1981.

Elevated chloride concentrations in the upper Potomac aquifer within the Amoco well field were observed in 1970 (Geraghty and Miller, 1970, p. 1). The water quality was influenced by leachate from two landfills--Army Creek and Delaware Sand and Gravel--and from infiltration of water from the Delaware River and the Army Creek tributary. The following discussion presents data to identify the sources of the ground-water degradation.

In 1970 , chloride concentrations of 28 and $15 \mathrm{mg} / \mathrm{L}$ were detected in Amoco production wells Dc25-17 and Dc15-10, respectively (Geraghty and Miller, 1970, p. 12). Additional wells were drilled between the production wells and the Army Creek tributary in order to determine the source of the chlorides. Elevated chloride concentrations were found in two wells--Dc1518 and Dc15-20--north of the production we1ls, but not to the south and west. Geraghty and Miller (1970, p. 13) stated that, because the clay overlying the Potomac aquifers had relatively low permeability, it was unlikely that the chloride had moved into the aquifer from the overlying marshes, from the Army Creek tributary, or from the Delaware River. Assuming the clay confining unit was not eroded or missing anywhere near the plant, the most reasonable explanation was that the chloride had been in the clay for centuries and was leaking vertically into the top of the Potomac aquifers because of pumpage (Geraghty and Miller, 1970, p. 13). Two years later, contamination was discovered in wells downgradient from the Army Creek landfill. Studies by Sundstrom (1974, p. 78), Baedecker and Back (1979, p. 431), and Miller (1985) indicated that chloride contamination at the Amoco production wells was from the landfill leachate. However, wells Dc15-18 and Dc15-20, north of the production wells, were most likely contaminated by brackish water infiltrating from the Army Creek tributary and not by landfill leachate or leakage from the clay. This conclusion is based on the following: 


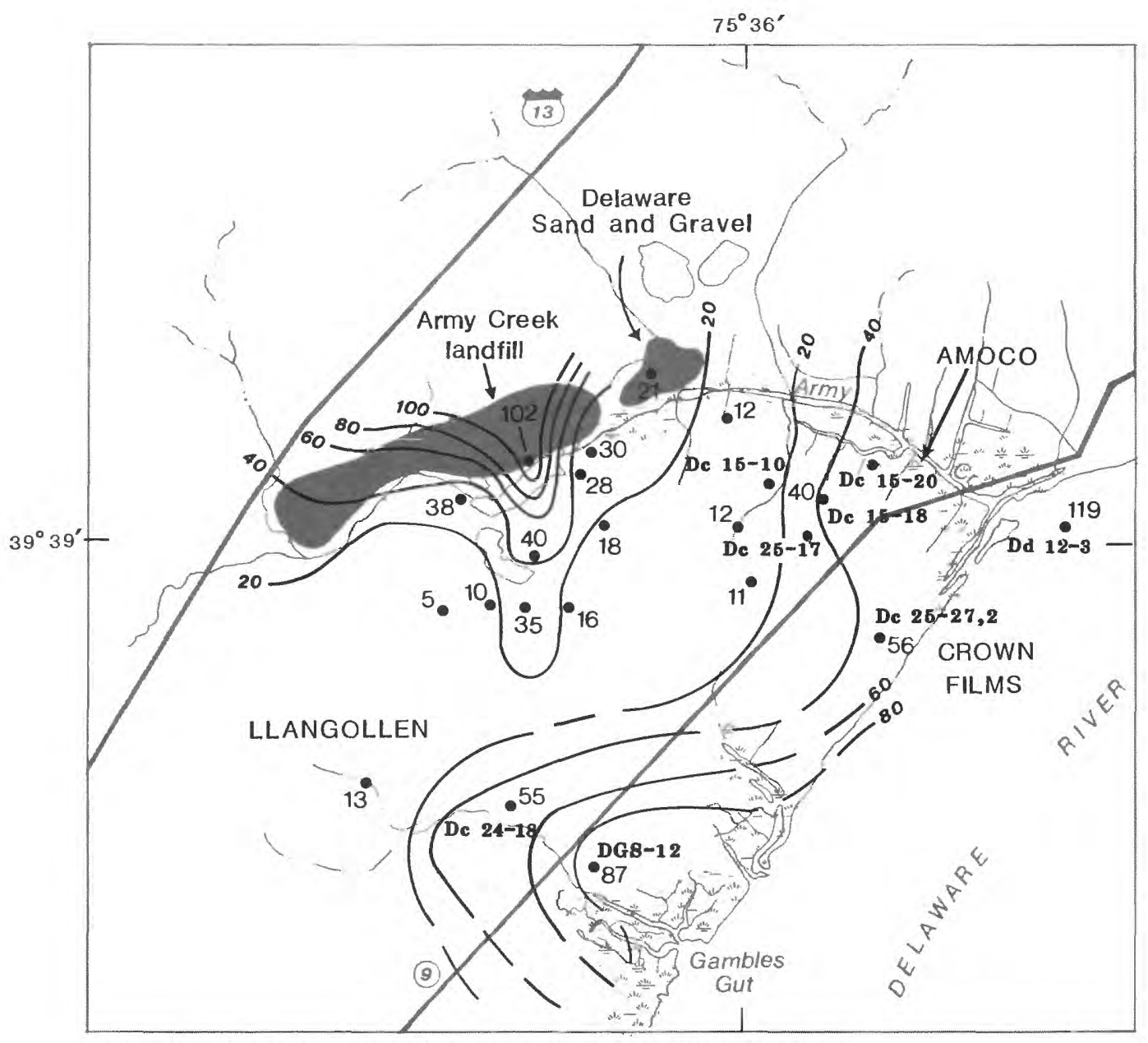

BASE MAP MODIFIED FROM U.S. GEOLOGICAL SURVEY, 1:24,000 WILMINGTON SOUTH, DEL.-N.J. QUADRANGLE

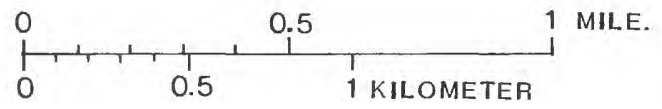

\section{EXPLANATION}

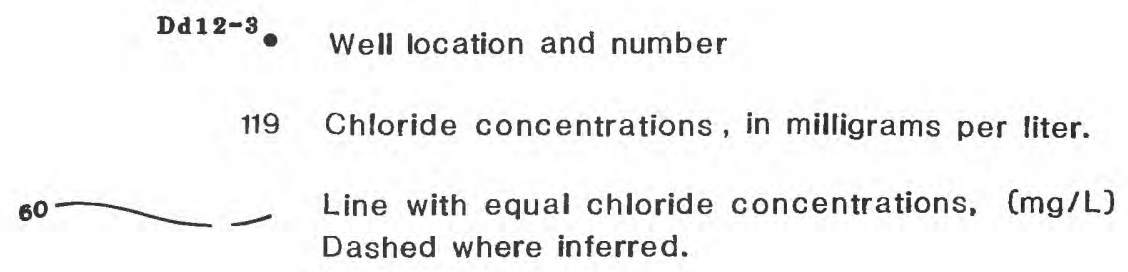

Figure 19. Location of wells in the upper Potomac aquifer and April 1985 isochlors for the Llangollen Estates, Army Creek, Amoco, and Crown Films well fields. (Modified from Miller, 1985, fig. 55.) 
1) Pumpage from wells Dc15-10 and Dc25-17 caused water levels in Dc15-18 and Dc15-19 to fall below sea level (Martin and Denver, 1982, fig. 10), thus establishing a gradient from the Army Creek tributary toward these wells (see fig. 19 for well locations). Additionally, pumpage of wells Dc15-10 and Dc25-17 intercepted leachate from the landfill and prevented it from moving towards Dc15-18 and Dc15-20.

2) The confining unit overlying the Potomac aquifers is less than $20 \mathrm{ft}$ thick in some areas near the Army Creek tributary (Miller, 1985, fig. 3.9). This increases the potential for infiltration into the upper Potomac aquifer.

3) Chloride concentrations measured during April 1985 were $40 \mathrm{mg} / \mathrm{L}$ at wel1 Dc15-18 near the Army Creek tributary; however, chloride concentrations decrease in the direction of the landfills (fig. 19). This situation was observed in aquifer tests run in 1970 and 1975. Chloride values were 147 $\mathrm{mg} / \mathrm{L}$ in we11 Dc15-20, while production wel11 Dc25-17 never exceeded 35 $\mathrm{mg} / \mathrm{L}$ (Geraghty and Miller, 1970, p. C3-4). The isochlors in figure 19 indicate that the source of chlorides is from the Army Creek tributary and not the landfills.

4) Geochemical plots of an analysis from well Dc15-18 reveal a sodiumchloride type water, indicating that the ambient ground water has mixed with a brackish water (figs. 15 and 16).

5) Leakage of saltwater from the Potomac clay (Geraghty and Miller, 1970, p. 13) is unlikely because these sediments were deposited under nonmarine conditions. Any post-deposition saltwater present within the clay probably would have been removed by the freshwater flow system before pumping began.

The data demonstrate that infiltration from the Army Creek tributary has occurred at we11s Dc15-18 and Dc15-20. This infiltration is still occurring, even though the Amoco wells are abandoned, because of pumpage at the Army Creek and Llangollen Estates well fields.

The Crown Films well field is located adjacent to the Delaware River, east of the Amoco site (fig. 19). Chloride concentrations in the upper Potomac aquifer began to increase between 1955 and 1972 (fig. 20). Infiltration of river water is thought to be the source of the chloride. This conclusion is based on the following:

1) Figure 13 indicates during May 1985, heads in the upper Potomac aquifer were at least $20 \mathrm{ft}$ below sea level. Martin and Denver (1982, p. 84) reported historical water levels decreased from $2 \mathrm{ft}$ below sea level in 1955 to $94 \mathrm{ft}$ below sea leve1 in 1966.

2) Gradients in the upper Potomac aquifer from 1973 to 1981 would prevent any landfill leachate from reaching this well field (Baedecker and Apgar, 1984, p. 129)

3) Pleistocene erosion removed some of the Potomac confining unit offshore from the Crown Films well field (fig. 5). 


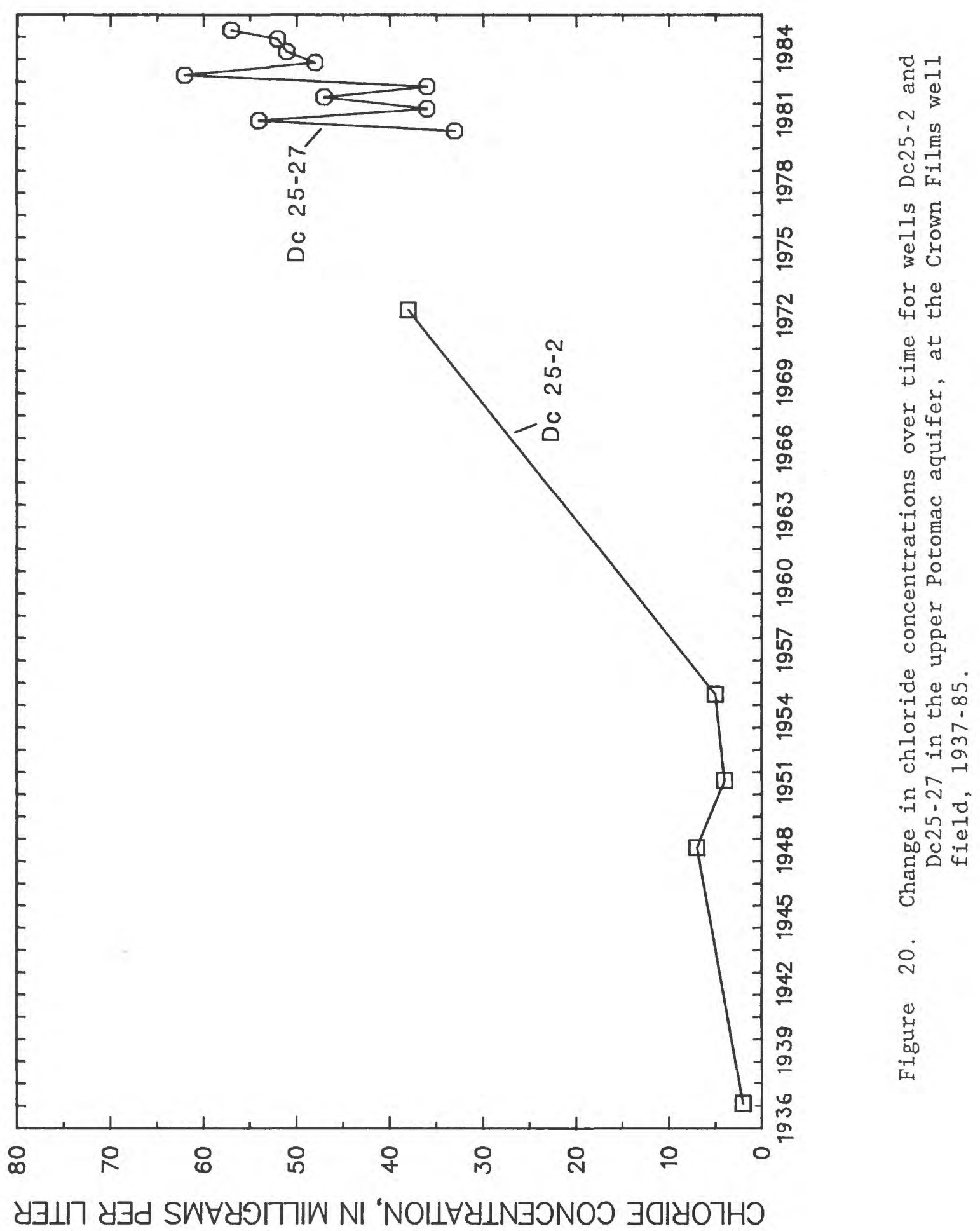


4) Chloride concentrations of pore water in the sediments underlying the river near the Crown Films well field are elevated. Two cores from borehole Ddl1-3 show chloride concentrations of $448 \mathrm{mg} / \mathrm{L}$ and $152 \mathrm{mg} / \mathrm{L}$ in the Holocene sediments (table 2). The Potomac confining unit, which overlies the upper Potomac aquifer, has a chloride concentration of $119 \mathrm{mg} / \mathrm{L}$ table 2). The concentrations suggest downward flow from the river.

5) Analysis from well Dc25-27 reveals a sodium chloride-type water, which indicates mixing with a brackish water (figs. 15 and 16).

The Llangollen Estates well field is located south of the Army Creek landfill (see fig. 19). The western part of the well field may have experienced leachate contamination prior to operation of the Army Creek recovery we1ls. However, the elevated chloride concentrations found in the eastern part of the well field, principally we11 Dc24-18, are a result of the infiltration of river water. This conclusion is based on the following:

1) In May 1985, the potentiometric surface of the upper Potomac aquifer was from 20 to $60 \mathrm{ft}$ below sea level. Water levels have been below sea level at least since 1971 (Martin and Denver, 1982, fig. 44).

2) Figure 21 shows that the chloride concentration in well Dc24-18 rose from $5.0 \mathrm{mg} / \mathrm{L}$ in 1974 to peaks of $480 \mathrm{mg} / \mathrm{L}$ in 1977 . Chloride concentrations from 1978 to 1985 have averaged about $55 \mathrm{mg} / \mathrm{L}$. The elevated chloride peaks occurred after periodic shutdowns of we11 Dc24-18. During operation of the we11, chloride concentrations decreased to 50 to $70 \mathrm{mg} / \mathrm{L}$. Some studies interpret this pattern as pulses of leachate moving through the aquifer. However, this pattern can also be explained by the infiltration of river water. When the well is not operating, all pumpage is located to the west. Thus, leachate is drawn away from we11 Dc24-18, and river water is drawn through the aquifer near we11 Dc24-18. When we11 Dc24-18 is operating, freshwater mixes with the river water and causes a decrease in chloride concentrations. The average chloride concentration of $55 \mathrm{mg} / \mathrm{L}$, which occurred from 1978 to 1985, probably reflects the fact that pumpage and aquifer water levels have shown little change during this period. Pumpage averages about $1.8 \mathrm{Mgal} / \mathrm{d}$, whereas water levels have stayed 40 to $60 \mathrm{ft}$ below sea leve1 (Martin and Denver, 1982, p. 60-62; Andrea Putscher, Delaware Department of Natural Resources and Environmental Control, written commun., 1985).

3) Baedecker and Apgar (1984, p. 132) studied the hydrogeologic processes and chemical reactions occurring around the Army Creek landfill between 1977 and 1981. They plotted the distribution of dissolved oxygen, total organic carbon, nitrate, and $\mathrm{Kjeldahl} \mathrm{nitrogen} \mathrm{to} \mathrm{delineate} \mathrm{leachate}$ migration. Baedecker and Apgar concluded that we11 Dc24-18 was not being affected by leachate.

4) Plots of April 1985 isochlors show a "high" east of Dc24-18 and a decrease towards the landfill, indicative of the infiltration of river 'water (fig. 19).

5) Geochemical plots of an analysis of we11 Dc24-18 indicate a sodium chloride-type water, which plots as a mix between ambient ground water and river water (figs. 15 and 16 ). 


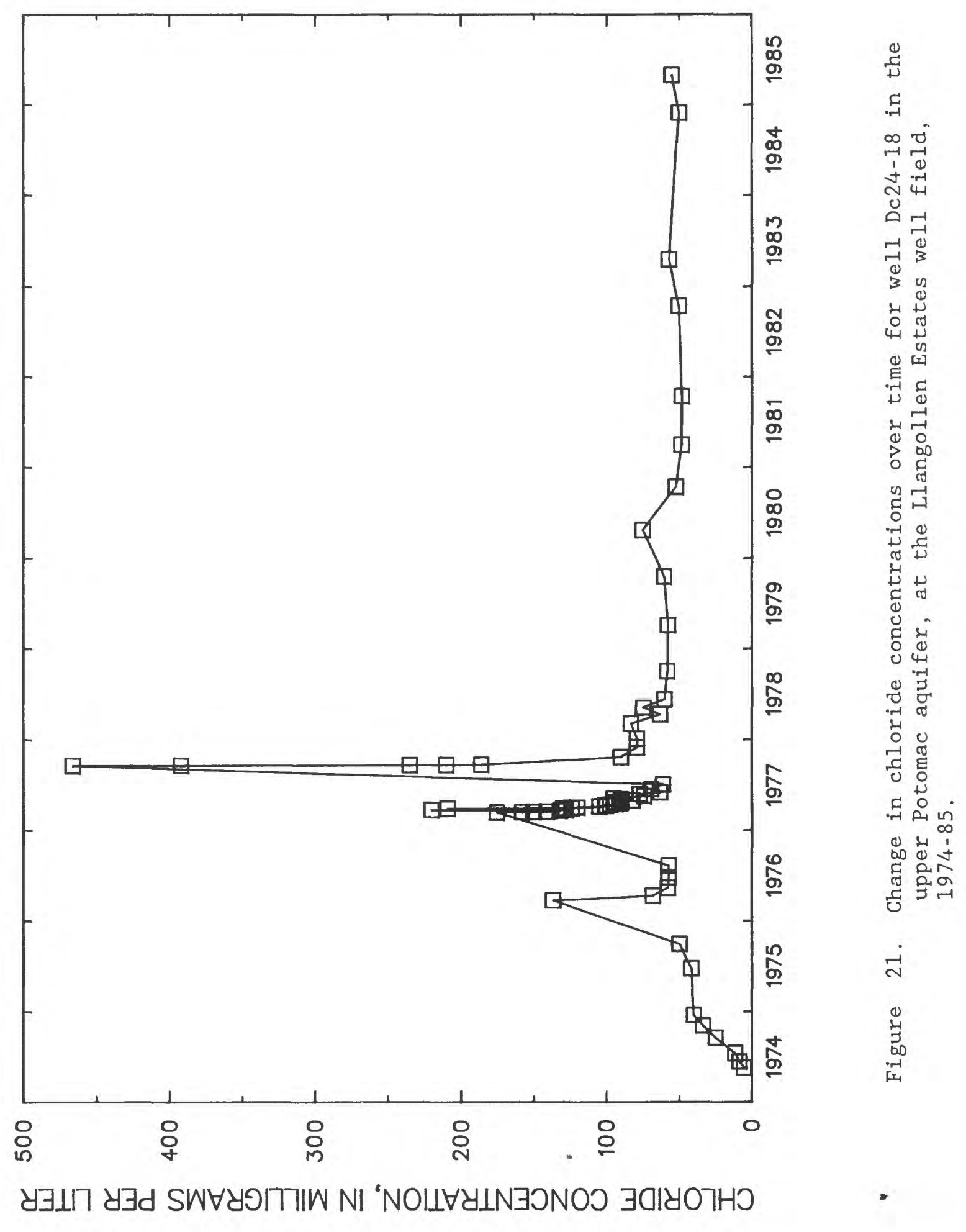


Pumpage in the western New Castle well field is from the upper Potomac aquifer, whereas production in the eastern New Castle well field is from the middle Potomac and Columbia aquifers. Ground-water degradation has occurred in the middle Potomac and Columbia aquifers but not in the upper Potomac aquifer. Sources of ground-water degradation include the fill areas of the Broad Dyke marsh, infiltration of brackish water from Broad Dyke Creek, and infiltration from the Delaware River (fig. 22).

Elevated chloride levels of 98 to $291 \mathrm{mg} / \mathrm{L}$ occurred in several wells in the Columbia aquifer from 1948 through 1956 (Rasmussen and others, 1957, p. 170). Henderson (1951, p. 6-7) had shown a correlation between water levels, pumpage, and chlorides in the Columbia aquifer. As pumpage increased, the water level declined and the chloride concentrations rose. The source of the chloride was the tidal marsh of Broad Dyke Creek (Marine and Rasmussen, 1955, p. 106) or the Delaware River, one-half mile east of the well field (Rasmussen and others, 1957, p. 171) (fig. 22).

The middle Potomac aquifer underlies the Columbia aquifer in the eastern New Castle well field. Well Cd52-13, and later well Cd52-27, withdrew water from the middle Potomac aquifer from 1952 to 1981 . Figure 23 is a plot of chloride concentrations over time for these two wells. The elevated chloride concentrations result from brackish-water infiltration from the Delaware River or Broad Dyke Creek. This is based on the following:

1) Previous pumpage from the middle Potomac aquifer lowered aquifer heads to $100 \mathrm{ft}$ below sea level (Martin and Denver, 1982, p. 57). Heads were still below sea level in May 1985, even though pumpage had ceased 5 years earlier (fig. 14).

2) Figure 6 indicates that part of the Potomac confining unit offshore from New Castle has been eroded and replaced by deposits of permeable sand and gravel. An aquifer test on well Cd52-13 in June 1955 indicated a hydraulic connection between the middle Potomac aquifer and the overlying Columbia aquifer in the vicinity of New Castle (Rasmussen and others, 1957, p. 171).

3) Figure 23 shows that chloride concentrations in the middle Potomac aquifer are a function of pumpage and river salinity. Chloride concentrations averaged less than $5 \mathrm{mg} / \mathrm{L}$ from 1952 to 1963 . The elevated salinity in the Delaware River during the mid-1960's drought is reflected by chloride concentrations increasing from 5 to $22 \mathrm{mg} / \mathrm{L}$ in the well field. The subsequent drop in river salinity following the drought (1968-71) also can be seen in chloride concentrations in the aquifer. Continued withdrawal lowered the aquifer heads and caused a steady chloride increase from 1967 to 1981. Production from the middle Potomac aquifer was stopped in 1981. As a result, the chloride concentrations decreased from 66 to $20 \mathrm{mg} / \mathrm{L}$ from 1981 to 1985.

4) We11 Dd12-3, located closer to the Delaware River than Cd52-27, had a chloride concentration of $65 \mathrm{mg} / \mathrm{L}$ in May 1985 (fig. 15). 


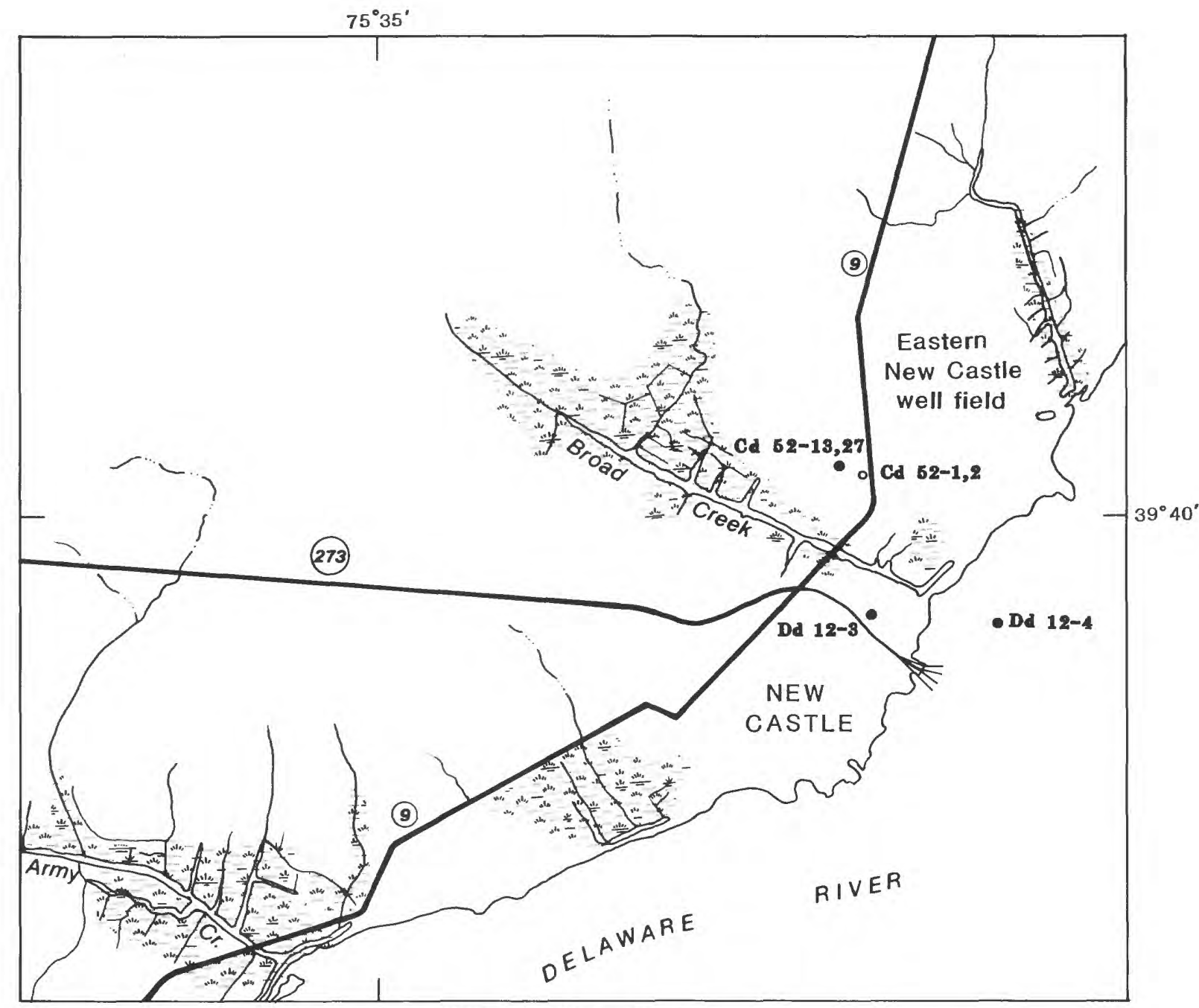

BASE MAP MODIFIED FROM U.S. GEOLOGICAL SURVEY, 1:24,000

WILMINGTON SOUTH, DEL.-N.J. QUADRANGLE

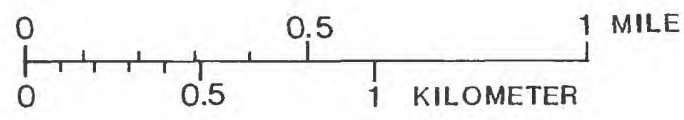

\section{EXPLANATION}

Dd 12-4. Well location and number in the middle Potomac aquifer.

Cd $52-1,2$ Well location and number in the Columbia aquifer.

Figure 22. Location of selected wells in the middle Potomac and Columbia aquifers, at the New Castle well field. 


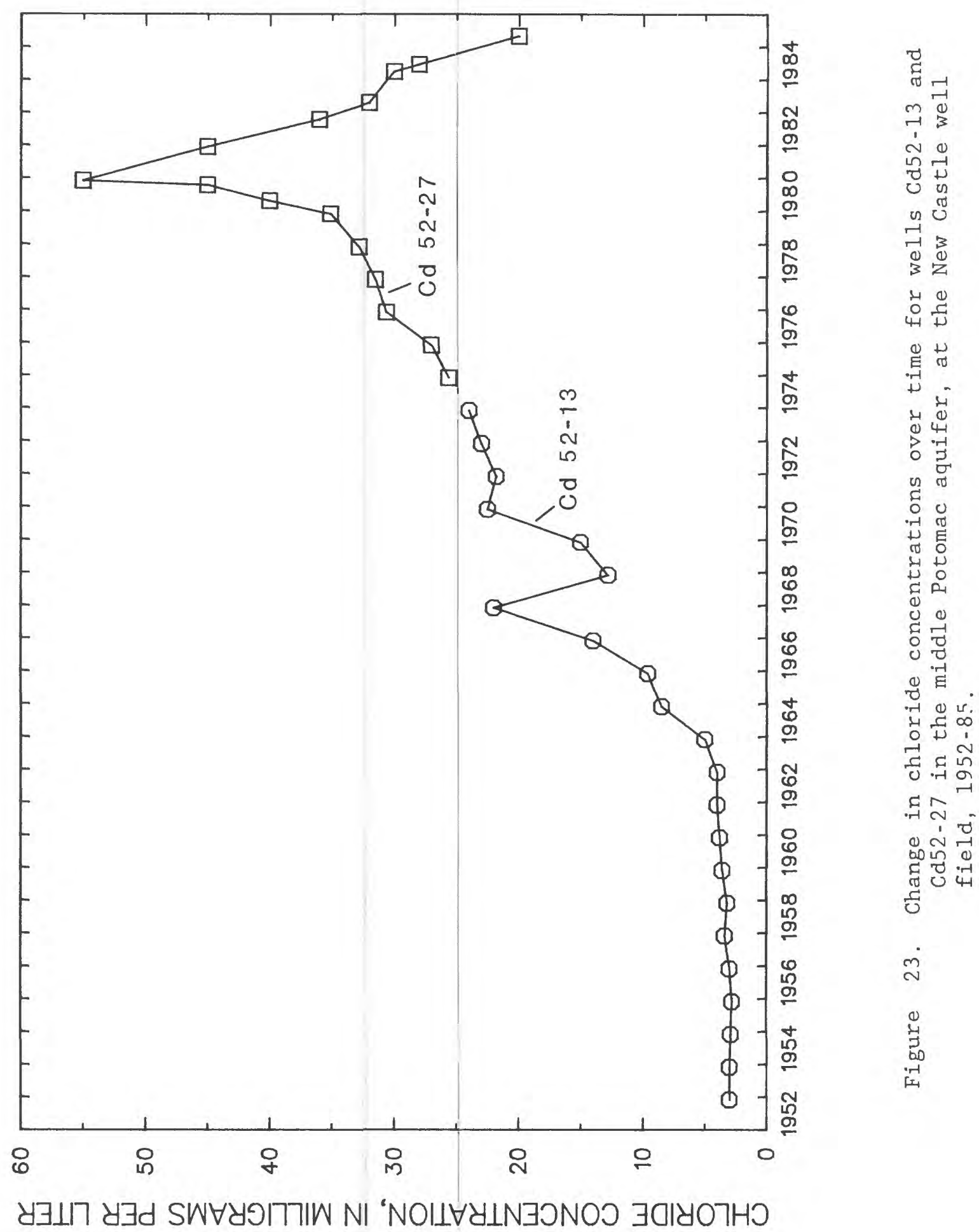


5) Chloride concentrations in interstitial water of the sediments from borehole Dd12-4, which underlie the river offshore from New Castle, are very high. Chloride concentrations in the Holocene sediments range from 643 to $1,273 \mathrm{mg} / \mathrm{L}$, whereas chloride concentrations in the Potomac sediments at 97 to $98.5 \mathrm{ft}$ below sea level are $894 \mathrm{mg} / \mathrm{L}$ (table 2). This suggests downward movement of brackish water from the Delaware River.

6) Geochemical plots of analyses from Cd52-27 and Dd12-3 show a sodium chloride-type water, which suggests mixing of ambient ground water and brackish water (figs. 15 and 16).

\section{Collins Park--ICI Americas Well Fields}

Previous withdrawals from the Collins Park and ICI well fields have been from the middle Potomac and Columbia aquifers (fig. 24). Currently, withdrawals are from the middle Potomac aquifer. Ground-water degradation is evident in both aquifers in the area. Possible sources of degradation include industrial effluent, landfills, and the Delaware River or associated tidal marshes and tributaries. It is difficult to determine the sources of degradation because the historical pumpage has resulted in complex flow patterns. However, various data indicate that the predominant degradation source is the Delaware River and associated marshes and tributaries.

Some evidence exists to discount industrial effluent or landfills as sources of ground-water degradation. Industrial effluent has been discarded through drainage ditches on the ICI property. Chloride concentrations in the effluent are usually not high enough to cause the concentrations observed in the aquifer (David Beattie, ICI Americas, Inc., oral commun., 1985). An aquifer test performed by DNREC in 1978 determined that there was no hydraulic connection between aquifers in the Collins Park-ICI well fields and aquifers underlying the Pigeon Point landfill to the north.

Historical data indicate that infiltration from the Delaware River or associated tidal marshes and tributaries has degraded water in the Columbia aquifer. Elevated chloride concentrations were first observed in wells of the Columbia aquifer located near the river (fig. 24). Chloride concentrations in sampled wells ranged from 21 to $39 \mathrm{mg} / \mathrm{L}$ in 1936 (table 4). Table 4.--Chloride concentrations and screened intervals in wells of the Columbia aquifer
at the ICI Americas well field, for the period $1936-45$

$[f t=f o o t$

$-\quad=a$ dash indicates data not collected]

\begin{tabular}{|c|c|c|c|c|c|c|c|c|c|c|c|}
\hline \multirow{2}{*}{$\begin{array}{l}\text { Well } \\
\text { No. }\end{array}$} & \multirow{2}{*}{$\begin{array}{l}\text { Screened-1/ } \\
\text { interval } \\
(\mathrm{ft})\end{array}$} & \multicolumn{10}{|c|}{ Chloride concentrations, in milligrams per liter } \\
\hline & & $9 / 02 / 36$ & $10 / 07 / 36$ & $11 / 28 / 36$ & $12 / 22 / 41$ & $5 / 06 / 42$ & $3 / 09 / 42$ & $7 / 22 / 43$ & $10 / 11 / 44$ & $4 / 04 / 44$ & $7 / 13 / 45$ \\
\hline Cd43-1 & -22 to -37 & 21 & - & - & 19 & 127 & - & 75 & 106 & - & - \\
\hline Cd43-2 & -31 to -46 & - & 21 & - & - & 86 & - & 210 & 291 & - & - \\
\hline $\operatorname{cd} 43-6$ & -45 to -60 & - & - & - & - & 35 & - & 31 & 35 & 35 & 21 \\
\hline $\operatorname{cd} 43-8$ & -42 to -57 & - & - & 39 & - & 42 & - & 37 & 56 & - & - \\
\hline $\cos 43-9$ & -25 to -40 & - & - & - & - & - & 191 & 104 & 177 & - & - \\
\hline
\end{tabular}

$1 /$ Datum is sea level. 


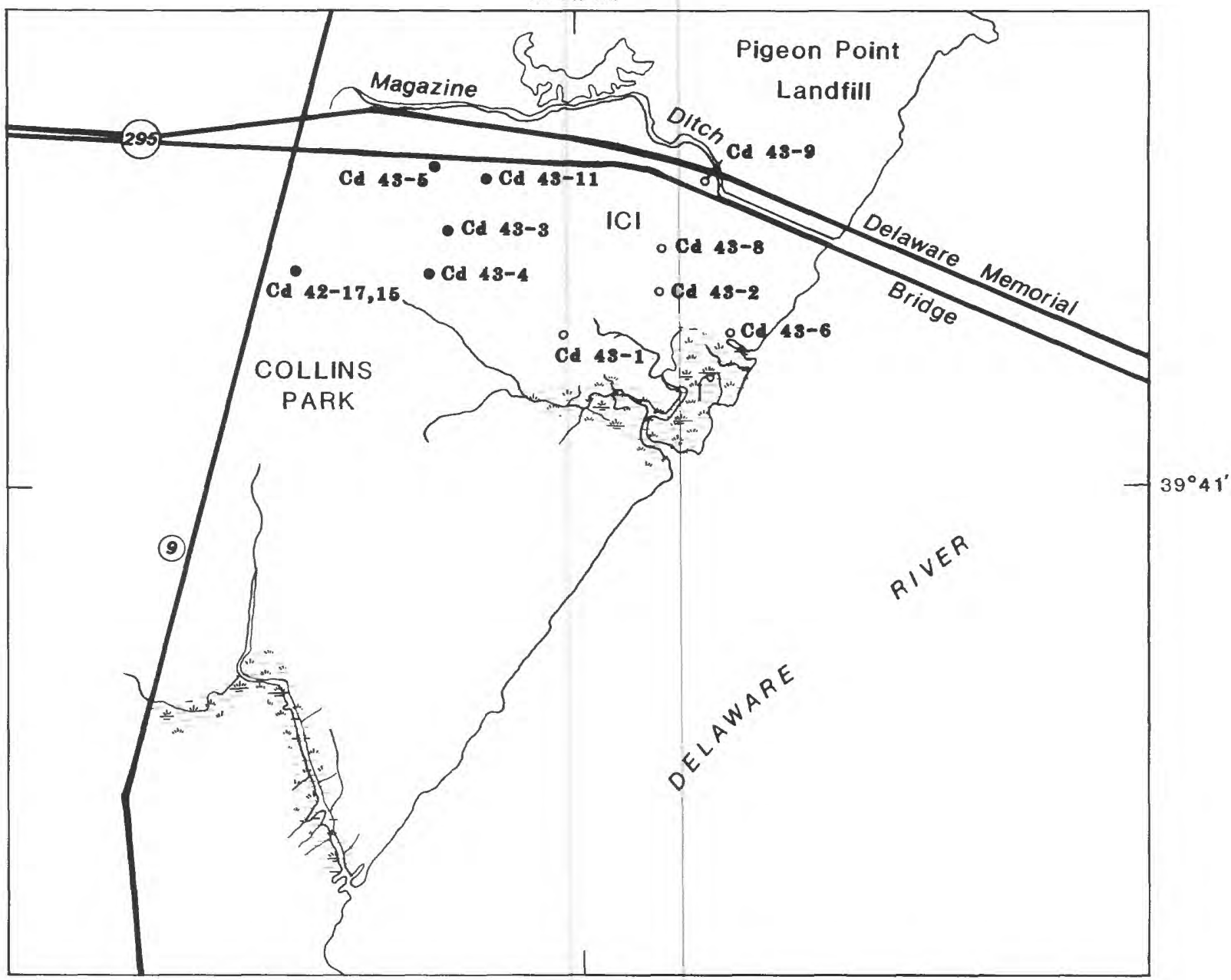

BASE MODIFIED FROM U.S. GEOLOGICAL SURVEY, 1:24,000 WILMINGTON SOUTH, DEL.-N.J. QUADRANGLE

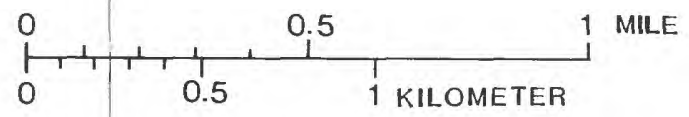

\section{EXPLANATION}

Cd 4-5. Well location and number in the middle Potomac aquifer

Cd 3-2. Well location and number in the Columbia aquifer.

Figure 24. Location of production wells in the middle Potomac and Columbia aquifers, at Collins Park and ICI Americas well fields. 
Chloride concentrations in wells Cd43-1 and Cd43-2 rose during the 1940's. In the 1940's, well Cd43-9 also had an elevated chloride concentration (table 4). Wells Cd43-6 and Cd43-8 had chloride concentrations from 21 to $56 \mathrm{mg} / \mathrm{L}$. The wells with the highest chloride concentrations have the shallowest screen settings (table 4), indicating that leakage from the overlying tidal marshes has occurred. Infiltration of this brackish water caused these wells to be abandoned in the late $1940^{\prime} \mathrm{s}$.

New wells were drilled between 1949 and 1952 west of the ICI plant and were screened in the middle Potomac aquifer. All of these wells, except Cd43-5, are presently (1987) still in use. Figure 25 shows the historical trends of chloride concentrations in these wells. Rasmussen and others (1957, p. 171) attributed higher chloride concentrations in 1955-56 to infiltration of water from the tidal drainage ditch (Magazine Ditch) just north of the well field, because the highest chloride concentrations were found closest to the ditch. The chloride increase could also reflect higher salinities in the tidal ditch resulting from the drought of the mid-1950's. Chloride concentrations showed another dramatic increase from 1965 through 1967, which coincides with elevated river salinity during the mid-1960's drought. An aquifer test performed by the U.S. Geological Survey during July 22-28, 1958, confirmed that recharge to the well field was from the tidal ditch and marsh to the north, as well as from the marsh to the east. The aquifer test also revealed the ICI well field is hydraulically connected to the Collins Park well field just to the west. Withdrawals of $1.5 \mathrm{Mgal} / \mathrm{d}$ in the ICI we11 field from 1967 to 1975 increased chloride concentrations in the production wells to 250 to $1,100 \mathrm{mg} / \mathrm{L}$. After 1975 , pumpage was reduced and chloride concentrations declined to 65 to $207 \mathrm{mg} / \mathrm{L}$ in May 1985. Figure 26 shows chloride concentrations at Collins Park during 1973-85. Concentrations rose from $30 \mathrm{mg} / \mathrm{L}$ in 1973 to $84 \mathrm{mg} / \mathrm{L}$ in 1985 . This demonstrates that the reduced pumpage at the ICI well fields caused the hydraulic gradients to change, possibly causing some flow towards the Collins Park well field.

Drilling of boreholes Cd44-16 and Cd53-1 provided data on the sediments underlying the river near ICI and Collins Park well fields and water levels and water quality of the underlying aquifers. These data indicate:

1. The Potomac confining unit underlying the river has been extensively eroded and replaced with sand and gravel of the Columbia Group (fig. 8). The overlying Holocene silt is only 15 to $20 \mathrm{ft}$ thick (fig. 10).

2. The Columbia aquifer is continuous onshore and under the Delaware River in this area. Thus, the Columbia aquifer becomes confined beneath the river. Water levels measured in the aquifer under the river in 1985 were 6 and $3 \mathrm{ft}$ below sea level in wells Cd44-16 and Cd53-1, respectively. The chloride concentrations were 290 and $400 \mathrm{mg} / \mathrm{L}$ in these wells.

3. Stiff and Durov plots of analyses of water from we1ls Cd53-1, Cd44-16, Cd43-4 (ICI), and Cd42-17 (Collins Park) show a very strong similarity to brackish water in the Delaware River (figs. 15 and 16). 


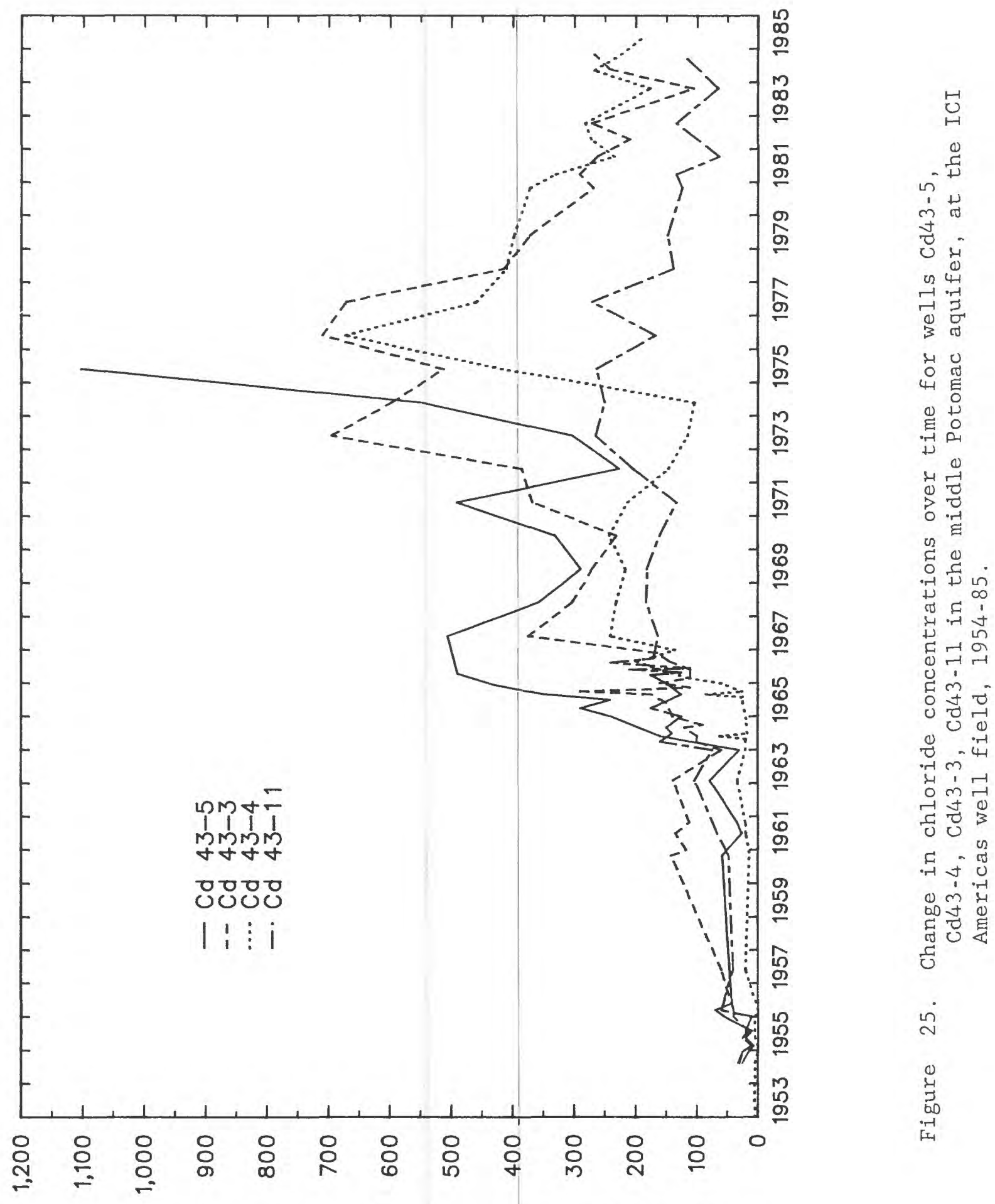

У $\exists \perp 17 \mathrm{y} \exists d$ SW 


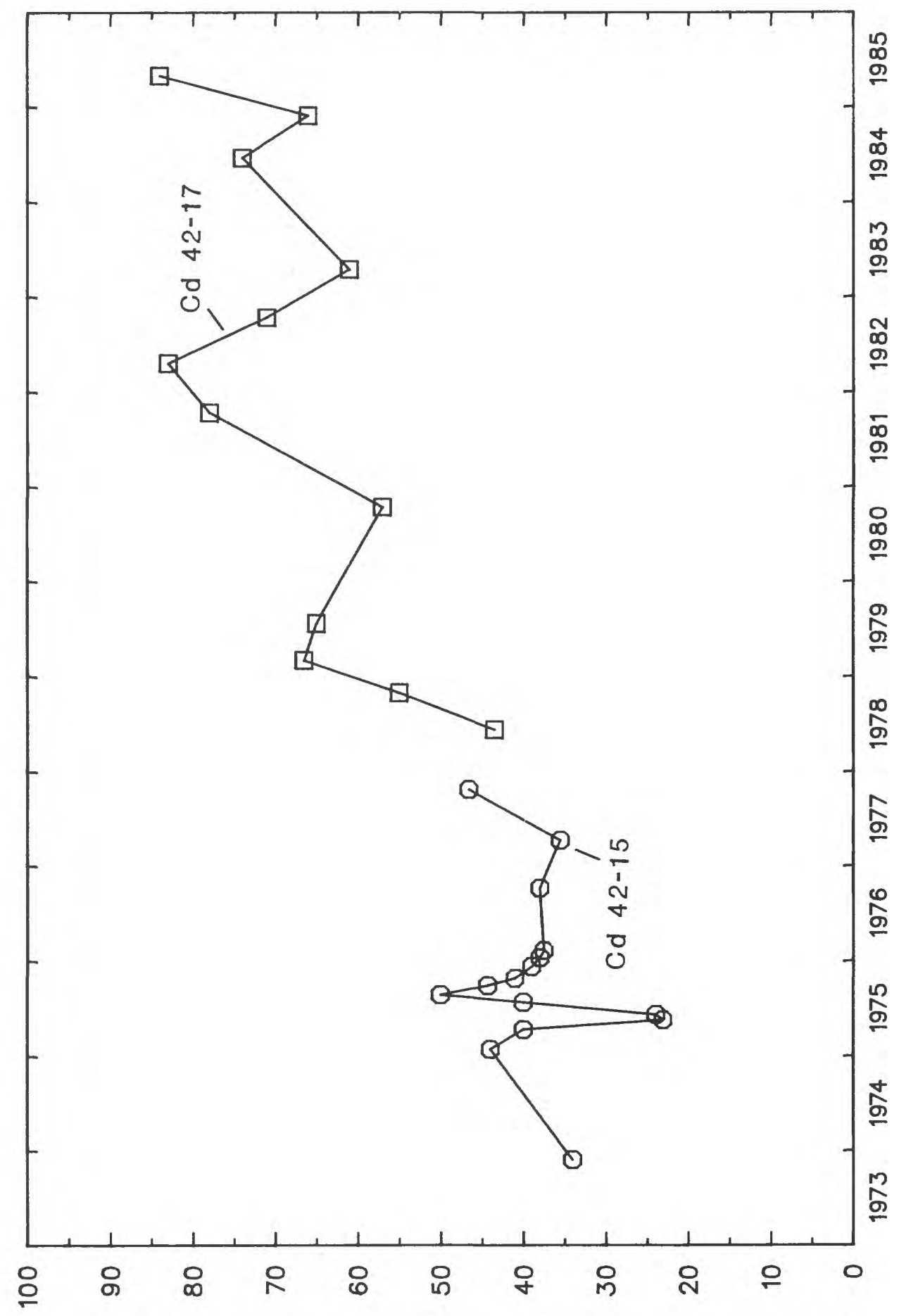

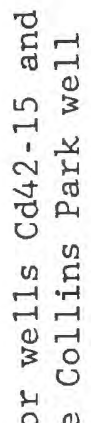

㐭

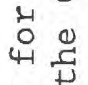

官

.

मi 4

$>4$

ज

ज ซ

.

岱

표

岃

동

¿

임

ช

$\rightarrow$

-1 0

$\Rightarrow$

० E

कन ने

in

0 ने

잉

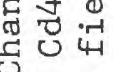

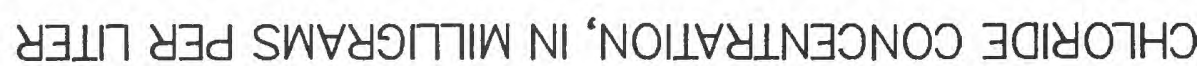


The data indicate that pumpage at the Collins Park and ICI well fields has caused water levels in the Columbia aquifer under the Delaware River to fall below sea level. As a result, brackish water infiltrates downward from the river. This water is drawn towards the cone of depression in the middle Potomac aquifer and enters the aquifer where the Potomac confining unit is thin or nonexistent. The result is increased chloride concentrations in the ICI and Collins Park well fields.

\section{SIMULATION OF INFILTRATION}

The preceding section presents field data documenting the occurrence of infiltration of river water into the Potomac aquifers. The flow model from the previous U.S. Geological Survey study (Martin, 1984) was used to help understand the effects and quantity of infiltration from the Delaware River into the Potomac aquifers. The objectives of the modeling effort were to (1) evaluate aquifer response to five different pumpage scenarios; (2) analyze the results of each scenario in order to estimate the amount of simulated infiltration of river water; and (3) study the potential effectiveness of a freshwater-injection barrier against the infiltration of river water.

\section{Digital Mode1}

Martin (1984, p. 14) used a computer program documented by Trescott (1975) to simulate flow within the Potomac aquifers. This program simulates the flow of ground water in three dimensions by using a finite-difference approximation to solve the ground-water flow equation. The flow model simulated aquifer pumpage from 1956 to 1980. The model was calibrated using steady-state and transient-state simulations. The input data used in the model developed by Martin (1984) were converted for use in the U.S. Geological Survey modular model (McDonald and Harbaugh, 1983) for this study.

\section{Conversion to the Modular Mode1}

Conversion of the previous model input data (Martin, 1984) to the U.S. Geological Survey modular model was done to provide the capability of studying cell by cell flow budgets in the vicinity of the Delaware River. The conversion involved reversing the layer numbers, renumbering the rows and columns, and reformatting the data sets from the previous model, such as, transmissivity, confining-unit leakance, storage, starting heads, grid spacing, stress period length, and pumpage. The conversion to the modular model did not change the boundary conditions, grid spacing, or aquifer properties used in the previous model.

The previous model simulated transient leakage from confining units, but the modular model does not have this capability. The transient calibration simulation based on heads (1956-80) was run with the modular model to determine the effect of reformatting data sets and not using transient leakage from confining units. Simulated head values in the study area from the modular model were within $1 \mathrm{ft}$ of previous model results. Therefore, the previous calibration done by Martin using the Trescott (1975) model was still valid for use in the newer modular model. 
A short discussion of conceptual framework, input data, and calibration of the model is provided. The reader should refer to Martin (1984) for a detailed discussion of these subjects.

\section{Model Description and Input Data}

The generalized hydrogeologic section and the schematic representation of the model layers and boundaries are shown in figure 27. The following discussion of the model description and input data is summarized from Martin (1984, p. 14-24). For the purpose of modeling, the Potomac Formation is divided into three layers (layers 2 to 4 ) with intervening confining units. The top model layer (layer 1) includes the Columbia aquifer and surfacewater bodies. The top layer is modeled as constant head and serves as a source of recharge to the underlying Potomac aquifers. Figure 27 shows a no-flow boundary between the constant head nodes (Columbia aquifer) and the active nodes in layers 2 and 3 (upper and middle Potomac aquifer). The purpose of the no-flow boundary is to direct all recharge from the Columbia aquifer downward into the Potomac aquifers, thus simulating natural conditions. This was done to prevent an unrealistic amount of recharge from the constant head nodes (Columbia aquifer) moving laterally into layers 2 and 3 (upper and middle Potomac aquifers). By simulating the downward flow of recharge, the amount of recharge can be controlled by adjusting the confining-unit leakance. The lower boundary of the model represents the top of the crystalline basement underlying the Coastal Plain sediments; it is considered a no-flow boundary.

The model grid spacing, lateral boundaries, and the area of the model used in this study are shown in figure 28. The northern boundary approximates the Fall Line and the limit of the Coastal Plain sediments in New Castle County. The eastern boundary in New Jersey approximates a groundwater discharge area and flow line as shown by Back (1966, fig. 3) and Luzier (1980, p. 46). This boundary is perpendicular to the Fall Line and intersects Camden, N.J. The western boundary approximates a similar discharge area in Maryland. The southern boundary roughly approximates the occurrence of $10,000 \mathrm{mg} / \mathrm{L}$ chloride concentrations within the Potomac Formation as shown by Meisler (1980, fig. 4). These four boundaries are modeled as no-flow boundaries. A detailed discussion concerning the assumptions and limitations of these boundary conditions can be found in Martin (1984, p. 25-26). Figure 28 also shows the study area in relation to the model grid.

Transmissivity arrays for each aquifer layer were used in the model. The final transmissivity values used in the model are available from Martin (1984, figs. 39, 40, and 41). In general, the transmissivities are lowest in the lower aquifer and highest in the upper aquifer. The maximum transmissivities of the lower, middle, and upper aquifer are 1,500, 3,500, and $6,000 \mathrm{ft}^{2} / \mathrm{d}$, respectively.

The confining units between the aquifers are represented in the model by assigning leakance values. Leakance values of the confining unit overlying the upper, middle, and lower Potomac aquifers are similar and range between $1 \times 10^{-1} \frac{3}{\mathrm{~s}}$ to $1 \times 10^{-7} / \mathrm{s}$ (Martin, 1984, p. 55). The highest 


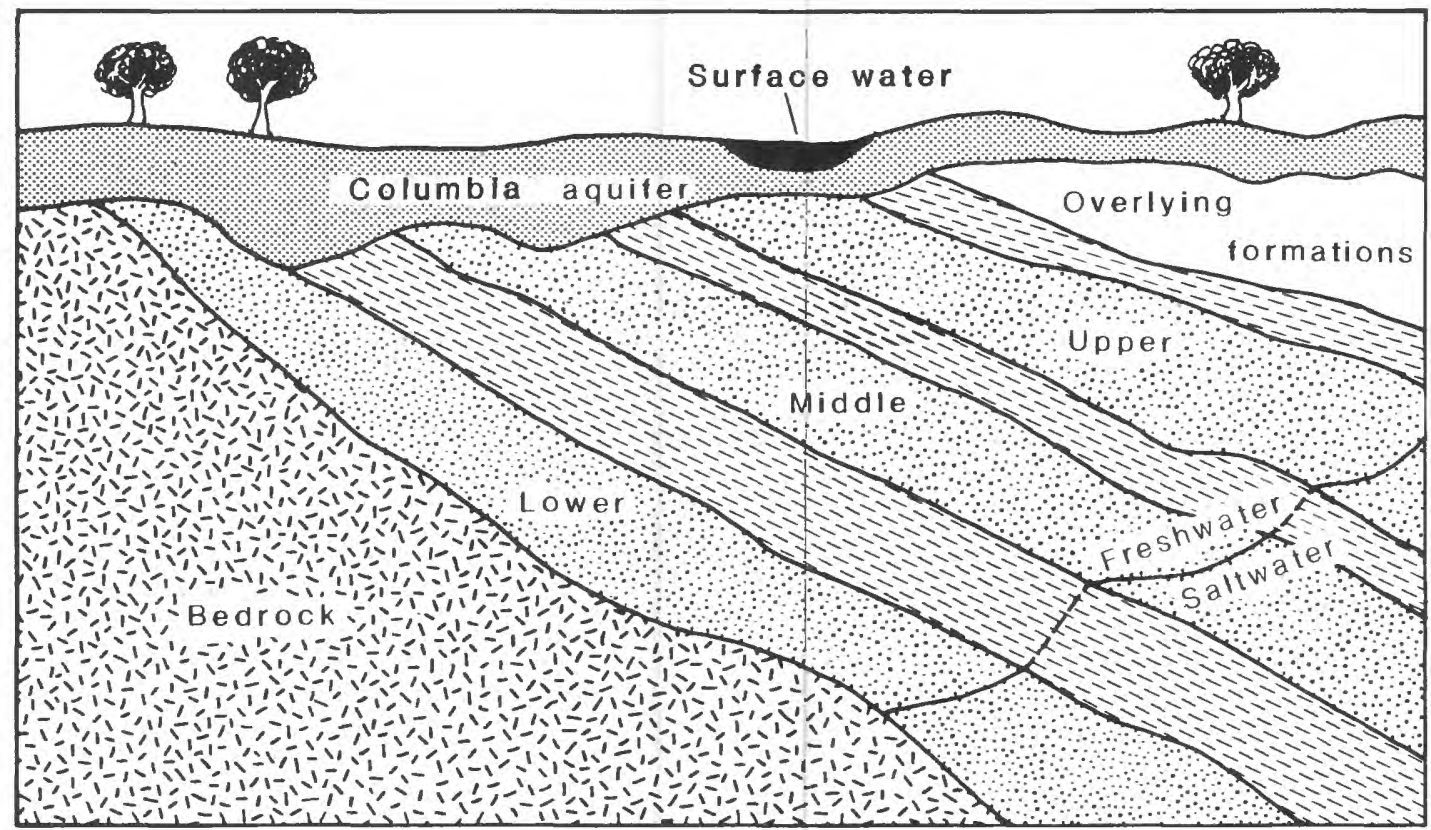

Potomac aquifer $\quad=-2$ Potomac confining unit

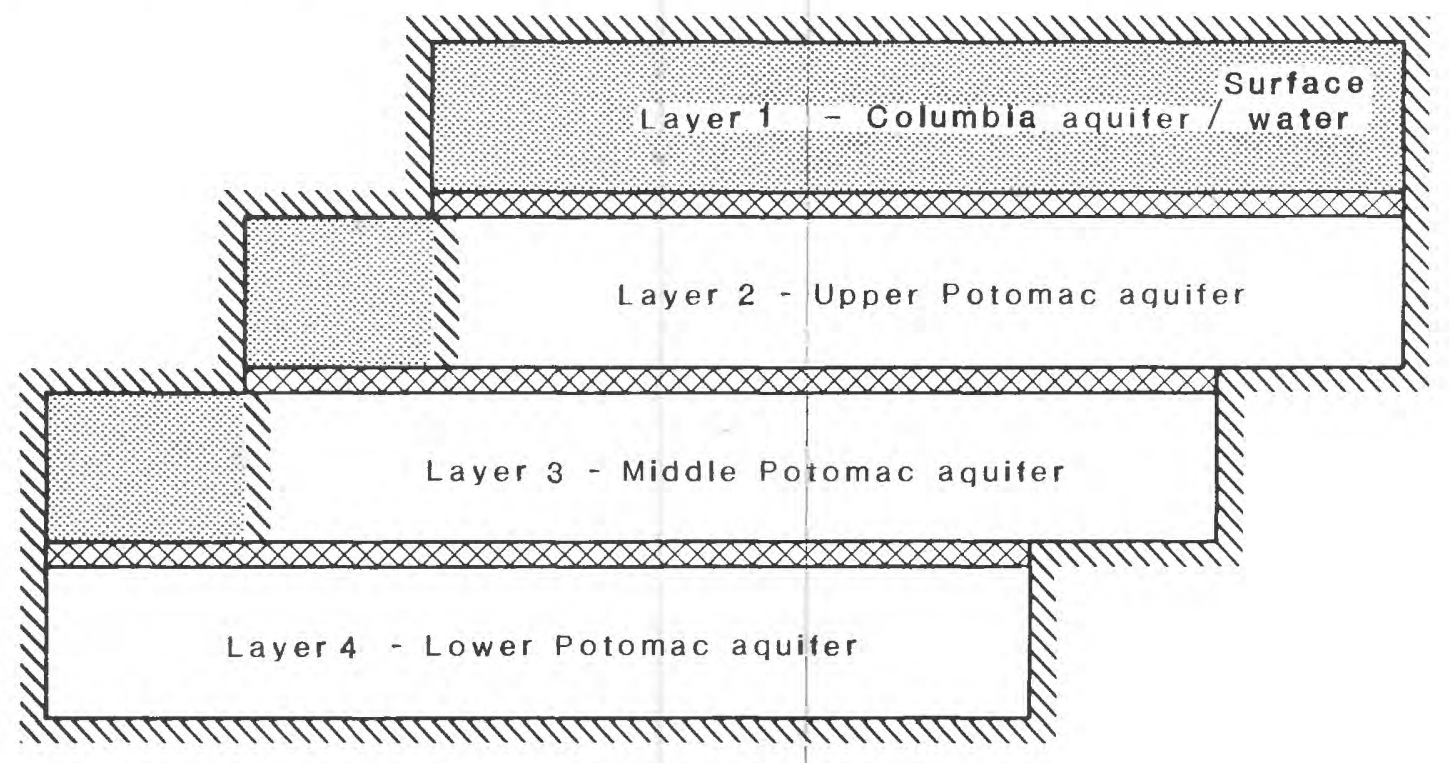

Figure 27. Generalized hydrogeologic section and schematic representation of model layers and boundaries. (Modified from Martin, 1984, fig. 11) 


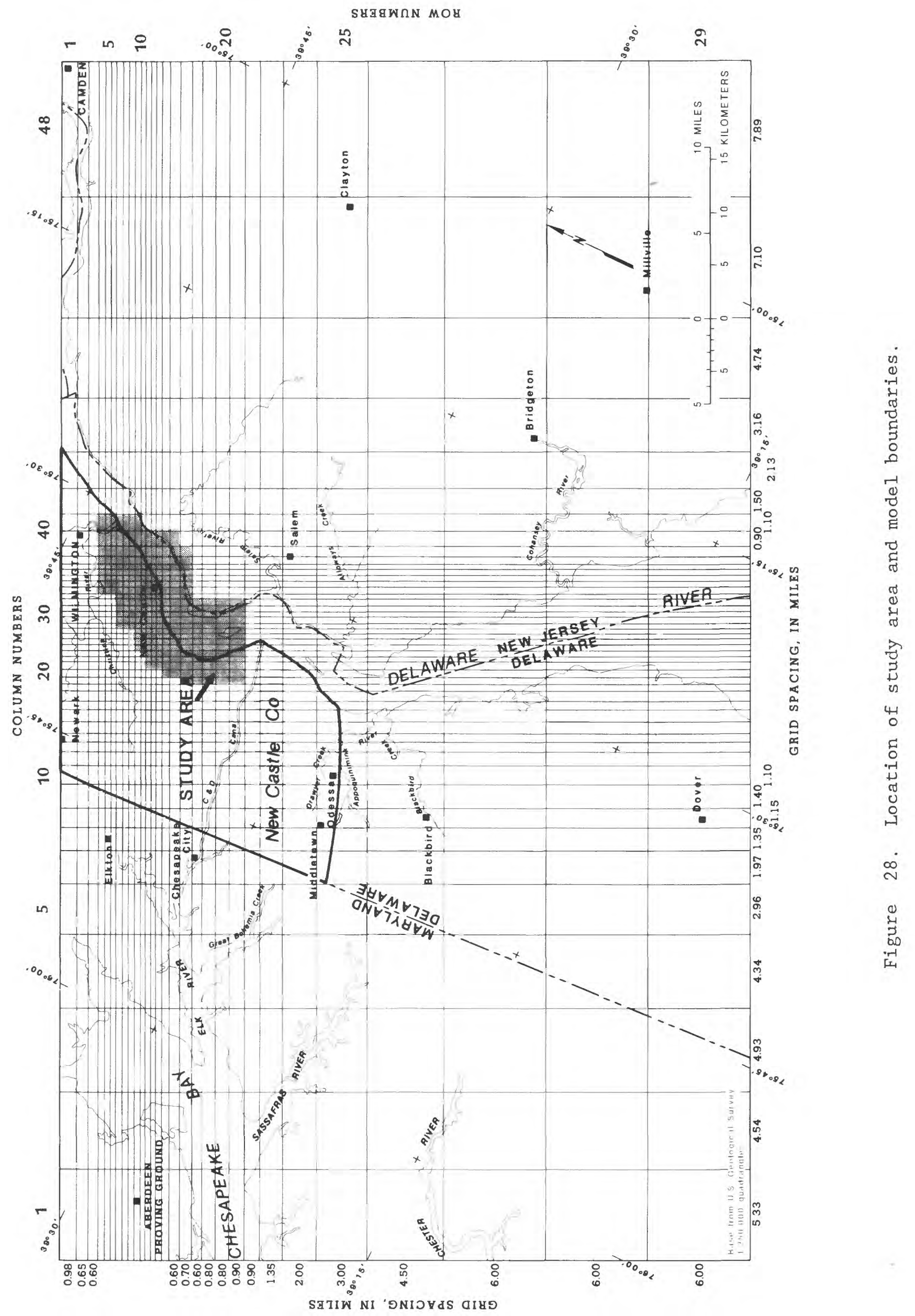


values and greatest range of values are in areas near the aquifer subcrops. In the model, the thickness of the confining unit overlying the uppermost Potomac aquifer includes the thickness of all the formations present between the Columbia aquifer and the uppermost Potomac aquifer (Martin, 1984, p. 15). However, the confining-unit leakance values underlying the river represent an average of the Holocene sediments, Columbia Group, and Potomac clay and silt. This is because the Columbia aquifer is not hydraulically connected with equivalent sediments underlying the river in much of the study area.

\section{Model Calibration}

The model was calibrated by simulating the ground-water flow system using the data described in the data input section and comparing the calculated heads and head changes to observed data. The calibration process for the model used in this study is provided by Martin (1984, p. 26-55). The calibration was a trial-and-error procedure. Hydraulic parameters of the aquifers and confining units were adjusted within an acceptable range until the model results simulated observed data reasonably well. Changes were made primarily in aquifer transmissivity and confining-unit leakance. The model was most sensitive to these latter parameters; that is, simulated heads varied greatest in response to changes in these parameters. Pumpage and the boundary conditions were considered to be known and were not changed during calibration.

Calibration included steady-state and transient-state simulations. Steady-state simulations were used to reproduce the flow system for a particular time when water levels were not changing and, therefore, storage in the aquifers or confining units had no effect on water levels. Transientstate simulations were used to model the transient response of the aquifers to changing pumpage from 1956 to 1980. Two types of transient simulations-one based on heads and one on drawdowns--were used for calibration. Transient calibration consisted of adjusting model inputs and comparing simulated well hydrographs to observed well hydrographs. For the calibration based on drawdown, comparisons were considered acceptable when the total difference between the calculated and observed head change was less than $1 \mathrm{ft} / \mathrm{yr}$ (foot per year), but not more than $10 \mathrm{ft}$ total difference over the period of observable data. The difference between the simulated and observed head changes for pumping periods 1 to 13 are 1 isted in Martin (1984, table 2). Calibration at the Artisans Village, Castle Hills, Collins Park and ICI well fields was considered unacceptable or uncertain (Martin, 1984, table 2). Because the transient simulation based on head changes could not reproduce water-level trends for 6 -month periods, a transient simulation based on heads was made to determine calibration acceptability. The model was considered to be calibrated if the October 1980 simulated heads were within 5 or $10 \mathrm{ft}$ of the observed heads, depending on the location of the wells. In general, relatively good comparison is seen between simulated and observed heads. 


\section{Effects of Hypothetical Pumpage Scenarios}

Five model simulations were run to evaluate aquifer response to pumpage scenarios. The amount of pumpage for each scenario was provided by DNREC. Results were analyzed in order to quantify the amount of simulated infiltration of river water. The model simulations were run under steady-state conditions. Martin (1984, p. 55) reported the modeled system (transient) approaches steady-state conditions rapidly following a change in pumpage. The transient calibration simulation (1956-80) was rerun under steady-state conditions with pumpage to test the validity of using this approach. The simulated heads from the model runs under both transient and steady-state conditions agreed within $1.0 \mathrm{ft}$.

Scenario 1 simulates the current pumping conditions (1985) in the aquifer system. The heads from the steady-state simulation with 1980 pumpage are used as starting heads for the first pumpage scenario. Table 5 lists the pumpage simulated for 1980 and the change in pumpage from 1980 for each scenario. The principal changes from the 1980 pumpage in the upper Potomac aquifer are the new production wells at the Artisans Village and Airport Industrial Park well fields, a decrease in production at the Crown Films well fields, and elimination of pumpage at the Amoco well field (table 5). Figure 29 is the simulated potentiometric surface in the upper Potomac aquifer for the first scenario. Production of $1.44 \mathrm{Mgal} / \mathrm{d}$ at the Artisans Village well field results in water levels from 35 to $45 \mathrm{ft}$ below sea level. The new stress at the Airport Industrial Park well field $(0.72 \mathrm{Mgal} / \mathrm{d})$ produces heads of $25 \mathrm{ft}$ below sea level. The elimination of pumpage at the Amoco well field and the decrease at the Crown Films well field results in a water level of about $25 \mathrm{ft}$ below sea level. Heads in the upper Potomac aquifer underlying the Delaware River are approximately 15 to $35 \mathrm{ft}$ below sea level.

The difference between simulated and observed heads in the upper Potomac aquifer can be seen by comparing figures 13 and 29 . Simulated and observed water levels are within $10 \mathrm{ft}$ at the Airport Industrial Park, Army Creek, Amoco, Crown Films, and National Guard well fields. Fairly good comparison is evident at the Artisans Village and Llangollen Estates well fields, except in the vicinity of the production wells. The discrepancy near the production wells is probably because the observed water level was measured at the well and the simulated water level represents an average value for the entire node. The $20-\mathrm{ft}$ difference in heads at the western New Castle well field reflects the boundary effects of the aquifer pinch out.

Figure 30 shows the simulated potentiometric surface of the middle Potomac aquifer for scenario 1. Simulated withdrawals in the middle Potomac aquifer in the vicinity of the Delaware River are from the ICI, Castle Hills, Jefferson Farms, and Collins Park well fields. The 1980 production at the eastern New Castle well field has been eliminated. Simulated water levels are between 40 and $50 \mathrm{ft}$ below sea level at the Collins Park and ICI well fields, and between 30 and $50 \mathrm{ft}$ below sea level at the Castle Hill and Jefferson Farms well fields. The water levels at the New Castle well field are about $25 \mathrm{ft}$ below sea level. Water levels in the area underlying the 
Table 5.--Location of wells and pumping rates used in simulated pumpage scenarios

\begin{tabular}{|c|c|c|c|c|c|c|c|c|c|}
\hline \multirow[b]{2}{*}{ Well field } & \multicolumn{3}{|c|}{ Node } & \multicolumn{6}{|c|}{ Pumpage, in million gallons per day } \\
\hline & Layer & Row & Column & 1980 & Scenario & $\underset{2}{\text { Scenario }}$ & $\underset{3}{\text { Scenario }}$ & $\underset{4}{\text { Scenario }}$ & Scenario \\
\hline Airport Industrial & 2 & 10 & 29 & 0 & 0.72 & 0.72 & 0.72 & 0.72 & 0.72 \\
\hline $\begin{array}{l}\text { Amoco } \\
\text { Amoco }\end{array}$ & $\begin{array}{l}2 \\
4\end{array}$ & $\begin{array}{l}13 \\
13\end{array}$ & $\begin{array}{l}29 \\
29\end{array}$ & $\begin{array}{r}0.47 \\
.41\end{array}$ & $\begin{array}{l}0 \\
0\end{array}$ & $\begin{array}{l}0 \\
0\end{array}$ & $\begin{array}{l}0 \\
0\end{array}$ & $\begin{array}{l}0 \\
0\end{array}$ & $\begin{array}{l}0 \\
0\end{array}$ \\
\hline $\begin{array}{l}\text { Army Creek } \\
\text { Army Crreek } \\
\text { Army crreek } \\
\text { Army Creek }\end{array}$ & $\begin{array}{l}2 \\
2 \\
2 \\
2\end{array}$ & $\begin{array}{l}12 \\
11 \\
12 \\
12\end{array}$ & $\begin{array}{l}27 \\
26 \\
26 \\
28\end{array}$ & $\begin{array}{l}.85 \\
.06 \\
.28 \\
.17\end{array}$ & $\begin{array}{l}.85 \\
.06 \\
.28 \\
.17\end{array}$ & $\begin{array}{l}.85 \\
.06 \\
.28 \\
.17\end{array}$ & $\begin{array}{l}0 \\
0 \\
0 \\
0\end{array}$ & $\begin{array}{l}.85 \\
.06 \\
.28 \\
.17\end{array}$ & $\begin{array}{l}.85 \\
.06 \\
.28 \\
.17\end{array}$ \\
\hline $\begin{array}{l}\text { Artisans village } \\
\text { Artisans village } \\
\text { Artisans vill lage }\end{array}$ & $\begin{array}{l}2 \\
\frac{2}{2} \\
2\end{array}$ & $\begin{array}{l}15 \\
15 \\
14\end{array}$ & $\begin{array}{l}22 \\
23 \\
22\end{array}$ & $\begin{array}{l}0 \\
0 \\
0\end{array}$ & $\begin{array}{l}.29 \\
1.15\end{array}$ & $\begin{array}{r}.56 \\
1.15 \\
.56\end{array}$ & $\begin{array}{r}.56 \\
1.15 \\
.56\end{array}$ & $1: 29$ & $\begin{array}{r}.56 \\
1.15 \\
.56\end{array}$ \\
\hline Castle Hills & 3 & 9 & 36 & 1.05 & .39 & 1.05 & 1.05 & 1.05 & 1.05 \\
\hline Collins Park & 3 & 8 & 38 & .39 & .39 & .39 & .39 & .39 & .39 \\
\hline Crown Films & 2 & 14 & 29 & .45 & .14 & .14 & .14 & .14 & .14 \\
\hline $\begin{array}{l}\text { ICI } \\
\text { ICI }\end{array}$ & $\frac{4}{3}$ & $\begin{array}{r}10 \\
9\end{array}$ & $\begin{array}{l}40 \\
39\end{array}$ & $0^{.28}$ & $\begin{array}{l}.28 \\
.28\end{array}$ & $\begin{array}{l}.28 \\
.28\end{array}$ & $\begin{array}{l}.28 \\
.28\end{array}$ & $\begin{array}{l}.28 \\
.28\end{array}$ & $\begin{array}{l}.28 \\
.28\end{array}$ \\
\hline Jefferson Farms & 3 & 9 & 35 & .80 & .80 & .80 & .80 & .80 & .80 \\
\hline $\begin{array}{l}\text { Llangol len Estates } \\
\text { Llangol len Estates }\end{array}$ & $\frac{2}{2}$ & $\begin{array}{l}14 \\
13\end{array}$ & $\begin{array}{l}26 \\
25\end{array}$ & 1.76 & $\begin{array}{l}.76 \\
1.05\end{array}$ & $\begin{array}{l}.76 \\
1.05\end{array}$ & $\begin{array}{l}2.31 \\
2.31\end{array}$ & 1.76 & $\begin{array}{l}2.31 \\
2.31\end{array}$ \\
\hline $\begin{array}{l}\text { New Castle } \\
\text { New Castle } \\
\text { New Castle }\end{array}$ & $\begin{array}{l}3 \\
2 \\
2\end{array}$ & $\begin{array}{l}12 \\
11 \\
10\end{array}$ & $\begin{array}{l}35 \\
32 \\
31\end{array}$ & $\begin{array}{l}.34 \\
.01 \\
.38\end{array}$ & $\begin{array}{l}0 \\
0.01 \\
.38\end{array}$ & $\begin{array}{l}0 \\
.01 \\
.38\end{array}$ & $\begin{array}{l}0 \\
.01 \\
.38\end{array}$ & $\begin{array}{l}0 \\
.01 \\
.38\end{array}$ & $\begin{array}{l}0 \\
.01 \\
.38\end{array}$ \\
\hline Tybouts Corner & 2 & 17 & 19 & 0 & 0 & 0 & 0 & .50 & .50 \\
\hline $\begin{array}{l}\text { Wilmington } \\
\text { Manor Gardens }\end{array}$ & $\frac{2}{2}$ & $\begin{array}{l}10 \\
10\end{array}$ & $\begin{array}{l}32 \\
33\end{array}$ & $\begin{array}{l}.22 \\
.42\end{array}$ & $\begin{array}{l}.22 \\
.42\end{array}$ & $\begin{array}{l}.22 \\
.42\end{array}$ & $\begin{array}{l}.22 \\
.42\end{array}$ & $\begin{array}{l}.22 \\
.42\end{array}$ & $\begin{array}{l}.22 \\
.42\end{array}$ \\
\hline
\end{tabular}

river are about $35 \mathrm{ft}$ below sea level. The simulated water levels are in close agreement with the observed water levels at the ICI and Collins Park well fields (fig. 14). About a 20 -ft difference exists between water levels at the Jefferson Farms, Castle Hills, and New Castle well fields. No other changes were made in pumpage for the middle Potomac aquifer in the other scenarios; therefore, only heads in the upper Potomac aquifer are discussed for scenarios 2 through 5 .

For scenarios 2 through 5, the simulated heads from the first scenario are used as starting heads. This allows analysis of changes from 1985 pumpage conditions. All simulations were run under steady-state conditions. Scenario 2 uses pumpage from scenario 1 and simulates increased production at the Artisans Village well field. The withdrawal of an additional 0.83 Mgal/d results in more than $15 \mathrm{ft}$ of drawdown in the well field and up to an additional $7 \mathrm{ft}$ of drawdown under the Delaware River (fig. 31) The resulting water level at Artisans Village is very close to the top of the upper Potomac aquifer (as shown in fig. 4).

Scenario 3 modifies pumpage of scenario 2. Pumpage is increased at the Llangollen Estates well field, while pumpage at the Army Creek recovery wells is eliminated (table 5). Production at the Llangollen Estates well 
field is increased to $4.62 \mathrm{Mgal} / \mathrm{d}$, which is the estimated maximum capacity of the well field. The additional withdrawals result in coalescing cones of depression between the Artisans Village and Llangollen Estates well fields. Figure 32 reveals drawdowns from 1985 levels of more than 25 and $35 \mathrm{ft}$ at these well fields, respectively. The resulting water level is below the top of the upper Potomac aquifer in the Artisans Village well field and within about $5 \mathrm{ft}$ at the Llangollen Estates well field.

Drawdowns of up to $18 \mathrm{ft}$ occur under the river. Elimination of the Army Creek recovery wells resulted in a $1-\mathrm{ft}$ rise in water levels in this well field. The combined effect of eliminating the Army Creek recovery wells and the additional pumpage at the Llangollen Estates well field results in a steeper hydraulic gradient from the Army Creek 1 andfill towards the Llangollen Estates well field. The increased pumpage at Llangollen Estates and Artisans Village also causes steeper gradient between the Delaware River and the well field.

Scenario 4 simulates aquifer response to a recovery well pumping 0.5 Mgal/d for the Tybouts Corner landfill. The well would be located just south of Red Lion Creek. This scenario uses pumpage from scenario 1 with the addition of the recovery well (table 5). Figure 33 reveals that more than $25 \mathrm{ft}$ of drawdown occurs at the recovery well site. Up to $15 \mathrm{ft}$ of drawdown occurs under Red Lion Creek and the Delaware River. The drawdown induces ground-water flow in the vicinity of the landfill away from the Artisans Village well field and towards the recovery well.

Scenario 5 combines the pumpage of scenarios 3 and 4 . This scenario simulates the maximum possible withdrawals of the well fields now in operation in the vicinity of the Delaware River. Aquifer response results in coalescing cones at the Llangollen Estates well field, Artisans Village weil field, and Tybouts Corner recovery well (fig. 34). Drawdowns are more than $40 \mathrm{ft}$ at the well fields and up to $22 \mathrm{ft}$ under the Delaware River. The resulting water levels are within $5 \mathrm{ft}$ of the top of upper Potomac aquifer. The increased pumpage would cause some flow to be diverted away from the Tybouts Corner recovery well and toward the Artisans Village well field and increase the hydraulic gradient from the river towards the aquifer.

\section{Simulated Quantity of Infiltration}

The ground-water flow model was used to quantify the amount of simulated infiltration of river water into the Potomac aquifers for each scenario. The approach taken to quantify infiltration rates was as follows:

1. The simulated flow patterns in the vicinity of the river were analyzed from the head maps of each pumping scenario.

2. We11 fields with coalescing cones of depression were considered as one pumping center.

3. The area of influence under the Delaware River was estimated for each pumping center based on the location of the simulated ground-water divides. 
4. Under steady-state conditions, outflow from the well field (pumpage) will equal inflow (recharge). The area of influence was divided into areas of (1) infiltration of river water, and (2) "freshwater" recharge on land to represent infiltration of river water as a percentage of total recharge to the well field.

5. The total amount of simulated infiltration of river water was calculated for the areas determined in number 3 above. This was the amount of flow between layer 1 (river) and layer 2 (upper Potomac aquifer) under the river.

6. The total pumpage of the composite well field was obtained from model input data.

7. The amount of infiltration of river water into the composite well field was represented as a percentage of total recharge by: (Total amount of infiltration/Total amount of pumpage) $\times 100=$ percentage of infiltration of river water as total recharge.

The amount and percentage of infiltration of river water was determined for the five pumpage scenarios and the 1980 steady-state calibration run. Table 6 lists the results of this analysis. In the upper Potomac aquifer, the Artisans Village, Llangollen Estates, Crown Films, and Amoco well fields were treated as a composite pumping center. Infiltration of river water into the upper Potomac aquifer in this area for the 1980 simulation accounts for 11.4 percent of the total recharge into the well field. The corresponding rate of infiltration of river water is $0.31 \mathrm{Mgal} / \mathrm{d}$ (table 6). For scenarios 1 through 5, infiltration into the upper Potomac aquifer ranged from 8.0 to 11.5 percent of total recharge (table 6). The range of percentages of infiltration of river water is small because increased infiltration of river water is balanced by increased freshwater recharge. However, the rate of infiltration of river water increases from $0.31 \mathrm{Mgal} / \mathrm{d}$ in the 1980 simulation to between 0.39 and $0.62 \mathrm{Mgal} / \mathrm{d}$ for scenarios 1 through 5 (table 6). The rate of infiltration for scenario 3, which simulates maximum production at the Artisans Village and Llangollen Estates well fields, and scenario 5, which includes pumpage of scenario 3 and the addition of the Tybouts Corner recovery we11, is about twice the 1980 simulation rate. A comparison of values in table 6 indicates there is a direct correlation between the rate of infiltration of river water and total well field pumpage.

The estimated area of infiltration into the upper Potomac aquifer under the Delaware River for each scenario is shown in figures 35 and 36 . Figure 35 indicates that the increase in pumpage from the 1980 simulation and scenario 1 almost doubles the area of infiltration in size. For scenarios 2 through 5 (fig. 36), the area of infiltration increases only slightly from scenario 1. Figures 35 and 36 suggest that the simulated area of infiltration of river water has reached its maximum with respect to simulated pumpage increases. Even though the area of infiltration has stabilized, the rate of infiltration still increases as pumpage is increased. 
Table 6.--Amount of infiltration of river water and well-field pumpage for simulated pumpage scenarios

$[\mathrm{Mgal} / \mathrm{d}=$ million gallons per day $]$

\begin{tabular}{lccc} 
& Total & Total & $\begin{array}{c}\text { Infiltration of } \\
\text { river water }\end{array}$ \\
$\begin{array}{l}\text { Scenario } \\
\text { and layer }\end{array}$ & infiltration & well field & as total well \\
& of river water & pumpage & field pumpage \\
& $($ Mgal $/$ d) & $($ Mgal $/ \mathrm{d})$ & (percent) \\
\hline
\end{tabular}

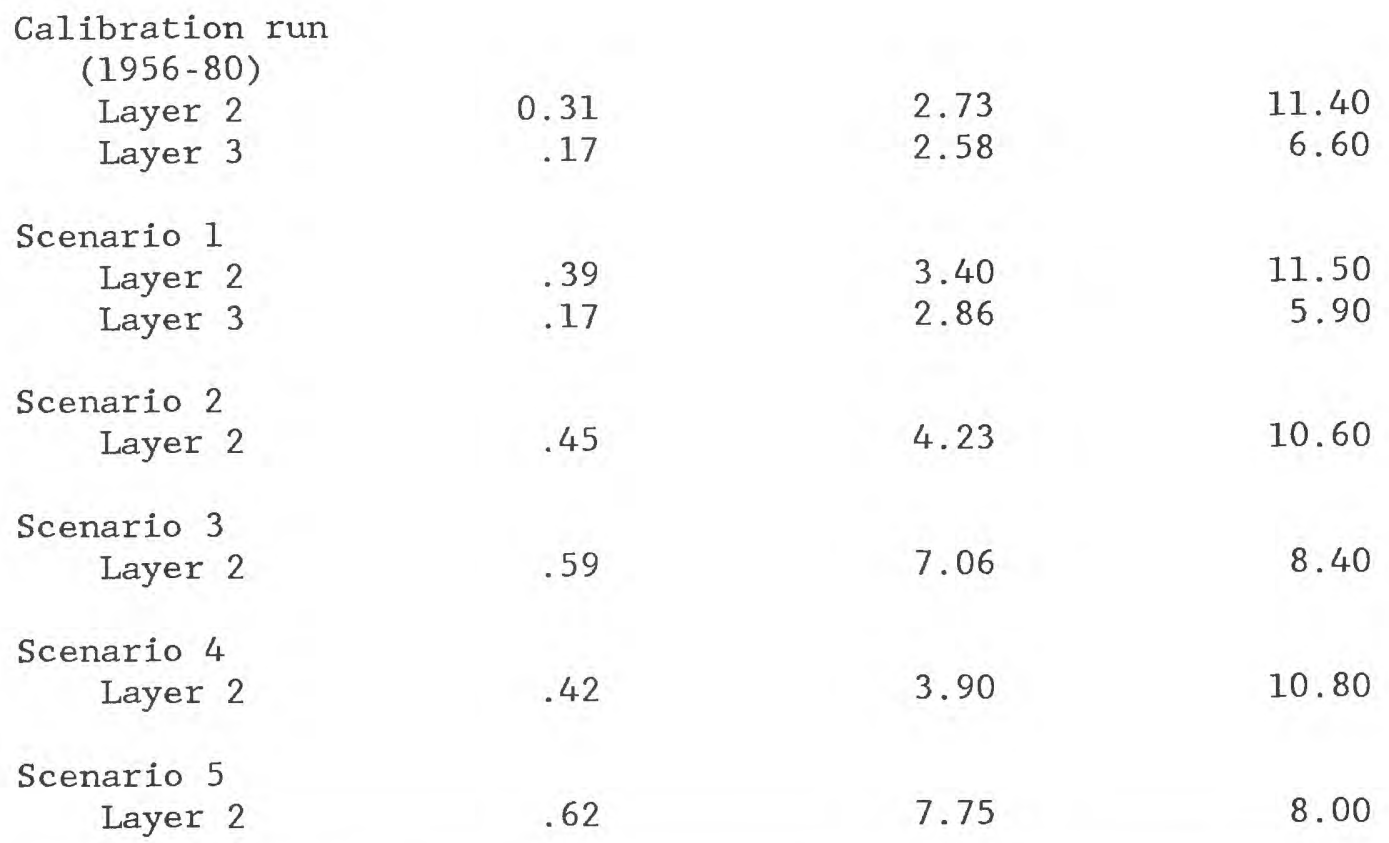

Leakance across the confining unit overlying the upper Potomac aquifer is shown in figure 37 . Leakance values range from $10^{-7} / \mathrm{d}$ to $10^{-5} / \mathrm{d}$ under the river in the area south of the town of New Castle. The distribution of the confining-unit leakance values in the model influences the amount of infiltration of river water into the aquifer. In each model scenario, most infiltration of river water occurs where ground-water levels are lowest and confining-unit leakance values are highest. The order of magnitude difference in leakance values causes a corresponding difference in the infiltration of river water.

An attempt was made to predict the chloride concentration in the upper Potomac aquifer using the percentages of simulated infiltration of river water. Table 2 lists the chloride concentrations in the sediments underlying the Delaware River. Between 36 and $98.5 \mathrm{ft}$ below sea level, chloride concentrations range between 152 to $894 \mathrm{mg} / \mathrm{L}$ for the Holocene silt and Potomac sediments. These concentrations were used as the possible range of chloride values of the brackish water at the point where it enters the 


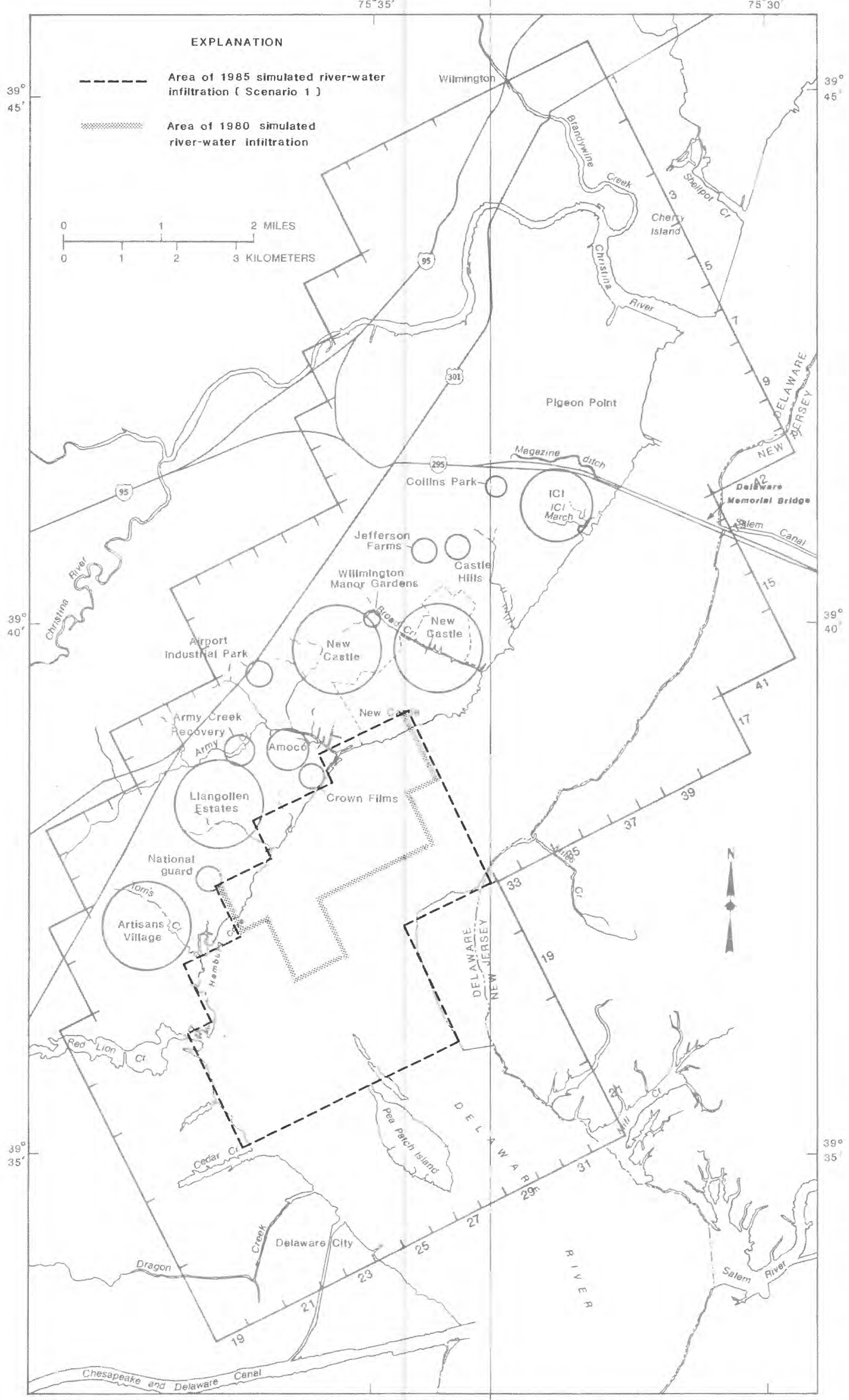

Figure 35. Area of simulated infiltration of river water into the upper Potomac aquifer near the Artisans Village, Llangollen Estates, and Crown Films well fields for steady-state calibration run (1980) and scenario 1 (1985 conditions). 


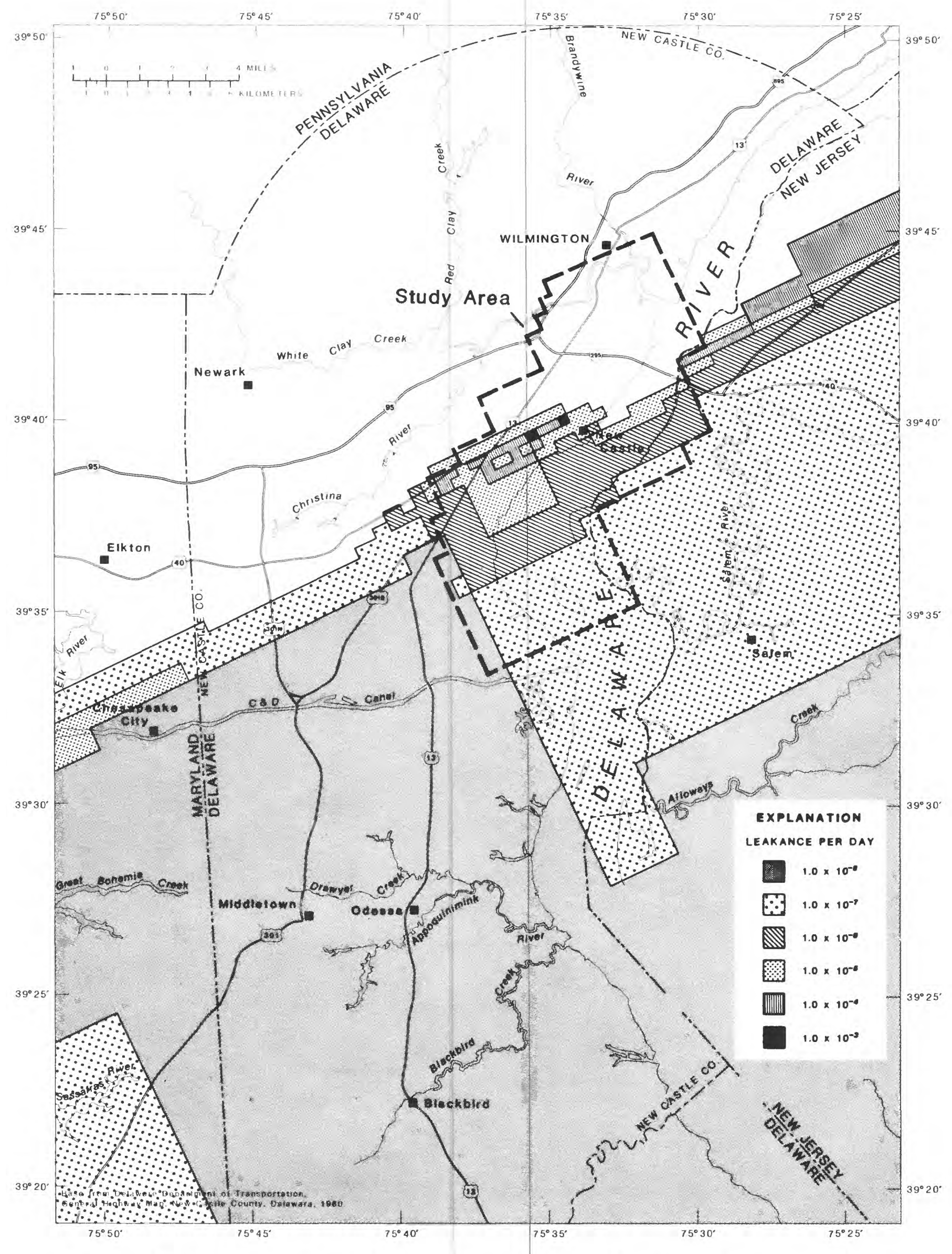

Figure 37. Leakance of confining unit overlying the upper Potomac aquifer. (Modified from Martin, 1984, fig. 42) 
aquifers. A background chloride concentration of $10 \mathrm{mg} / \mathrm{L}$ was assumed for the Potomac aquifer. Infiltration of river water accounts for about 8 to 11 percent of the total recharge into the upper Potomac aquifer. The mixing of river water and aquifer water can be represented by a mix of about one part river water (152 and $894 \mathrm{mg} / \mathrm{L}$ chloride) to nine parts aquifer water (10 $\mathrm{mg} / \mathrm{L}$ chloride). The resulting chloride concentrations range from 24 to $98 \mathrm{mg} / \mathrm{L}$. These are similiar to the values found in the upper Potomac aquifer near the Llangollen Estates, Crown Films, and Amoco well fields during 1985 (fig. 15).

In the middle Potomac aquifer, withdrawals from the New Castle, Collins Park, Castle Hills, and Jefferson Farms well fields were considered one pumping center. The ICI well fields were not simulated in the 1980 simulation, but were included in scenario 1. Table 6 indicates for the 1980 simulation and scenario 1 , the percentages of total recharge that is infiltration are 6.6 and 5.9, respectively. Figure 38 shows the area of infiltration of river water into the middle Potomac aquifer for each simulation. Leakance of the overlying confining units ranges from $10^{-7} / \mathrm{d}$ to $10^{-5} / \mathrm{d}$ ( $\mathrm{fig}$. 39). As in the upper Potomac aquifer, most of the infiltration of river water occurs where leakance is the highest and aquifer heads are the lowest.

A notable result of the infiltration analysis is that the percentage of total recharge that is river infiltration stays fairly constant during the pumpage scenarios. This is a function of the model conceptualization of the upper boundary condition. A constant-head boundary was used to simulate both the Columbia aquifer and the Delaware River. This boundary results in a constant source of recharge to the Potomac aquifer under different pumpage scenarios. The constant source of recharge caused the ratio of infiltration of river water and freshwater recharge to stay in relative balance under pumpage scenarios. In reality, there might not be a constant source of recharge from the Columbia aquifer under certain hydrologic conditions. For example, during low water table and high river stage conditions (if such ever occurs), the percentage of infiltration of river water would be higher. Because the Columbia aquifer is specified as constant head, the model cannot be used for simulating pumping or river infiltration into this aquifer.

Long-term average base flow can be used to represent the approximate amount of ground water available to recharge the Potomac aquifer under stressed conditions. Johnston (1977, p. 7) estimated annual recharge of 14 in. based on the average winter base flow of streams draining the unconfined aquifer in central and southern Delaware. Fleck (U.S. Geological Survey, written commun., 1986) simulated a base flow of about 13 in/yr in a model of the Coastal Plain sediments in Maryland and Delaware. If the potential capture of ground-water evapotranspiration is ignored, any ground water removed from the Columbia or Potomac aquifer by pumping from wells will eventually cause base flow to decrease proportionally. Sundstrom and Pickett (1971, p. 121) estimated the pumpage from the Columbia aquifer north of the Chesapeake and Delaware Canal to be about $2.3 \mathrm{in} / \mathrm{yr}$. If it is assumed that unstressed base flow is $14 \mathrm{in} / \mathrm{yr}$ (Johnston, 1977), then base flow under stressed unconfined aquifer conditions would be about 12 in/yr (14 in/yr minus 2 in/yr). This is probably a reasonable estimate of the maximum amount of ground water available to recharge the deeper Potomac aquifer unless the amount of pumpage in the Columbia aquifer changes. 


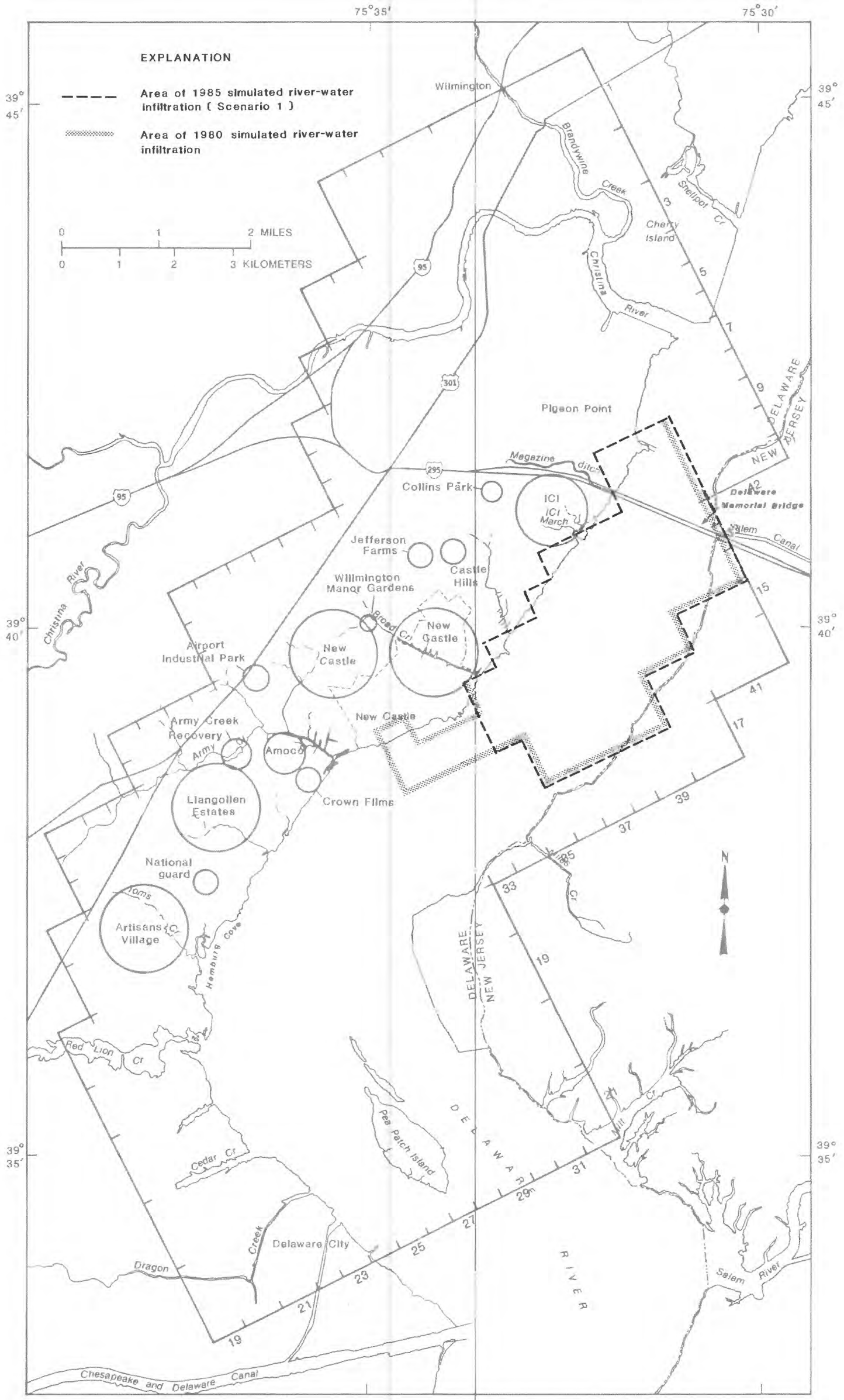

Figure 38. Area of simulated infiltration of river water into the middle Potomac aqui near the New Castle, Castle Hills, Jefferson Farms, Collins Park, and ICI Americas well fields for the steady-state calibration run (1980) and scenario 1 (1985 conditions). 


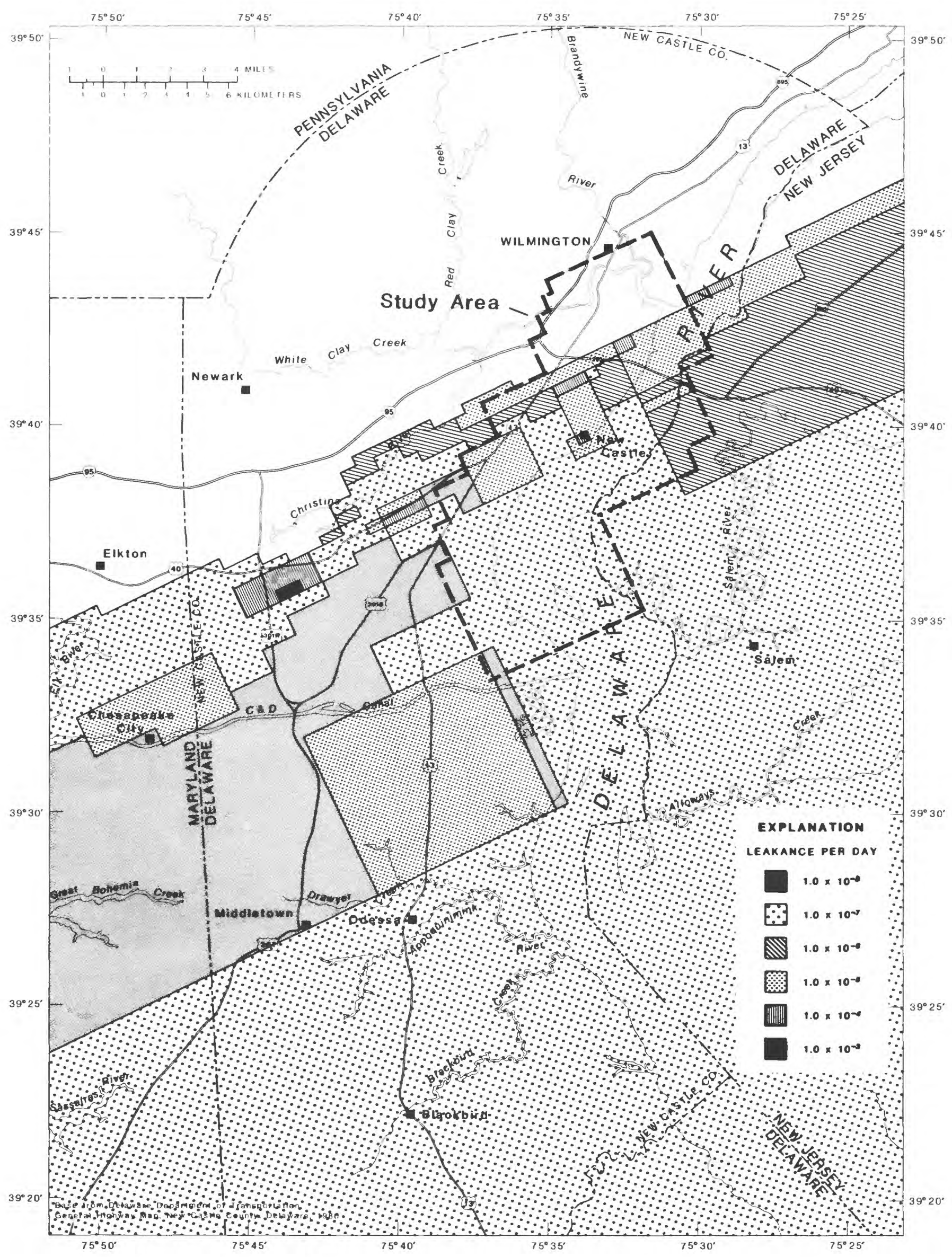

Figure 39. Leakance of confining unit overlying the middle Potomac aquifer: (Modified from Martin, 1984, fig. 43) 
Recharge from the Columbia aquifer to the Potomac aquifers under simulated 1980 pumping conditions is about $5 \mathrm{in} / \mathrm{yr}$. Under conditions of scenario 5 (maximum pumping), the simulated recharge from the Columbia aquifer is about $9 \mathrm{in} / \mathrm{yr}$. Assuming that $12 \mathrm{in} / \mathrm{yr}$ is the amount of ground water available for recharge (average base flow minus Columbia aquifer pumpage), it appears that the Columbia aquifer is capable of supplying sufficient freshwater recharge to the Potomac aquifers to balance the infiltration of river water, thereby maintaining the same relative percentages of total recharge in each scenario. However, even though the $5 \mathrm{in} / \mathrm{yr}$ of recharge under 1980 pumping conditions and the 9 in/yr of recharge under scenario 5 pumping conditions may be attainable, the associated effects may be severe. For example, in the case of scenario 5, long-term base flow would be reduced by about 75 percent (12 in/yr to 3 in/yr). Ground-water levels in the Columbia aquifer would decline accordingly. Moreover, under prolonged drought conditions during which there may be little or no recharge to the Columbia aquifer, base flow may cease altogether and dewatering of the Columbia aquifer could begin. Under these conditions, the percentage of total recharge that is river water would increase.

\section{SIMULATED EFFECT OF FRESHWATER-INJECTION BARRIERS}

One of the objectives of this study was to evaluate the effectiveness of a hypothetical freshwater injection barrier to reduce the infiltration of river water. Infiltration of river water into the upper Potomac aquifer is occurring near the Llangollen Estates, Crown Films, and Amoco well fields. Infiltration into the middle Potomac aquifer is taking place near the New Castle, Collins Park, and ICI well fields. Hydraulic gradients in these areas are from the Delaware River towards the underlying Potomac aquifers. Therefore, freshwater barrier wells would have to inject enough water to raise aquifer heads above sea level, thus resulting in flow from the aquifers towards the river.

Injection simulations were run using the scenario 1 (1985) pumpage conditions and starting heads. Simulations involving the upper Potomac aquifer consisted of 12 injection wells near the Artisans Village, Llangollen Estates, and Crown Films well fields (fig. 40). Simulated injection rates were 250,300 , and $500 \mathrm{gal} / \mathrm{min}$ (gallons per minute). Twelve wells injecting at $500 \mathrm{gal} / \mathrm{min}$ cause water levels to recover to 20 to $30 \mathrm{ft}$ above sea level in the injection well area. Aquifer heads under the Delaware River between Red Lion Creek and New Castle also are above sea level (up to $27 \mathrm{ft}$ above sea leve1). The next simulation uses 50 percent of the pumpage from the first simulation, which is $250 \mathrm{gal} / \mathrm{min}$. Water levels in the injection well area range from $5 \mathrm{ft}$ below sea level to $2 \mathrm{ft}$ above sea level. Water levels underlying the river are between 0 and $10 \mathrm{ft}$ below sea level. Thus, gradients are still from the river towards the aquifer in this simulation. Figure 40 shows the locations of the simulated injection wells and demonstrates the results of using a pumping rate of $300 \mathrm{gal} / \mathrm{min}$. Water levels in the injection well area are up to $20 \mathrm{ft}$ above sea level. Heads beneath the Delaware River adjacent to the injection wells are above sea leve1. Consequently, a minimum injection rate of $300 \mathrm{gal} / \mathrm{min}$ in each of the 12 wells is needed to maintain a freshwater injection barrier for the upper Potomac aquifer. 
Model runs with seven injection wells were used to simulate an injection barrier in the middle Potomac aquifer. The wells are located between the New Castle, Jefferson Farms, Castle Hills, ICI, and Collins Park well fields and the Delaware River. The injection-well simulations used a injection rate of $200 \mathrm{gal} / \mathrm{min}$. The simulated potentiometric surface is shown in figure 41. Water levels in the injection well area are up to $10 \mathrm{ft}$ above sea level, which provides a hydrologic barrier separating the well fields and the Delaware River. This is considered the least amount of injecttion necessary for the injection barrier.

\section{SUMMARY AND CONCLUSIONS}

This report evaluates the occurrence of brackish-water infiltration from the Delaware River into the underlying Potomac aquifers in northern Delaware. Three Potomac aquifers--the upper, middle, and lower--underlie the river. Pumpage from the aquifers has lowered aquifer heads below sea level, creating a hydraulic gradient from the Delaware River toward the Potomac aquifers.

In the vicinity of the Delaware River, the Potomac aquifers are overlain by a confining unit consisting of Potomac clay and silt, which acts as a barrier to the infiltration of river water. The downcutting of river channels during Pleistocene time resulted in partial erosion of the Potomac confining unit and the deposition of sand, gravel, and silt during Pleistocene and Holocene time. These sediments exhibit a greater permeability than the Potomac confining unit; therefore, the paleochannels can act as conduits for the infiltration of river water into the Potomac aquifers. The potential for infiltration of river water into the Potomac aquifers is suggested by ground-water levels below sea level and removal by erosion of confining units overlying the aquifer near the river. Evidence of the infiltration of river water actually occurring includes chloride concentrations in the aquifer above ambient levels and similarity in the chemical characteristics of the aquifer and river water.

Water quality of the uppermost Potomac aquifer is variable. Ambient ground-water chloride concentrations range from 10 to $21 \mathrm{mg} / \mathrm{L}$; specific conductance ranges from 100 to $225 \mu \mathrm{S} / \mathrm{cm}$. Plots of chemical analyses on Stiff and Durov diagrams reveal that the hydrochemical facies of the ambient ground water is sodium magnesium calcium-chloride sulfate bicarbonate type. Some areas in the aquifer have chloride concentrations of 40 to $8,600 \mathrm{mg} / \mathrm{L}$ and specific conductance of 200 to $27,200 \mu \mathrm{s} / \mathrm{cm}$. Chemical analyses of these latter areas indicate that the water is a sodium chloride type. Groundwater quality has been degraded by infiltration from the Delaware River and by leachate from waste-disposal sites. The sources of degradation were differentiated by using plots of major ion distributions, concentrations as a function of time, and geochemical plots including Stiff and Durov diagrams. 
Data indicate that infiltration of river water is occurring at the Llangollen Estates, Crown Films, and Amoco well fields in the upper Potomac aquifer. In 1985, chloride concentrations from the infiltration of river water ranged from 40 to $98 \mathrm{mg} / \mathrm{L}$ in these well fields. The eastern New Castle, ICI, and the Collins Park well fields in the middle Potomac aquifer have been affected by infiltration. Chloride concentrations in these well fields ranged from 61 to $207 \mathrm{mg} / \mathrm{L}$ in 1984 and 1985 . Two wells just south of the Wilmington Marine Terminal in the lower Potomac aquifer have been affected by infiltration. Leachate from the waste-disposal sites has caused localized ground-water degradation in all three Potomac aquifers, especially north of the Memorial Bridge and at sites near Army Creek and Red Lion Creek. Chloride concentrations up to $8,600 \mathrm{mg} / \mathrm{L}$ have resulted from wastedisposal leachate.

A ground-water flow model of the Potomac aquifers was used to simulate five pumpage scenarios to analyze aquifer response to projected future stresses. The results were analyzed to quantify the amount of simulated infiltration of river water for each scenario and to evaluate the feasibility of using freshwater injection barriers to protect the aquifers.

Scenario 1 simulated 1985 pumpage conditions. The principal changes from the 1980 pumpage in the upper Potomac aquifer are the new production wells at Artisans Village, ICI, and Airport Industrial Park well fields, a decrease of production at the Crown Films well field, and the elimination of pumpage at the Amoco and eastern New Castle, well fields. Water levels at the new well fields are 25 to $45 \mathrm{ft}$ below sea level. Water levels at the Amoco, Crown Films, and New Castle well fields are about $25 \mathrm{ft}$ below sea level. Scenario 2 simulated additional pumpage at the Artisans Village well field; pumpage resulted in a $15-\mathrm{ft}$ drawdown. Scenario 3 simulated pumpage from scenario 2 and simulated production of $4.62 \mathrm{Mgal} / \mathrm{d}$ at the Llangollen Estates well field and shut down of the Army Creek recovery wells. Drawdowns of more than 25 and $35 \mathrm{ft}$ could occur|at the Artisans Village and Llangollen Estates well fields, respectively, and a 1 -ft recovery could occur at the Army Creek recovery wells. Scenario 4 simulated pumpage from scenario 1 and a recovery well $(0.5 \mathrm{Mgal} / \mathrm{d})$ at the Tybouts Corner landfill. The production could cause a drawdown of $25 \mathrm{ft}$ and induce ground water towards the recovery well and away from Artisans Village. Scenario 5 combined the pumpage of scenarios 3 and 4; coalescing cones of depression formed between the Llangollen Estates, Artisans Village, and Tybouts Corner recovery wells.

The ground-water flow model is used to quantify infiltration of river water for the five pumpage scenarios and the calibration run (1956-80). In the upper Potomac aquifer, the Artisans Village, Llangollen Estates, Crown Films, and Amoco well fields are treated as a composite pumping center. Simulated infiltration of river water into the upper Potomac aquifer in this area ranges from 8.0 to 11.5 percent of total recharge to the well fields for the five scenarios. The rate of infiltration of river water increased from $0.31 \mathrm{Mgal} / \mathrm{d}$ for the 1980 simulation to $0.62 \mathrm{Mgal} / \mathrm{d}$ for scenario 5 (maximum pumpage). There is a direct correlation between the rate of infiltration of river water and total well-field pumpage. Infiltration into the middle Potomac aquifer near the New Casţle, Collins Park, Jefferson Farms, ICI, and Castle Hills well fields, is 6.6 and 5.9 percent of total recharge for the calibration run and scenario 1 , respectively. 
The ground-water flow model also was used to evaluate the aquifer response to using injection wells as a barrier to reduce the infiltration of river water. In the upper Potomac aquifer, 12 injection wells are simulated near the Artisans Village, Llangollen Estates, and Crown Films well fields. A minimum injection rate of $300 \mathrm{gal} / \mathrm{min}$ is needed to maintain a freshwater barrier for the upper Potomac aquifer. Seven wells located near the New Castle, Jefferson Farms, Castle Hills, ICI, and Collins Park well fields are used to simulate a freshwater injection barrier in the middle Potomac aquifer. A minimum injection rate of $200 \mathrm{gal} / \mathrm{min}$ is needed to prevent infiltration of river water in this area.

\section{REFERENCES}

Back, William, 1961, Techniques for mapping of hydrochemical facies, in Short papers in the geologic and hydrologic sciences: U.S. GeologicalSurvey Professional Paper 424-D, p. D380-D382.

1966, Hydrochemical facies and ground-water flow patterns in the northern part of the Atlantic Coastal Plain: U.S. Geological Survey Professional Paper 498-A, 42 p.

Baedecker, M. J., and Back, William, 1979, Hydrogeological processes and chemical reactions at a landfill: Groundwater, v. 17, no. 5, p. 429 437.

Baedecker, M. J., and Apgar, M. A., 1984, Hydrochemical studies at a landfill in Delaware, in Groundwater contamination: Natural Academy Press, Washington, D.C., p. 127-138.

Camp, Dresser, and McKee, 1982, Groundwater management plan for study area 1, Coastal Plain Formations: Consultant's report prepared by Camp, Dresser, and McKee, Inc., for the Delaware River Basin Commission, 52 p.

Chapelle, F. H., 1985, Hydrology, digital solute-transport simulations and geochemistry of the lower Cretaceous aquifer system near Baltimore, Maryland: Maryland Geological Survey Report of Investigations No. 43, $120 \mathrm{p}$.

Cohen, Bernard, 1957, Salinity of the Delaware estuary: U.S. Geological Survey Open-File Report, 86 p.

Cohen, Bernard, and McCarthy, L. T., 1963, Salinity of the Delaware estuary: U.S. Geological Survey Water-Supply Paper 1586-B, 47 p.

Duran, Philip, 1985, Distribution of bottom sediments and effects ofproposed dredging in the ship channel of the Delaware River between northeast Philadelphia, Pennsylvania, and Wilmington, Delaware, 1984: Hydrlogic Investigations Atlas HA-697, scale 1:24,000, 1 sheet. 
Durov, S. A., 1948, Klassifikacija prirodnych vod i graficeskoje izobrazenie ich sostava. [Classification of natural waters and graphic representation of their composition]: Doklady Ak. Nauk SSSR, v. 59, no. 1, p. 87-90.

Freeze, R. A. and Cherry, J. A., 1979, Groundwater: Englewood Cliffs, New Jersey, Prentice-Ha11, 604 p.

Geraghty and Miller, 1970, Occurrence of chlorides in the shallow artesian aquifer: Consultant's report prepared by Geraghty and Miller, Inc., for the Avisun Corporation, New Castle, Delaware, 21 p.

Gilbert/Commonwealth, 1981, Detailed site investigation of candidate sites for the Northern Solid Waste Facility: Consultant's report prepared by Gilbert/Commonwealth, Inc., for the Delaware Department of Natural Resources and Environmental Control, 65 p.

Groot, J. J., 1955, Sedimentary petrology of the Cretaceous sediments in Delaware in relation to paleographic problems: Delaware Geological Survey Bulletin 5, $157 \mathrm{p}$.

Henderson, Oliver, 1951, Chlorides in shallow well supply: MarylandDelaware Water and Sewage Association, 24th Annual Conference, Proceedings, p. 6-7.

Johnston, R. H., 1977, Digital model of the unconfined aquifer in central and southeastern Delaware: Delaware Geological Survey, Bulletin 15, 47 p.

Jordan, R. R., 1962, Stratigraphy of the sedimentary rocks of Delaware: Delaware Geological Survey Bulletin 9, 51 p.

1964, Columbia (Pleistocene) sediments of Delaware: Delaware Geological Survey Bulletin 12, 69 p.

1983, Stratigraphic nomenclature of nonmarine Cretaceous rocks in inner margin of Coastal Plain in Delaware and adjacent states: Delaware Geological Survey Report of Investigations No. 37, 46 p.

Jordan, R. R., and Groot, J. J., 1962, Some observations on the sediments of the Delaware River, south of Wilmington: Delaware Geological Survey Report of Investigations No. 6, $12 \mathrm{p}$.

Luzier, J. E., 1980, Digital-simulation and protection of head changes in the Potomac-Raritan-Magothy aquifer system, Coastal Plain, New Jersey: U.S. Geological Survey Water-Resources Investigations 80-11, 72 p.

Marine, I. W., and Rasmussen, W. C., 1955, Preliminary report on the geology and ground-water resources of Delaware: Delaware Geological Survey Bulletin 4, $336 \mathrm{p}$.

Martin, M. M., 1984, Simulated ground-water flow in the Potomac aquifers, New Castle County, Delaware: U.S. Geological Survey Water-Resources Investigations Report 84-4007, 85 p. 
Martin, M. M., and Denver, J. M., 1982, Hydrologic data for the Potomac Formation in New Castle County, Delaware: U.S. Geological Survey WaterResources Investigations Open-File Report 81-916, 148 p.

McDonald, M. G., and Harbaugh, A. W., 1983, A modular three-dimensional finite-difference ground-water flow model: U.S. Geological Survey OpenFile Report 83-875, 528 p.

McGee, W. J., 1886, Geological formations underlying Washington and vicinity: Report of the Health Officer of the District of Columbia for the year ending June 30,1885, p. 19-20; 23-25.

Meisler, Harold, 1980, Preliminary delineation of salty ground water in the Northern Atlantic Coastal Plain: U.S. Geological Survey Open-File Report 81-71, $37 \mathrm{p}$.

Miller, William, 1985, Remedial investigation--Delaware sand and gravel landfi11, Delaware: Dunn Geoscience Corporation, Latham, New York, $144 \mathrm{p}$.

Owens, J. P., and Minard, J. P., 1979, Upper Cenozoic sediments of the lowerDelaware Valley and the northern Delmarva Peninsula, New Jersey, Pennsylvania, Delaware, and Maryland: U.S. Geological Survey Professional Paper 1067-D, 47 p.

Rasmussen, W. C., Groot, J. J., Martin, R. 0. R., and others, 1957, The water resources of northern Delaware: Delaware Geological Survey Bulletin 6, v. 1, 223 p.

Reineck, H. E., and Singh, I. B., 1975, Depositional sedimentary environments: New York, Springer-Verlog, 439 p.

Stiff, H. A., Jr., 1951, The interpretation of chemical water analysis bymeans of patterns: Journal of Petroleum Technology, v. 3, no. 10. p. 15 to 17.

Spoljaric, Nenad, 1967, Pleistocene channels of New Castle County, Delaware: Delaware Geological Survey Report of Investigations No. 10, 15 p.

Sundstrom, R. W., 1974, Water resources in the vicinity of a solidwastelandfill in the Midvale-Llangollen Estates area, New Castle County,Delaware: University of Delaware, Water Resources Center, 92 p.

Sundstrom, R. W., and others, 1967, The availability of ground water from the Potomac Formation in the Chesapeake and Delaware Canal area, Delaware: University of Delaware, Water Resources Center, Newark, Delaware, $95 \mathrm{p}$.

Sundstrom, R. W., and Pickett, T. E., 1971, The availability of ground water in New Castle County, Delaware: University of Delaware, Water Resources Center, Newark, Delaware, 156 p. 
Talley, J. H., 1985, Geologic cross-section of Delaware River - Red Lion Creek to Killcahook National Wildlife Refuge: Delaware Geological Survey Miscellaneous Map No. 3.

Trescott, P. C., 1975, Documentation of finite-difference model for simulation of three-dimensional ground-water flow: U.S. Geological Survey Open-File Report 75-438, 103 p.

U.S. Environmental Protection Agency, 1976b, National interium primary drinking water regulations: Environmental Protection Agency-507/9-76003: Washington, D.C., U.S. Environmental Protection Agency Office of Water Supply

Weber, C. A., Young, S. P., and Apgar, M. A, 1985, Preliminary hydrological investigation of the Potomac aquifer underlying salt storage piles near I-495: Delaware Department of Natural Resources and Environmental Control, $21 \mathrm{p}$.

Woodruff, K. D., 1970, General ground-water quality in fresh-water aquifers of Delaware: Delaware Geological Survey Report of Investigtions No. 15, $22 \mathrm{p}$.

1985, Geohydrology of the Wilmington area, Delaware: Delaware Geological Survey, Hydrologic Map Series, Structural Geology, no. 3, sheet 4 , scale 1:24,000.

Woodruff, K. D., and Thompson, A. M., 1975, Geology of the Wilmington area, Delaware: Delaware Geological Survey, Geologic Map Series, no. 4, scale $1: 24,000$.

Zaporozec, Alexander, 1972, Graphical interpretation of water quality data: Ground Water, no. 10, p. 32-42. 